\title{
Werkgelegenheid en scholing 1996
}

Citation for published version (APA):

de Grip, A., van Smoorenburg, M. S. M., Borghans, L., \& Jonker, N. (1997). Werkgelegenheid en scholing 1996: Statistische Bijlage. Researchcentrum voor Onderwijs en Arbeidsmarkt, Faculteit der Economische Wetenschappen. ROA Reports No. 1B https://doi.org/10.26481/umarep.199701B

Document status and date:

Published: 01/01/1997

DOI:

10.26481/umarep.199701B

Document Version:

Publisher's PDF, also known as Version of record

\section{Please check the document version of this publication:}

- A submitted manuscript is the version of the article upon submission and before peer-review. There can be important differences between the submitted version and the official published version of record.

People interested in the research are advised to contact the author for the final version of the publication, or visit the DOI to the publisher's website.

- The final author version and the galley proof are versions of the publication after peer review.

- The final published version features the final layout of the paper including the volume, issue and page numbers.

Link to publication

\footnotetext{
General rights rights.

- You may freely distribute the URL identifying the publication in the public portal. please follow below link for the End User Agreement:

www.umlib.nl/taverne-license

Take down policy

If you believe that this document breaches copyright please contact us at:

repository@maastrichtuniversity.nl

providing details and we will investigate your claim.
}

Copyright and moral rights for the publications made accessible in the public portal are retained by the authors and/or other copyright owners and it is a condition of accessing publications that users recognise and abide by the legal requirements associated with these

- Users may download and print one copy of any publication from the public portal for the purpose of private study or research.

- You may not further distribute the material or use it for any profit-making activity or commercial gain

If the publication is distributed under the terms of Article $25 \mathrm{fa}$ of the Dutch Copyright Act, indicated by the "Taverne" license above, 


\title{
Werkgelegenheid en scholing 1996
}

\section{Statistische bijlage}

ROA-R-1997/1B

\author{
Andries de Grip \\ Michel van Smoorenburg \\ Lex Borghans \\ Nicole Jonker
}

Researchcentrum voor Onderwijs en Arbeidsmarkt

Faculteit der Economische Wetenschappen en Bedrijfskunde Universiteit Maastricht

Maastricht, januari 1997 
ISBN 90-5321-199-3

SEC 96740 


\section{Inhoud}

Voorwoord

Informatie naar bedrijfsgrootte

Tabel 1.1 Automatiseringsgraad naar bedrijfsgrootte,1993

Tabel 1.2 Percentage bedrijven met automatiseringspersoneel naar bedrijfsgrootte, 1993

Tabel 1.3 Automatiseringskosten per werknemer naar bedrijfsgrootte, 1993

Tabel 1.4 Gemiddelde R\&D-intensiteit en het aandeel bedrijven zonder R\&D-intensiteit naar bedrijfsgrootte, 1992

Tabel 1.5 Aandeel bedrijven met nieuwe en/of verbeterde produkten of diensten naar bedrijfsgrootte, 1992

Tabel 1.6 Aandeel bedrijven die octrooien hebben aangevraagd naar bedrijfsgrootte, 1992

Tabel 1.7 Opleidingsactiviteiten van bedrijven en instellingen naar bedrijfsgrootte, 1993

Tabel 1.8 Aantal opleidingen per werknemer, opleidingskosten in procenten van de arbeidskosten en opleidingskosten per werknemer naar bedrijfsgrootte, 1993

Informatie over bedrijfssectoren

Tabel 2.1 Automatiseringsgraad naar bedrijfssector, 1993

Tabel 2.2 Percentage bedrijven met automatiseringspersoneel naar bedrijfssector, 1993

Tabel 2.3 Automatiseringskosten per werknemer naar bedrijfssector, 1993

Tabel 2.4 Gemiddelde R\&D-intensiteit en het aandeel bedrijven zonder R\&D-intensiteit naar bedrijfssector, 1992

Tabel 2.5 Aandeel bedrijven met nieuwe en/of verbeterde produkten of diensten naar bedrijfssector, 1992

Tabel 2.6 Aandeel bedrijven die octrooien hebben aangevraagd naar bedrijfssector, 1992

Tabel 2.7 Ontwikkeling aantal werkenden naar bedrijfssector 1990-1994 en uitbreidingsvraag 1995-2000 (gemiddelde procentuele groei per jaar)

Tabel 2.8 Opleidingsactiviteiten van bedrijven en instellingen naar bedrijfstak/bedrijfsklasse, 1993

Tabel 2.9 Bedrijven en instellingen met trainingen op de werkplek 
en overige opleidingsactiviteiten naar bedrijfstak/

bedrijfsklasse, 1993

Tabel 2.10 Opleidingsactiviteiten van bedrijven en instellingen naar bedrijfstak/bedrijfsklasse, 1993

Tabel 2.11 Aantal opleidingen per werknemer, de opleidingskosten als percentage van de arbeidskosten en de opleidingskosten per werknemer naar bedrijfssector, 1990 en 1993

Tabel 2.12 Totale opleidingskosten en kosten per gevolgde opleiding naar bedrijfstak/bedrijfsklasse naar bedrijfssector, 1993

Tabel 2.13 Opleidingsactieve bedrijven en instellingen met een opleidingsbeleid voor specifieke groepen werknemers naar bedrijfssector, 1993

Tabel 2.14 Opleidingsactieve bedrijven en instellingen met een opleidingsbeleid voor ouderen naar bedrijfssector, 1993

Tabel 2.15 Opleidingsactieve bedrijven en instellingen met een opleidingsbeleid voor ongeschoolde of laaggeschoolde werknemers naar bedrijfssector, 1993

Informatie over beroepen

Tabel 3.1 Informatietechnologie naar beroepssegment 1993-1994

Tabel 3.2 Verwachte netto baancreatie naar beroepsklasse, 1995-2000 22

Tabel 3.3 Verwachte reallocatie naar beroepsklasse, 1995-2000 23

Tabel 3.4 Verwachte krimp-kengetallen voor beroepsklassen naar bedrijfssector, 1995-2000

Tabel 3.5 Oververtegenwoordiging ouderen (50-64) jaar ten opzichte van de andere werkenden naar beroepsklasse en opleidingsniveau, 199428

Tabel 3.6 Percentage werkenden dat tussen 1992-1994 een cursus heeft gevolgd naar beroepssegment

Tabel 3.7 Extra scholingsbehoefte (gezien de informatiseringsgraad) en extra omscholingsbehoefte (gezien de verwachte werkgelegenheidskrimp en sectorale reallocatie) naar beroepssegment

Tabel 3.8 Overzicht van perspectiefrijke omscholingsmogelijkheden naar beroepssegment

Risicoprofielen naar beroep

Informatie over opleidingen

Tabel 4.1 Informatietechnologie naar opleidingtype, 1993-1994

Tabel 4.2 Verwachte uitbreidingsvraag naar opleidingstype, 1995-2000

Tabel 4.3 Componenten van de werkgelegenheidsverschuivingen naar opleidingsniveau (netto effecten), 1995-2000

Tabel 4.4 Opleidingseffect naar opleidingstype, 1995-2000 (gemiddeld 
jaarlijks percentage)

Tabel 4.5 Verwachte krimp-kengetallen voor opleidingstypen naar

beroepssegment, 1995-2000

Tabel 4.6 Percentage werkenden dat tussen 1992-1994 een cursus heeft gevolgd naar opleidingstype

Tabel 4.7 Extra bijscholingsbehoefte (gezien de informatiseringsgraad) en extra omscholingsbehoefte (gezien de verwachte werkgelegenheidskrimp en sectorale reallocatie) per opleidingstype

Tabel 4.8 Overzicht van perspectiefrijke omscholingsmogelijkheden naar opleidingstype 



\section{Voorwoord}

Werkgelegenheid en scholing 1996 en deze bijbehorende Statistische bijlage is de eerste versie van een jaarlijks uit te brengen overzichtsrapport in het kader van het Werkgelegenheid en Scholing Observatorium (WSO) van het Researchcentrum voor Onderwijs en Arbeidsmarkt (ROA). Dit observatorium is door het Ministerie van Sociale Zaken en Werkgelegenheid ingesteld in het kader van de stimuleringsprogramma's ESF-4 Scholing voor behoud van werk en ADAPT van de Europese Commissie.

Het observatorium heeft als doel de voor het scholingsbeleid relevante marktontwikkelingen op continue basis in beeld te brengen. Het WSO fungeert daarbij als een centraal punt, waar de relevante ontwikkelingen en prognoses met betrekking tot de werkgelegenheid en kwalificatiebehoeften met elkaar in verband worden gebracht, om zo tijdig inzicht te krijgen in de scholingsactiviteiten binnen branches en bedrijven en de lacunes die op dit punt optreden.

Het observatorium-karakter van dit onderzoek wordt weerspiegeld door het grote aantal indicatoren dat de revue passeert. Deze kengetallen hebben telkens als doel opvallende factoren of ontwikkelingen te signaleren. Deze Statistische bijlage geeft een totaaloverzicht van de in het hoofdrapport besproken indicatoren voor alle onderscheiden bedrijfsgroottes, bedrijfssectoren, beroepen of opleidingen. In dit rapport wordt niet uitgebreid ingegaan op de methodiek die ten grondslag ligt aan de gepresenteerde indicatoren. Hierop wordt ingegaan in het werkdocument Methodiek werkgelegenheid en scholing 1996.

De projectleiding van het WSO is in handen van dr. A. de Grip. Daarnaast is aan het onderzoek meegewerkt door drs. M. van Smoorenburg, dr. L. Borghans en drs. N. Jonker. Onze dank gaat uit naar de leden van de begeleidingscommissie. Deze commissie bestaat uit de volgende leden: S.F.C. Claus, drs. M.G. Drewes, drs. F. Straatjes, drs. J.C. van der Velden, drs. J.A. Weisbeek. 
$\ldots \ldots$ 
INFORMATIE NAAR BEDRIJFSGROOTTE 
$\ldots \ldots$ 
Tabel 1.1

Automatiseringsgraad naar bedrijfsgrootte, 1993

\begin{tabular}{|c|c|c|c|}
\hline \multirow[t]{2}{*}{ Bedrijfsgrootte } & \multicolumn{2}{|c|}{$\begin{array}{c}\text { Automatiseringsgraad } \\
1993\end{array}$} & \multirow[t]{2}{*}{$\begin{array}{l}\text { Trend } \\
\text { 1989-'93 }\end{array}$} \\
\hline & $\%$ & typering & \\
\hline $\begin{array}{l}5-10 \text { werknemers } \\
10-20 \text { werknemers } \\
20-50 \text { werknemers } \\
50-100 \text { werknemers } \\
100-200 \text { werknemers } \\
200-500 \text { werknemers } \\
500 \text { of meer werknemers }\end{array}$ & $\begin{array}{l}69 \\
80 \\
90 \\
96 \\
97 \\
98 \\
98\end{array}$ & $\begin{array}{l}\text { erg laag } \\
\text { laag } \\
\text { gemiddeld } \\
\text { hoog } \\
\text { hoog } \\
\text { hoog } \\
\text { hoog }\end{array}$ & $\begin{array}{l}\text { stijgend } \\
\text { stijgend } \\
\text { stijgend } \\
\text { constant } \\
\text { constant } \\
\text { constant } \\
\text { constant }\end{array}$ \\
\hline Totaal & 78 & & stijgend \\
\hline
\end{tabular}

Bron: CBS 1995b/ROA

Tabel 1.2

Percentage bedrijven met automatiseringspersoneel naar bedrijfsgrootte, 1993

\begin{tabular}{lcll}
\hline Bedrijfsgrootte & $\begin{array}{l}\text { Percentage bedrijven met } \\
\text { automatiseringspersoneel 1993 } \\
\text { typering }\end{array}$ & $\begin{array}{l}\text { Trend } \\
\text { 1991-'93 }\end{array}$ & \\
\hline $5-10$ werknemers & 10 & laag & fluctuerend \\
$10-20$ werknemers & 9 & laag & fluctuerend \\
$20-50$ werknemers & 21 & gemiddeld & fluctuerend \\
$50-100$ werknemers & 34 & hoog & falend \\
$100-200$ werknemers & 59 & erg hoog & fluctuerend \\
$200-500$ werknemers & 71 & erg hoog & erg hoog \\
500 of meer werknemers & 89 & & fluctuerend \\
Totaal & 16 & & fluctuerend
\end{tabular}

Bron: CBS 1995b/ROA

Tabel 1.3

Automatiseringskosten per werknemer naar bedrijfsgrootte, 1993

\begin{tabular}{|c|c|c|c|}
\hline Bedrijfsgrootte & $\begin{array}{l}\text { Automati } \\
f\end{array}$ & $\begin{array}{l}\text { ten per werknemer } \\
1993 \\
\text { typering }\end{array}$ & $\begin{array}{l}\text { Trend } \\
\text { 1989-'93 }\end{array}$ \\
\hline $\begin{array}{l}5-10 \text { werknemers } \\
10-20 \text { werknemers } \\
20-50 \text { werknemers } \\
50-100 \text { werknemers } \\
100-200 \text { werknemers } \\
200-500 \text { werknemers } \\
500 \text { of meer werknemers }\end{array}$ & $\begin{array}{l}2.800,- \\
2.000,- \\
2.200,- \\
2.700,- \\
2.800,- \\
3.800,- \\
7.400,-\end{array}$ & $\begin{array}{l}\text { gemiddeld } \\
\text { laag } \\
\text { laag } \\
\text { gemiddeld } \\
\text { gemiddeld } \\
\text { gemiddeld } \\
\text { erg hoog }\end{array}$ & $\begin{array}{l}\text { dalend } \\
\text { dalend } \\
\text { constant } \\
\text { constant } \\
\text { fluctuerend } \\
\text { stijgend } \\
\text { stijgend }\end{array}$ \\
\hline Totaal & 4.300,-- & & constant \\
\hline
\end{tabular}

Bron: CBS 1995b/ROA 
Tabel 1.4

Gemiddelde R\&D-intensiteit en het aandeel bedrijven zonder R\&D-intensiteit naar bedrijfsgrootte, 1992

\begin{tabular}{|c|c|c|c|c|}
\hline & \multicolumn{2}{|c|}{$\begin{array}{l}\text { Gemiddelde R\&D- } \\
\text { intensiteit } \\
\% \text { typering }\end{array}$} & \multicolumn{2}{|c|}{$\begin{array}{l}\text { Percentage bedrijven } \\
\text { zonder R\&D } \\
\% \quad \text { typering }\end{array}$} \\
\hline $\begin{array}{l}10-19 \text { werknemers } \\
20-49 \text { werknemers } \\
50-99 \text { werknemers } \\
100-199 \text { werknemers } \\
200-499 \text { werknemers } \\
500 \text { en meer werknemers }\end{array}$ & $\begin{array}{l}0,4 \\
0,5 \\
1,4 \\
1,1 \\
1,4 \\
2,5\end{array}$ & $\begin{array}{l}\text { laag } \\
\text { laag } \\
\text { gemiddeld } \\
\text { gemiddeld } \\
\text { gemiddeld } \\
\text { erg hoog }\end{array}$ & $\begin{array}{l}96 \\
92 \\
80 \\
75 \\
58 \\
47\end{array}$ & $\begin{array}{l}\text { hoog } \\
\text { hoog } \\
\text { gemiddeld } \\
\text { gemiddeld } \\
\text { laag } \\
\text { erg laag }\end{array}$ \\
\hline Totaal & 1,6 & & 90 & \\
\hline
\end{tabular}

Bron: ESI-VU/ROA

Tabel 1.5

Aandeel bedrijven met nieuwe en/of verbeterde produkten of diensten naar bedrijfsgrootte, 1992

\begin{tabular}{|c|c|c|c|c|}
\hline & \multicolumn{2}{|c|}{$\begin{array}{l}\text { Aandeel bedrijven } \\
\text { met nieuwe } \\
\text { produkten voor het } \\
\text { bedrijf }\end{array}$} & \multicolumn{2}{|c|}{$\begin{array}{l}\text { Aandeel bedrijven } \\
\text { met nieuwe } \\
\text { produkten voor de } \\
\text { bedrijfstak }\end{array}$} \\
\hline & $\%$ & typering & $\%$ & typering \\
\hline $\begin{array}{l}10-19 \text { werknemers } \\
20-49 \text { werknemers } \\
50-99 \text { werknemers } \\
100-199 \text { werknemers } \\
200-499 \text { werknemers } \\
500 \text { en meer werknemers }\end{array}$ & $\begin{array}{l}15 \\
22 \\
40 \\
46 \\
59 \\
68\end{array}$ & $\begin{array}{l}\text { erg laag } \\
\text { laag } \\
\text { gemiddeld } \\
\text { gemiddeld } \\
\text { hoog } \\
\text { erg hoog }\end{array}$ & $\begin{array}{r}4 \\
6 \\
11 \\
17 \\
19 \\
31\end{array}$ & $\begin{array}{l}\text { laag } \\
\text { laag } \\
\text { gemiddeld } \\
\text { gemiddeld } \\
\text { gemiddeld } \\
\text { erg hoog }\end{array}$ \\
\hline Totaal & 23 & & 7 & \\
\hline
\end{tabular}

Bron: ESI-VU/ROA

Tabel 1.6

Aandeel bedrijven die octrooien hebben aangevraagd naar bedrijfsgrootte, 1992

Aandeel bedrijven met octrooien

$\% \quad$ typering

10-19 werknemers

20-49 werknemers

50-99 werknemers

100-199 werknemers

200-499 werknemers

500 en meer werknemers

laag

$\begin{aligned} 1 & \text { laag } \\ 2 & \text { laag } \\ 5 & \text { gemiddeld } \\ 8 & \text { gemiddeld } \\ 14 & \text { hoog } \\ 16 & \text { erg hoog }\end{aligned}$

Totaal

3

Bron: ESI-VU/ROA 
Tabel 1.7

Opleidingsactiviteiten van bedrijven en instellingen naar bedrijfsgrootte, 1993

\begin{tabular}{lcccc}
\hline & Totaal & $\begin{array}{l}\text { Interne of } \\
\text { externe } \\
\text { opleidingen } \\
\%\end{array}$ & $\begin{array}{l}\text { Trainingen } \\
\text { op de } \\
\text { werkplek } \\
\%\end{array}$ & $\begin{array}{l}\text { Overige } \\
\text { opleidings- } \\
\text { activiteiten } \\
\%\end{array}$ \\
\hline $5-99$ werknemers & 42 & 32 & 15 & 37 \\
$100-499$ werknemers & 87 & 84 & 38 & 80 \\
500 en meer werknemers & 100 & 100 & 62 & 86 \\
Totaal & 45 & 35 & 16 & 39 \\
\hline
\end{tabular}

Bron: CBS 1995a

Tabel 1.8

Aantal opleidingen per werknemer, opleidingskosten in procenten van de arbeidskosten en opleidingskosten per werknemer naar bedrijfsgrootte, 1993

\begin{tabular}{lccc}
\hline & $\begin{array}{c}\text { Aantal opleidingen } \\
\text { per werknemer }\end{array}$ & $\begin{array}{c}\text { Opleidingskosten } \\
\text { in \% van de } \\
\text { arbeidskosten } \\
\%\end{array}$ & $\begin{array}{c}\text { Opleidingskosten } \\
\text { per werknemer }\end{array}$ \\
\hline 5-99 werknemers & 0,18 & 0,7 & $f$ \\
100-499 werknemers & 0,40 & 1,3 & 380 \\
500 en meer werknemers & 0,52 & 3,0 & 1.750 \\
Totaal & 0,35 & 1,7 & 990 \\
\hline
\end{tabular}

Bron: CBS 1995a 
INFORMATIE OVER BEDRIJFSSECTOREN 

Tabel 2.1

Automatiseringsgraad naar bedrijfssector, 1993

\begin{tabular}{|c|c|c|c|}
\hline \multirow[t]{2}{*}{ Bedrijfssector } & \multicolumn{2}{|c|}{$\begin{array}{c}\text { Automatiseringsgraad } \\
1993\end{array}$} & \multirow[t]{2}{*}{$\begin{array}{l}\text { Trend } \\
\text { 1989-'93 }\end{array}$} \\
\hline & $\%$ & typering & \\
\hline $\begin{array}{l}\text { Delfstoffenwinning, ind. en openb. nutsbedr. } \\
\text { - Voedings- en genotmiddelenindustrie } \\
\text { - Textiel-, kleding- en lederindustrie } \\
\text { - Papier(waren)- en grafische industrie } \\
\text { - Aardolie-, chem. rubber en kunststofverw. ind. } \\
\text { - Metaal-en elektrotechnische industrie } \\
\text { - Overige industrie en delfstoffenwinning } \\
\text { - Openbare nutsbedrijven } \\
\text { Bouwnijverheid en bouwinstallatiebedrijven } \\
\text { - Bouwnijverheid } \\
\text { - Bouwinstallatiebedrijven } \\
\text { Handel } \\
\text { - Groothandel e.d. } \\
\text { - Detailhandel, horeca en reparatiebedrijven } \\
\text { Zakelijke dienstverlening } \\
\text { - Transport-, opslag- en communicatiebedrijven } \\
\text { - Bankwezen } \\
\text { - Verzekeringswezen } \\
\text { - Computerservice- en IT bureaus } \\
\text { - Overige zakelijke dienstverlening } \\
\text { Overige } \\
\text { - Onderwijs } \\
\text { - Gezondheids- en vet. diensten, ms. dienstverl. } \\
\text { - Overige dienstverlening } \\
\text { - Landbouw en visserij }\end{array}$ & $\begin{array}{l}81 \\
73 \\
67 \\
94 \\
96 \\
74 \\
90 \\
99 \\
71 \\
71 \\
72 \\
75 \\
90 \\
65 \\
82 \\
80 \\
67 \\
99 \\
82 \\
82 \\
78 \\
84 \\
87 \\
71 \\
69\end{array}$ & $\begin{array}{l}\text { gemiddeld } \\
\text { laag } \\
\text { laag } \\
\text { hoog } \\
\text { erg hoog } \\
\text { laag } \\
\text { hoog } \\
\text { erg hoog } \\
\text { laag } \\
\text { laag } \\
\text { laag } \\
\text { gemiddeld } \\
\text { hoog } \\
\text { erg laag } \\
\text { gemiddeld } \\
\text { gemiddeld } \\
\text { laag } \\
\text { erg hoog } \\
\text { gemiddeld } \\
\text { gemiddeld } \\
\text { gemiddeld } \\
\text { gemiddeld } \\
\text { hoog } \\
\text { laag } \\
\text { laag }\end{array}$ & $\begin{array}{l}\text { stijgend } \\
\text { stijgend } \\
\text { constant } \\
\text { stijgend } \\
\text { stijgend } \\
\text { constant } \\
\text { sterk stijgend } \\
\text { constant } \\
\text { stijgend } \\
\text { sterk stijgend } \\
\text { constant } \\
\text { stijgend } \\
\text { stijgend } \\
\text { stijgend } \\
\text { stijgend } \\
\text { sterk stijgend } \\
\text { fluctuerend } \\
\text { stijgend } \\
\text { fluctuerend } \\
\text { fluctuerend } \\
\text { stijgend } \\
\text { constant } \\
\text { stijgend } \\
\text { stijgend } \\
\text { stijgend }\end{array}$ \\
\hline Totaal & 78 & & stijgend \\
\hline
\end{tabular}

Bron: CBS 1995b/ROA 
Tabel 2.2

Percentage bedrijven met automatiseringspersoneel naar bedrijfssector, 1993

\begin{tabular}{|c|c|c|c|}
\hline Bedrijfssector & \multicolumn{2}{|c|}{$\begin{array}{l}\text { Percentage bedrijven met } \\
\text { automatiseringspersoneel '93 } \\
\% \text { typering }\end{array}$} & $\begin{array}{l}\text { Trend } \\
\text { 1991-'93 }\end{array}$ \\
\hline $\begin{array}{l}\text { Delfstoffenwinning, ind. en openb. nutsbedr. } \\
\text { - Voedings- en genotmiddelenindustrie } \\
\text { - Textiel-, kleding- en lederindustrie } \\
\text { - Papier(waren)- en grafische industrie } \\
\text { - Aardolie-, chem., rubber en kunststofverw. ind. } \\
\text { - Metaal- en elektrotechnische industrie } \\
\text { - Overige industrie en delfstoffenwinning } \\
\text { - Openbare nutsbedrijven } \\
\text { Bouwnijverheid en bouwinstallatiebedrijven } \\
\text { - Bouwnijverheid } \\
\text { - Bouwinstallatiebedrijven } \\
\text { Handel } \\
\text { - Groothandel e.d. } \\
\text { - Detailhandel, horeca en reparatiebedrijven } \\
\text { Zakelijke dienstverlening } \\
\text { - Transport-, opslag- en communicatiebedrijven } \\
\text { - Bankwezen } \\
\text { - Verzekeringswezen } \\
\text { - Computerservice- en IT bureaus } \\
\text { - Overige zakelijke dienstverlening } \\
\text { Overige } \\
\text { - Onderwijs } \\
\text { - Gezondheids- en vet. diensten, ms. dienstverl. } \\
\text { - Overige dienstverlening } \\
\text { - Landbouw en visserij }\end{array}$ & $\begin{array}{r}18 \\
7 \\
9 \\
25 \\
36 \\
17 \\
18 \\
88 \\
8 \\
7 \\
11 \\
10 \\
19 \\
5 \\
23 \\
11 \\
26 \\
31 \\
29 \\
23 \\
17 \\
16 \\
28 \\
15 \\
4\end{array}$ & $\begin{array}{l}\text { gemiddeld } \\
\text { laag } \\
\text { laag } \\
\text { gemiddeld } \\
\text { hoog } \\
\text { gemiddeld } \\
\text { gemiddeld } \\
\text { erg hoog } \\
\text { laag } \\
\text { laag } \\
\text { laag } \\
\text { laag } \\
\text { gemiddeld } \\
\text { laag } \\
\text { gemiddeld } \\
\text { laag } \\
\text { gemiddeld } \\
\text { hoog } \\
\text { gemiddeld } \\
\text { gemiddeld } \\
\text { gemiddeld } \\
\text { gemiddeld } \\
\text { gemiddeld } \\
\text { gemiddeld } \\
\text { laag }\end{array}$ & $\begin{array}{l}\text { fluctuerend } \\
\text { sterk dalend } \\
\text { fluctuerend } \\
\text { sterk stijgend } \\
\text { fluctuerend } \\
\text { fluctuerend } \\
\text { fluctuerend } \\
\text { constant } \\
\text { sterk stijgend } \\
\text { fluctuerend } \\
\text { sterk stijgend } \\
\text { fluctuerend } \\
\text { fluctuerend } \\
\text { fluctuerend } \\
\text { dalend } \\
\text { fluctuerend } \\
\text { sterk dalend } \\
\text { fluctuerend } \\
\text { sterk dalend } \\
\text { fluctuerend } \\
\text { sterk stijgend } \\
\text { fluctuerend } \\
\text { sterk stijgend } \\
\text { fluctuerend } \\
\text { fluctuerend }\end{array}$ \\
\hline Totaal & 16 & & fluctuerend \\
\hline
\end{tabular}

Bron: CBS 1995b/ROA 
Tabel 2.3

Automatiseringskosten per werknemer naar bedrijfssector, 1993

\begin{tabular}{|c|c|c|c|}
\hline Bedrijfssector & \multicolumn{2}{|c|}{$\begin{array}{l}\text { Automatiseringskosten } \\
\text { per werknemer '93 } \\
f \quad \text { typering }\end{array}$} & $\begin{array}{l}\text { Trend } \\
\text { 1989-'93 }\end{array}$ \\
\hline $\begin{array}{l}\text { Delfstoffenwinning, ind. en openb. nutsbedr. } \\
\text { - Voedings- en genotmiddelenindustrie } \\
\text { - Textiel-, kleding- en lederindustrie } \\
\text { - Papier(waren)- en grafische industrie } \\
\text { - Aardolie-, chem. rubber en kunststofverw.ind. } \\
\text { - Metaal- en elektrotechnische industrie } \\
\text { - Overige industrie en delfstoffenwinning } \\
\text { - Openbare nutsbedrijven } \\
\text { Bouwnijverheid en bouwinstallatiebedrijven } \\
\text { - Bouwnijverheid } \\
\text { - Bouwinstallatiebedrijven } \\
\text { Handel } \\
\text { - Groothandel e.d. } \\
\text { - Detailhandel, horeca en reparatiebedrijven } \\
\text { Zakelijke dienstverlening } \\
\text { - Transport-, opslag- en communicatiebedr. } \\
\text { - Bankwezen } \\
\text { - Verzekeringswezen } \\
\text { - Computerservice- en IT bureaus } \\
\text { - Overige zakelijke dienstverlening } \\
\text { Overige } \\
\text { - Onderwijs } \\
\text { - Gezondheids- en vet.diensten, ms.dienstverl. } \\
\text { - Overige dienstverlening } \\
\text { - Landbouw en visserij }\end{array}$ & $\begin{array}{l}\text { 4.200,- } \\
3.200,- \\
1.500,- \\
4.000,- \\
8.100,- \\
3.800,- \\
2.000,- \\
7.600,- \\
900,- \\
800,- \\
1.300,- \\
3.100,- \\
5.400,- \\
1.400,- \\
9.500,- \\
4.300,- \\
30.000,- \\
16.600,- \\
53.700,- \\
3.200,- \\
1.500,- \\
1.200,- \\
800,- \\
4.500,- \\
600,-\end{array}$ & $\begin{array}{l}\text { gemiddeld } \\
\text { gemiddeld } \\
\text { gemiddeld } \\
\text { gemiddeld } \\
\text { gemiddeld } \\
\text { gemiddeld } \\
\text { gemiddeld } \\
\text { gemiddeld } \\
\text { laag } \\
\text { laag } \\
\text { gemiddeld } \\
\text { gemiddeld } \\
\text { gemiddeld } \\
\text { gemiddeld } \\
\text { gemiddeld } \\
\text { gemiddeld } \\
\text { erg hoog } \\
\text { hoog } \\
\text { erg hoog } \\
\text { gemiddeld } \\
\text { gemiddeld } \\
\text { gemiddeld } \\
\text { laag } \\
\text { gemiddeld } \\
\text { laag }\end{array}$ & $\begin{array}{l}\text { stijgend } \\
\text { sterk stijgend } \\
\text { dalend } \\
\text { stijgend } \\
\text { stijgend } \\
\text { stijgend } \\
\text { sterk dalend } \\
\text { constant } \\
\text { stijgend } \\
\text { stijgend } \\
\text { fluctuerend } \\
\text { fluctuerend } \\
\text { dalend } \\
\text { stijgend } \\
\text { fluctuerend } \\
\text { stijgend } \\
\text { sterk stijgend } \\
\text { fluctuerend } \\
\text { stijgend } \\
\text { dalend } \\
\text { stijgend } \\
\text { sterk stijgend } \\
\text { sterk stijgend } \\
\text { stijgend } \\
\text { fluctuerend }\end{array}$ \\
\hline Totaal & 4.300,- & & constant \\
\hline
\end{tabular}

Bron: CBS 1995b/ROA 
Tabel 2.4

Gemiddelde R\&D-intensiteit en het aandeel bedrijven zonder R\&D-intensiteit naar bedrijfssector, 1992

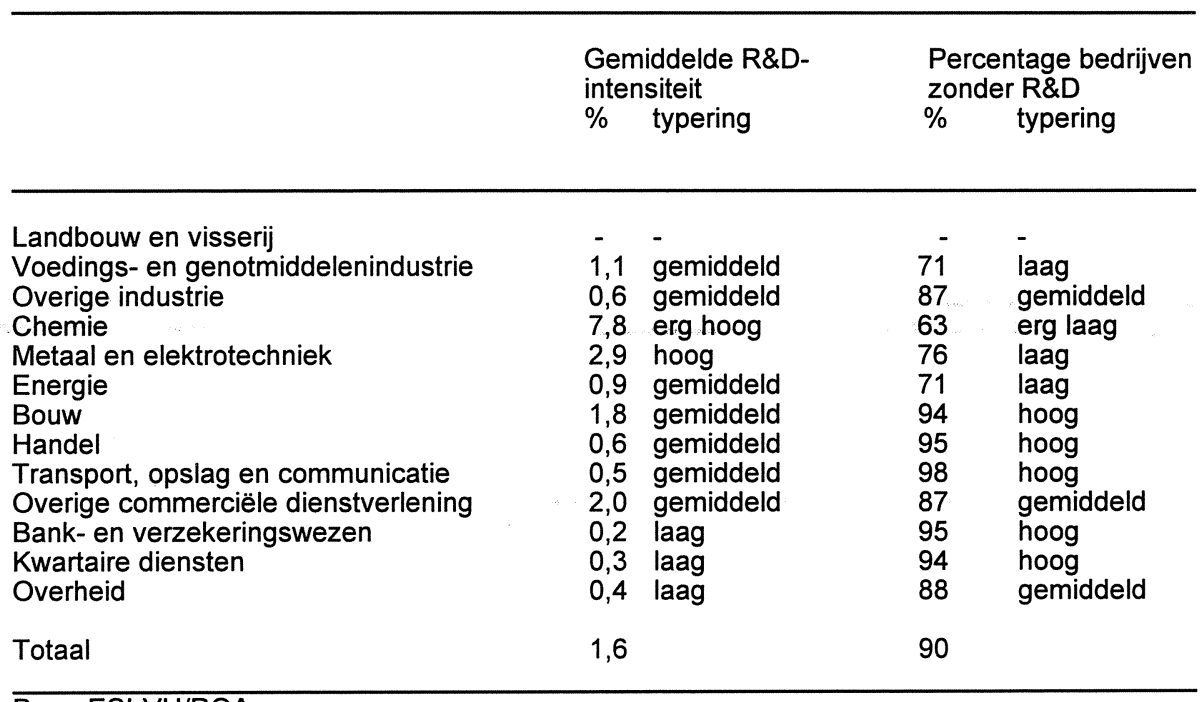

Bron: ESI-VU/ROA

Tabel 2.5

Aandeel bedrijven met nieuwe en/of verbeterde produkten of diensten naar bedrijfssector, 1992

$\begin{array}{ll}\text { Aandeel bedrijven } & \text { Aandeel bedrijven } \\ \text { met nieuwe } & \text { met nieuwe } \\ \text { produkten voor het } & \text { produkten voor de } \\ \text { bedrijf } & \text { bedrijfstak } \\ \% \text { typering } & \% \text { typering }\end{array}$

Landbouw en visserij

Voedings- en genotmiddelenindustrie

Overige industrie

Chemie

Metaal en elektrotechniek

Energie

Bouw

Handel

Transport, opslag en communicatie

Overige commerciële dienstverlening

Bank- en verzekeringswezen

Kwartaire diensten

Overheid

hoog
gemiddeld
erg hoog
gemiddeld
hoog
laag
laag
laag
laag
laag
laag
hoog

gemiddeld

gemiddeld

erg hoog

gemiddeld

erg hoog

laag

laag

laag

gemiddeld

gemiddeld

laag

Totaal

23

hoog

Bron: ESI-VU/ROA 
Tabel 2.6

Aandeel bedrijven die octrooien hebben aangevraagd naar bedrijfssector, 1992

Aandeel bedrijven met octrooien

$\% \quad$ typering

\begin{abstract}
Landbouw en visserij
Voedings- en genotmiddelenindustrie

Overige industrie

Chemie

Metaal en elektrotechniek

Energie

Bouw

Handel

Transport, opslag en communicatie

Overige commerciële dienstverlening

Bank-en verzekeringswezen

Kwartaire diensten
\end{abstract}

Overheid

Totaal gemiddeld

gemiddeld

erg hoog

hoog

gemiddeld

gemiddeld

gemiddeld

laag

gemiddeld

gemiddeld

gemiddeld

laag

Bron: ESI-VU/ROA 
Tabel 2.7

Ontwikkeling aantal werkenden naar bedrijfssector 1990-1994 en uitbreidingsvraag 1995-2000 (gemiddelde procentuele groei per jaar)

\begin{tabular}{|c|c|c|c|}
\hline Bedrijfssector & $\begin{array}{l}\text { werkenden } \\
\text { m. '93/'94) }\end{array}$ & $\begin{array}{r}1990-1994 \\
\%\end{array}$ & $\begin{array}{r}1995-2000 \\
\%\end{array}$ \\
\hline $\begin{array}{l}\text { Landbouw en visserij } \\
\text { Voedings- en genotmiddelenindustrie } \\
\text { Overige industrie } \\
\text { Chemie } \\
\text { Metaal en elektrotechniek } \\
\text { Energie } \\
\text { Bouw } \\
\text { Handel } \\
\text { Transport, opslag en communicatie } \\
\text { Overige commerciële dienstverlening } \\
\text { Bank- en verzekeringswezen } \\
\text { Kwartaire diensten } \\
\text { Overheid }\end{array}$ & $\begin{array}{r}231.500 \\
157.500 \\
242.500 \\
125.000 \\
491.000 \\
65.000 \\
428.500 \\
822.000 \\
373.500 \\
756.500 \\
207.500 \\
937.000 \\
609.500\end{array}$ & $\begin{array}{r}-3,6 \\
-1,7 \\
-2,7 \\
-2,2 \\
-2,8 \\
1,3 \\
-0,3 \\
0,7 \\
1,7 \\
2,9 \\
-1,1 \\
1,4 \\
1,0\end{array}$ & $\begin{array}{r}-2,9 \\
-0,6 \\
-0,3 \\
1,8 \\
0,5 \\
0,4 \\
0,6 \\
1,8 \\
0,7 \\
1,9 \\
-0,6 \\
2,0 \\
-0,9\end{array}$ \\
\hline Totaal & 5.885 .500 & 1,0 & 0,8 \\
\hline
\end{tabular}

Bron: CBS/CPB/ROA 
Tabel 2.8

Opleidingsactiviteiten van bedrijven en instellingen naar bedrijfstak/bedrijfsklasse, 1993

\begin{tabular}{|c|c|c|c|c|}
\hline & \multicolumn{2}{|c|}{$\begin{array}{l}\text { Bedrijven met } \\
\text { opleidingsactiviteiten }\end{array}$} & \multicolumn{2}{|c|}{$\begin{array}{l}\text { Bedrijven met } \\
\text { interne of externe } \\
\text { opleidingen }\end{array}$} \\
\hline & $\%$ & typering & $\%$ & typering \\
\hline $\begin{array}{l}\text { Landbouw en visserij } \\
\text { Delfstoffenwinning } \\
\text { Industrie } \\
\text { - Voedings- en genotmiddelenindustrie } \\
\text { - Textiel- en kledingindustrie } \\
\text { - Papier- en kartonindustrie } \\
\text { - Aardolie-, chemische, glas- en bouwmat. industrie } \\
\text { - Basismetaalindustrie, metaalproduktenindustrie } \\
\text { - Machine en apparatenindustrie } \\
\text { - Auto- en transportmiddelenindustrie } \\
\text { - Rest industrie } \\
\text { Energie- en waterleidingbedrijven } \\
\text { Bouwnijverheid } \\
\text { Handel } \\
\text { - Autohandel en reparatie } \\
\text { - Groothandel } \\
\text { - Detailhandel } \\
\text { Horeca } \\
\text { Vervoer en communicatie } \\
\text { Financiële instellingen } \\
\text { Zak. dienstverl., cultuur en overige dienstverlening }\end{array}$ & $\begin{array}{l}29 \\
47 \\
49 \\
39 \\
40 \\
47 \\
61 \\
51 \\
59 \\
50 \\
40 \\
96 \\
40 \\
45 \\
62 \\
46 \\
36 \\
16 \\
34 \\
73 \\
55\end{array}$ & $\begin{array}{l}\text { laag } \\
\text { gemiddeld } \\
\text { gemiddeld } \\
\text { laag } \\
\text { gemiddeld } \\
\text { gemiddeld } \\
\text { hoog } \\
\text { gemiddeld } \\
\text { hoog } \\
\text { gemiddeld } \\
\text { gemiddeld } \\
\text { erg hoog } \\
\text { gemiddeld } \\
\text { gemiddeld } \\
\text { hoog } \\
\text { gemiddeld } \\
\text { laag } \\
\text { erg laag } \\
\text { laag } \\
\text { erg hoog } \\
\text { gemiddeld }\end{array}$ & $\begin{array}{l}19 \\
37 \\
37 \\
28 \\
22 \\
38 \\
51 \\
38 \\
46 \\
36 \\
30 \\
96 \\
31 \\
34 \\
52 \\
34 \\
27 \\
12 \\
28 \\
64 \\
44\end{array}$ & $\begin{array}{l}\text { laag } \\
\text { gemiddelo } \\
\text { gemiddeld } \\
\text { laag } \\
\text { laag } \\
\text { gemiddelo } \\
\text { laag } \\
\text { gemiddeld } \\
\text { gemiddeld } \\
\text { gemiddeld } \\
\text { gemiddeld } \\
\text { erg hoog } \\
\text { gemiddelo } \\
\text { gemiddelo } \\
\text { hoog } \\
\text { gemiddelo } \\
\text { laag } \\
\text { erg laag } \\
\text { laag } \\
\text { erg hoog } \\
\text { gemiddelc }\end{array}$ \\
\hline Totaal & 45 & & 35 & \\
\hline
\end{tabular}

Bron: CBS 1995a/ROA 
Tabel 2.9

Bedrijven en instellingen met trainingen op de werkplek en overige opleidingsactiviteiten naar bedrijfstak/bedrijfsklasse, 1993

\begin{tabular}{|c|c|c|c|c|}
\hline & \multicolumn{2}{|c|}{$\begin{array}{l}\text { Trainingen } \\
\text { op de werkplek } \\
\% \quad \text { typering }\end{array}$} & \multicolumn{2}{|c|}{$\begin{array}{l}\text { Overige } \\
\text { opleidingsactiviteiten } \\
\qquad \% \quad \text { typering }\end{array}$} \\
\hline $\begin{array}{l}\text { Landbouw en visserij } \\
\text { Delfstoffenwinning } \\
\text { Industrie } \\
\text { - Voedings- en genotmiddelenindustrie } \\
\text { - Metaal- en elektrotechnische industrie } \\
\text { - Overige industrie } \\
\text { Energie- en waterleidingbedrijven } \\
\text { Bouwnijverheid } \\
\text { Handel } \\
\text { - Autohandel en reparatie } \\
\text { - Groothandel } \\
\text { - Detailhandel } \\
\text { Horeca } \\
\text { Vervoer en communicatie } \\
\text { Financiële instellingen } \\
\text { Zak. dienstverl., cultuur en overige dienstverlening }\end{array}$ & $\begin{array}{r}12 \\
15 \\
21 \\
12 \\
22 \\
23 \\
14 \\
11 \\
17 \\
20 \\
17 \\
16 \\
7 \\
9 \\
34 \\
20\end{array}$ & $\begin{array}{l}\text { laag } \\
\text { gemiddeld } \\
\text { hoog } \\
\text { laag } \\
\text { hoog } \\
\text { hoog } \\
\text { gemiddeld } \\
\text { laag } \\
\text { gemiddeld } \\
\text { gemiddeld } \\
\text { gemiddeld } \\
\text { gemiddeld } \\
\text { erg laag } \\
\text { laag } \\
\text { erg hoog } \\
\text { gemiddeld }\end{array}$ & $\begin{array}{l}19 \\
42 \\
40 \\
19 \\
49 \\
40 \\
88 \\
32 \\
40 \\
57 \\
48 \\
22 \\
13 \\
26 \\
69 \\
57\end{array}$ & $\begin{array}{l}\text { laag } \\
\text { gemiddeld } \\
\text { gemiddeld } \\
\text { laag } \\
\text { gemiddeld } \\
\text { gemiddeld } \\
\text { erg hoog } \\
\text { gemiddeld } \\
\text { gemiddeld } \\
\text { hoog } \\
\text { gemiddeld } \\
\text { laag } \\
\text { erg laag } \\
\text { laag } \\
\text { hoog } \\
\text { hoog }\end{array}$ \\
\hline Totaal & 16 & & 39 & \\
\hline
\end{tabular}

Bron: CBS 1995a/ROA 


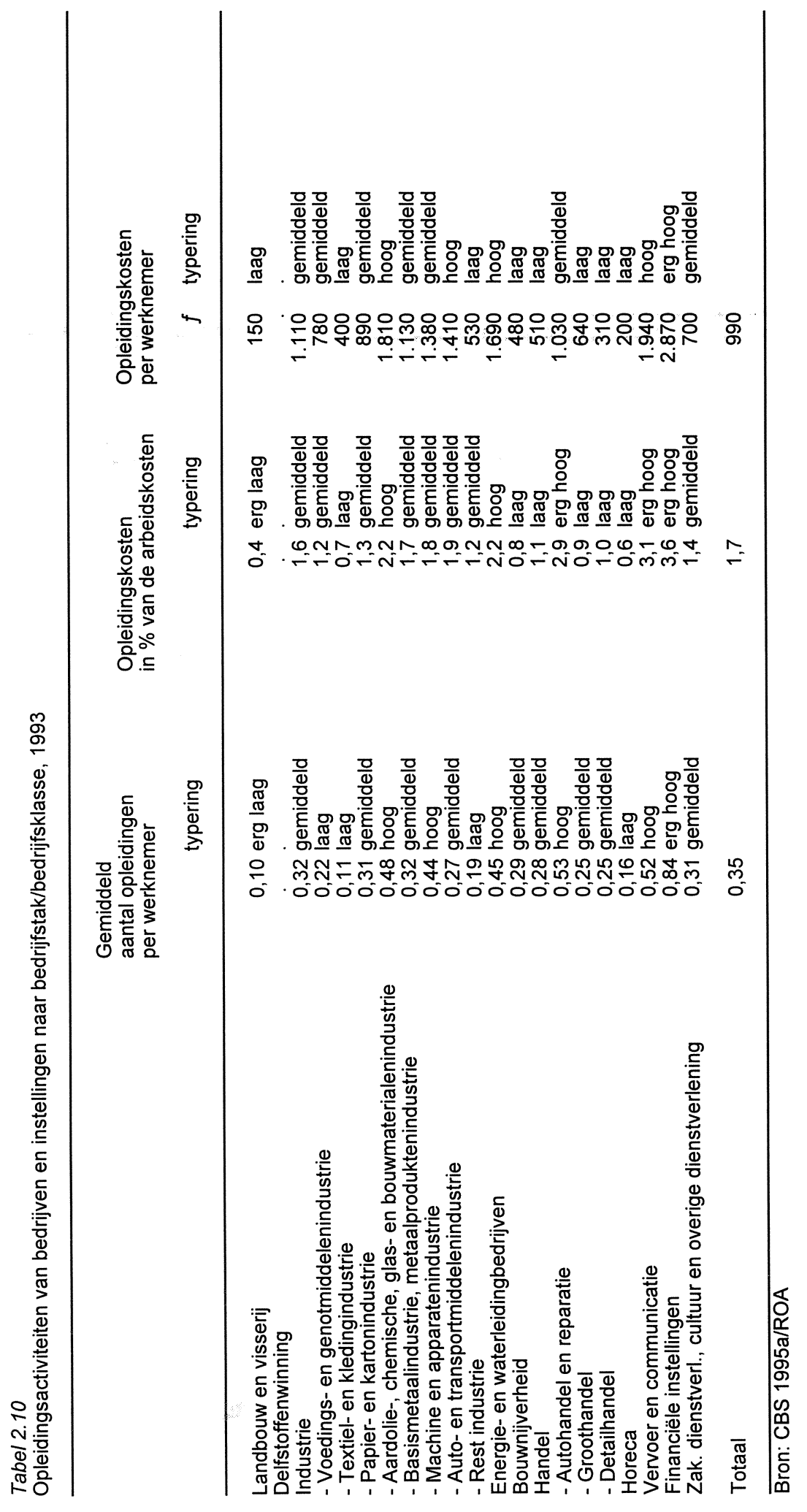




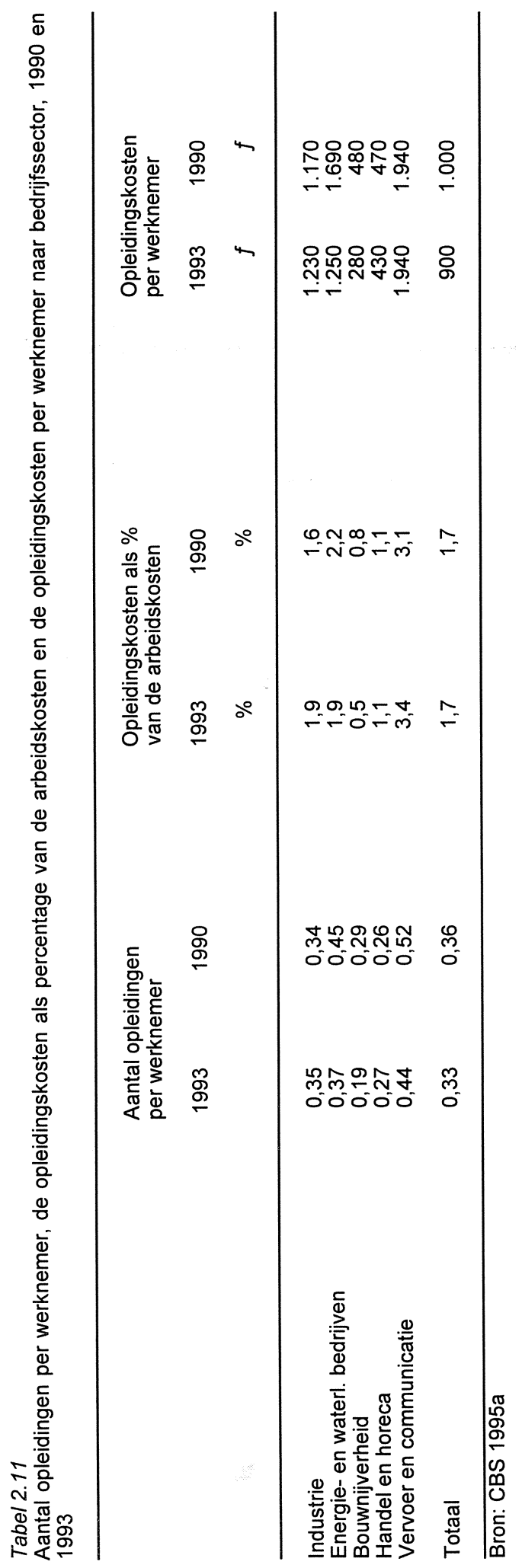


Tabel 2.12

Totale opleidingskosten en kosten per gevolgde opleiding naar bedrijfstak/bedrijfsklasse naar bedrijfssector, 1993

\begin{tabular}{lrllll}
\hline & $\begin{array}{c}\text { Totale opleidings- } \\
\text { kosten }\end{array}$ & \multicolumn{2}{l}{$\begin{array}{l}\text { Kosten per gevolgde } \\
\text { opleiding }\end{array}$} \\
& mln $f$ & typering & $f$ & typering \\
\hline Landbouw en visserij & & & & \\
Delfstoffenwinning & & laag & 1.600 & laag \\
Industrie & 1.031 & erg hoog & 3.430 & hoog \\
- Voedings- en genotmiddelenindustrie & 112 & laag & 3.540 & hoog \\
- Metaal- en elektrotechnische industrie & 450 & hoog & 3.470 & hoog \\
- Overige industrie & 469 & hoog & 3.370 & hoog \\
Energie- en waterleidingbedrijven & 75 & laag & 3.730 & hoog \\
Bouwnijverheid & 151 & gemiddeld & 1.650 & laag \\
Handel & 391 & hoog & 1.830 & laag \\
- Autohandel en reparatie & 82 & laag & 1.950 & laag \\
- Groothandel & 189 & gemiddeld & 2.590 & gemiddeld \\
- Detailhandel & 119 & laag & 1.220 & erg laag \\
Horeca & 22 & laag & 1.210 & erg laag \\
Vervoer en communicatie & 707 & erg hoog & 3.710 & hoog \\
Financiële instellingen & 549 & hoog & 3.390 & hoog \\
Zak. dienstverl., cultuur en overige dienstverlening & 528 & hoog & 2.290 & gemiddeld \\
Total & & & & & \\
& 3.515 & & 2.820 & \\
\hline
\end{tabular}

Bron: CBS 1995a/ROA

Tabel 2.13

Opleidingsactieve bedrijven en instellingen met een opleidingsbeleid voor specifieke groepen ${ }^{1}$ werknemers naar bedrijfssector, 1993

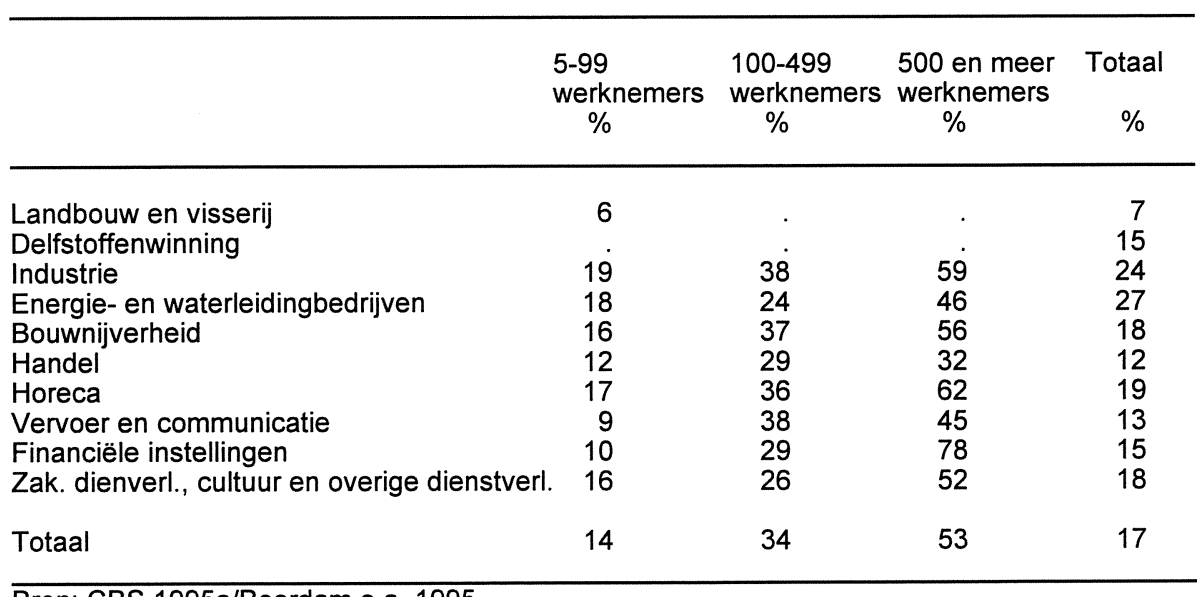

Bron: CBS 1995a/Boerdam e.a. 1995

1. Vrouwen, on- of laaggeschoolden, gehandicapten, jongeren, ouderen, allochtonen en overbodige werknemers. 
Tabel 2.14

Opleidingsactieve bedrijven en instellingen met een opleidingsbeleid voor ouderen naar bedrijfssector, 1993

\begin{tabular}{lcccc}
\hline & $\begin{array}{l}5-99 \\
\text { werk- } \\
\text { nemers } \\
\%\end{array}$ & $\begin{array}{l}100-499 \\
\text { werk- } \\
\text { nemers } \\
\%\end{array}$ & $\begin{array}{l}500 \text { en } \\
\text { meer werk- } \\
\text { nemers } \\
\%\end{array}$ & Totaal \\
\hline Landbouw en visserij & 1 & & & 2 \\
Delfstoffenwinning & 3 & 4 & 17 & - \\
Industrie & - & 4 & 5 & 3 \\
Energie-en waterleidingbedrijven & 3 & 5 & 16 & 3 \\
Bouwnijverheid & 2 & 2 & 5 & 2 \\
Handel & 1 & - & - & 1 \\
Horeca & 2 & 3 & 6 & 2 \\
Vervoer en communicatie & 4 & - & 7 & 3 \\
Financiële instellingen & 3 & 4 & 9 & 3 \\
Zak. dienverl., cultuur en overige dienstverl. & 3 & 4 & 11 & 3 \\
Totaal & 2 & & & \\
\hline
\end{tabular}

Bron: CBS 1995a / Boerdam e.a. 1995

Tabel 2.15

Opleidingsactieve bedrijven en instellingen met een opleidingsbeleid voor ongeschoolde of laaggeschoolde werknemers naar bedrijfssector, 1993

\begin{tabular}{lcccc}
\hline & $\begin{array}{c}5-99 \\
\text { werknem. } \\
\%\end{array}$ & $\begin{array}{c}\begin{array}{c}100-499 \\
\text { werknem. } \\
\%\end{array} \\
\text { Landbouw en visserij }\end{array}$ & $\begin{array}{c}500 \text { en meer } \\
\text { werknem. } \\
\%\end{array}$ & $\begin{array}{c}\text { Totaal } \\
\%\end{array}$ \\
\hline $\begin{array}{l}\text { Delfstoffenwinning } \\
\text { Industrie }\end{array}$ & 2 &. &. & 2 \\
Energie- en waterleidingbedrijven & 7 & 19 & 26 & 3 \\
Bouwnijverheid & 18 & 12 & 23 & 16 \\
Handel & 5 & 17 & 13 & 6 \\
Horeca & 4 & 10 & 11 & 4 \\
Vervoer en communicatie & 4 & 6 & 39 & 5 \\
Financiële instellingen & 3 & 9 & - & 3 \\
Zak. dienverl., cultuur en overige dienstverl. & 1 & 3 & 44 & 3 \\
Totaal & 3 & 5 & 12 & 4 \\
\hline
\end{tabular}

Bron: CBS 1995a / Boerdam e.a. 1995 
INFORMATIE OVER BEROEPEN 

Tabel 3.1

Informatietechnologie naar beroepssegment, 1993-1994

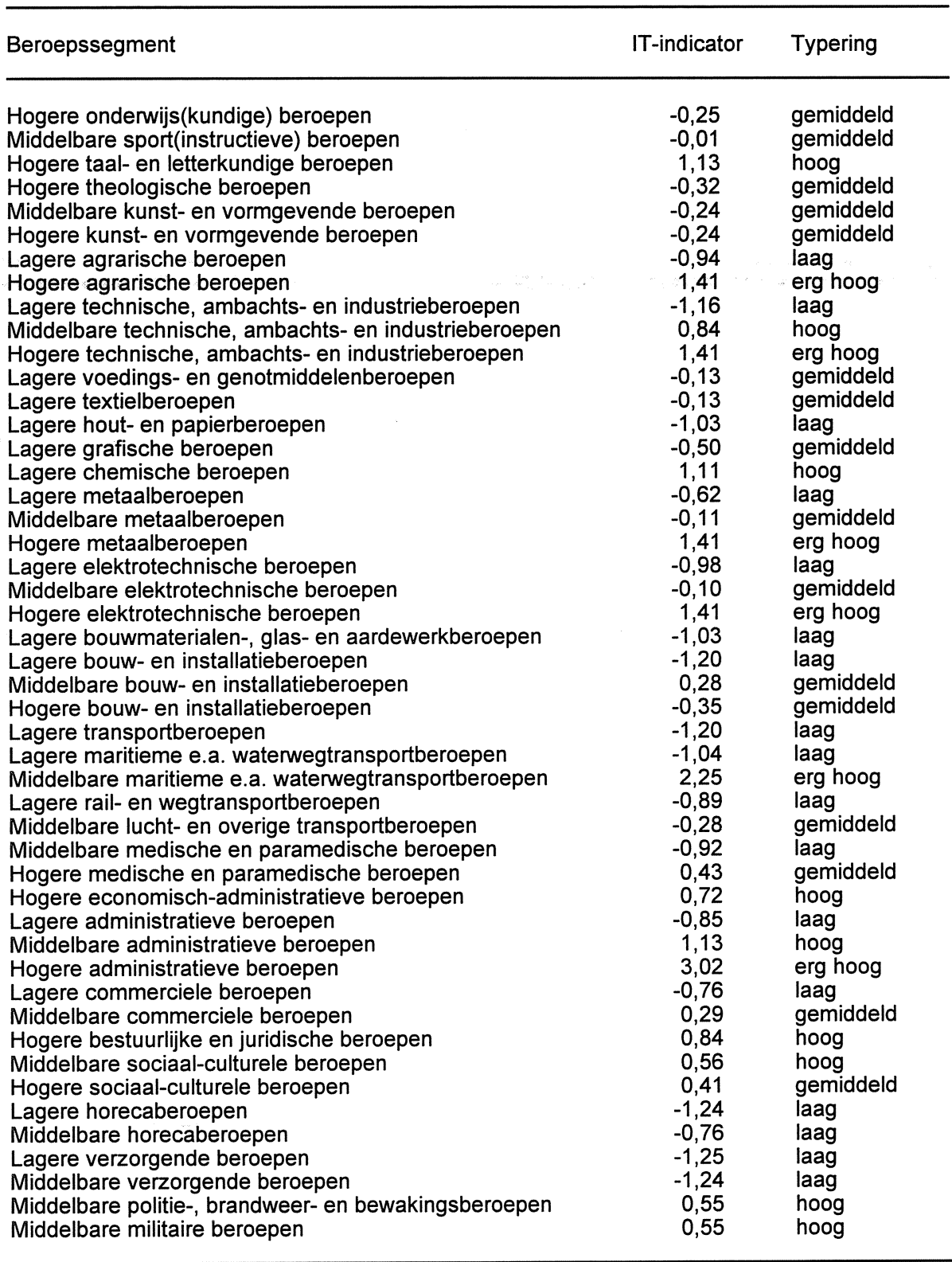

Bron: De Graaf e.a./CBS/ROA 
Tabel 3.2

Verwachte netto baancreatie naar beroepssegment, 1995-2000

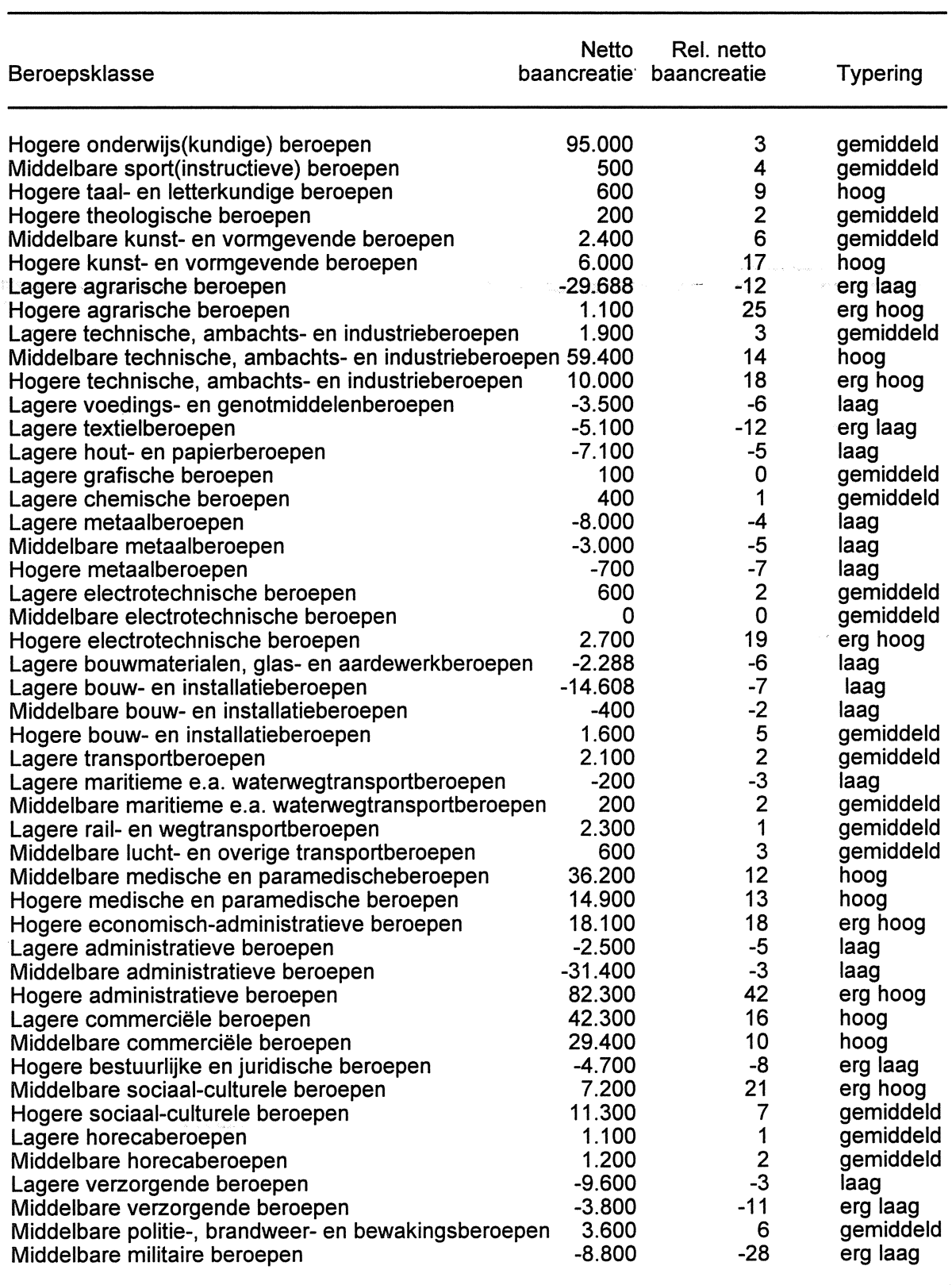

Bron: CBSIROA 
Tabel 3.3

Verwachte reallocatie naar beroepssegment, 1995-2000

\begin{tabular}{|c|c|c|c|}
\hline Beroepsklasse & \multicolumn{2}{|c|}{$\begin{array}{l}\text { Reallocatie } \\
\text { abs. } \%\end{array}$} & Typering \\
\hline $\begin{array}{l}\text { Hogere onderwijs(kundige) beroepen } \\
\text { Middelbare sport(instructieve) beroepen } \\
\text { Hogere taal- en letterkundige beroepen } \\
\text { Hogere theologische beroepen } \\
\text { Middelbare kunst- en vormgevende beroepen } \\
\text { Hogere kunst- en vormgevende beroepen } \\
\text { Lagere agrarische beroepen } \\
\text { Hogere agrarische beroepen } \\
\text { Lagere technische, ambachts- en industrieberoepen } \\
\text { Middelbare technische, ambachts- en industrieberoepen } \\
\text { Hogere technische, ambachts- en industrieberoepen } \\
\text { Lagere voedings- en genotmiddelenberoepen } \\
\text { Lagere textielberoepen } \\
\text { Lagere hout- en papierberoepen } \\
\text { Lagere grafische beroepen } \\
\text { Lagere chemische beroepen } \\
\text { Lagere metaalberoepen } \\
\text { Middelbare metaalberoepen } \\
\text { Hogere metaalberoepen } \\
\text { Lagere electrotechnische beroepen } \\
\text { Middelbare electrotechnische beroepen } \\
\text { Hogere electrotechnische beroepen } \\
\text { Lagere bouwmaterialen-. glas- en aardewerkberoepen } \\
\text { Lagere bouw- en installatieberoepen } \\
\text { Middelbare bouw-en installatieberoepen } \\
\text { Hogere bouw- en installatieberoepen } \\
\text { Lagere transportberoepen } \\
\text { Lagere maritieme e.a. waterwegtransportberoepen } \\
\text { Middelbare maritieme e.a. waterwegtransportberoepen } \\
\text { Lagere rail- en wegtransportberoepen } \\
\text { Middelbare lucht- en overige transportberoepen } \\
\text { Middelbare medische en paramedische beroepen } \\
\text { Hogere medische en paramedische beroepen } \\
\text { Hogere economische-administratieve beroepen } \\
\text { Lagere administratieve beroepen } \\
\text { Middelbare administratieve beroepen } \\
\text { Hogere administratieve beroepen } \\
\text { Lagere commerciële beroepen } \\
\text { Middelbare commerciële beroepen } \\
\text { Hogere bestuurlijke en juridische beroepen } \\
\text { Middelbare sociaal-culturele beroepen } \\
\text { Hogere sociaal-culturele beroepen } \\
\text { Lagere horecaberoepen } \\
\text { Middelbare horecaberoepen } \\
\text { Lagere verzorgende beroepen } \\
\text { Middelbare verzorgende beroepen } \\
\text { Middelbare politie-, brandweer- en bewakingsberoepen } \\
\text { Middelbare militaire beroepen }\end{array}$ & $\begin{array}{r}0 \\
0 \\
300 \\
0 \\
0 \\
0 \\
1.300 \\
0 \\
2.200 \\
2.200 \\
1.500 \\
1.400 \\
1.310 \\
4.100 \\
700 \\
1.000 \\
10.400 \\
1.500 \\
200 \\
2.200 \\
3.400 \\
0 \\
1.500 \\
1.200 \\
1.800 \\
0 \\
8.900 \\
500 \\
300 \\
1.500 \\
0 \\
100 \\
500 \\
400 \\
2.300 \\
40.600 \\
700 \\
0 \\
8.000 \\
4.400 \\
300 \\
4.500 \\
1.400 \\
1.700 \\
2.700 \\
200 \\
0 \\
0\end{array}$ & $\begin{array}{l}0 \\
0 \\
4 \\
0 \\
0 \\
0 \\
1 \\
0 \\
4 \\
1 \\
3 \\
2 \\
3 \\
3 \\
2 \\
4 \\
5 \\
3 \\
2 \\
7 \\
3 \\
0 \\
4 \\
1 \\
7 \\
0 \\
7 \\
6 \\
3 \\
1 \\
0 \\
0 \\
0 \\
0 \\
5 \\
4 \\
0 \\
0 \\
3 \\
7 \\
1 \\
3 \\
1 \\
3 \\
1 \\
1 \\
0 \\
0\end{array}$ & $\begin{array}{l}\text { erg laag } \\
\text { erg laag } \\
\text { gemiddeld } \\
\text { erg laag } \\
\text { erg laag } \\
\text { erg laag } \\
\text { laag } \\
\text { erg laag } \\
\text { gemiddeld } \\
\text { laag } \\
\text { gemiddeld } \\
\text { laag } \\
\text { gemiddeld } \\
\text { gemiddeld } \\
\text { laag } \\
\text { gemiddeld } \\
\text { hoog } \\
\text { gemiddeld } \\
\text { laag } \\
\text { erg hoog } \\
\text { gemiddeld } \\
\text { erg laag } \\
\text { gemiddeld } \\
\text { laag } \\
\text { erg hoog } \\
\text { erg laag } \\
\text { erg hoog } \\
\text { hoog } \\
\text { gemiddeld } \\
\text { laag } \\
\text { erg laag } \\
\text { erg laag } \\
\text { erg laag } \\
\text { erg laag } \\
\text { hoog } \\
\text { gemiddeld } \\
\text { erg laag } \\
\text { erg laag } \\
\text { gemiddeld } \\
\text { erg hoog } \\
\text { laag } \\
\text { gemiddeld } \\
\text { laag } \\
\text { gemiddeld } \\
\text { laag } \\
\text { laag } \\
\text { erg laag } \\
\text { erg laag }\end{array}$ \\
\hline
\end{tabular}

Bron: CBS/ROA 
Tabel 3.4

Verwachte krimp-kengetallen voor beroepssegmenten naar bedrijfssector, 1995-2000

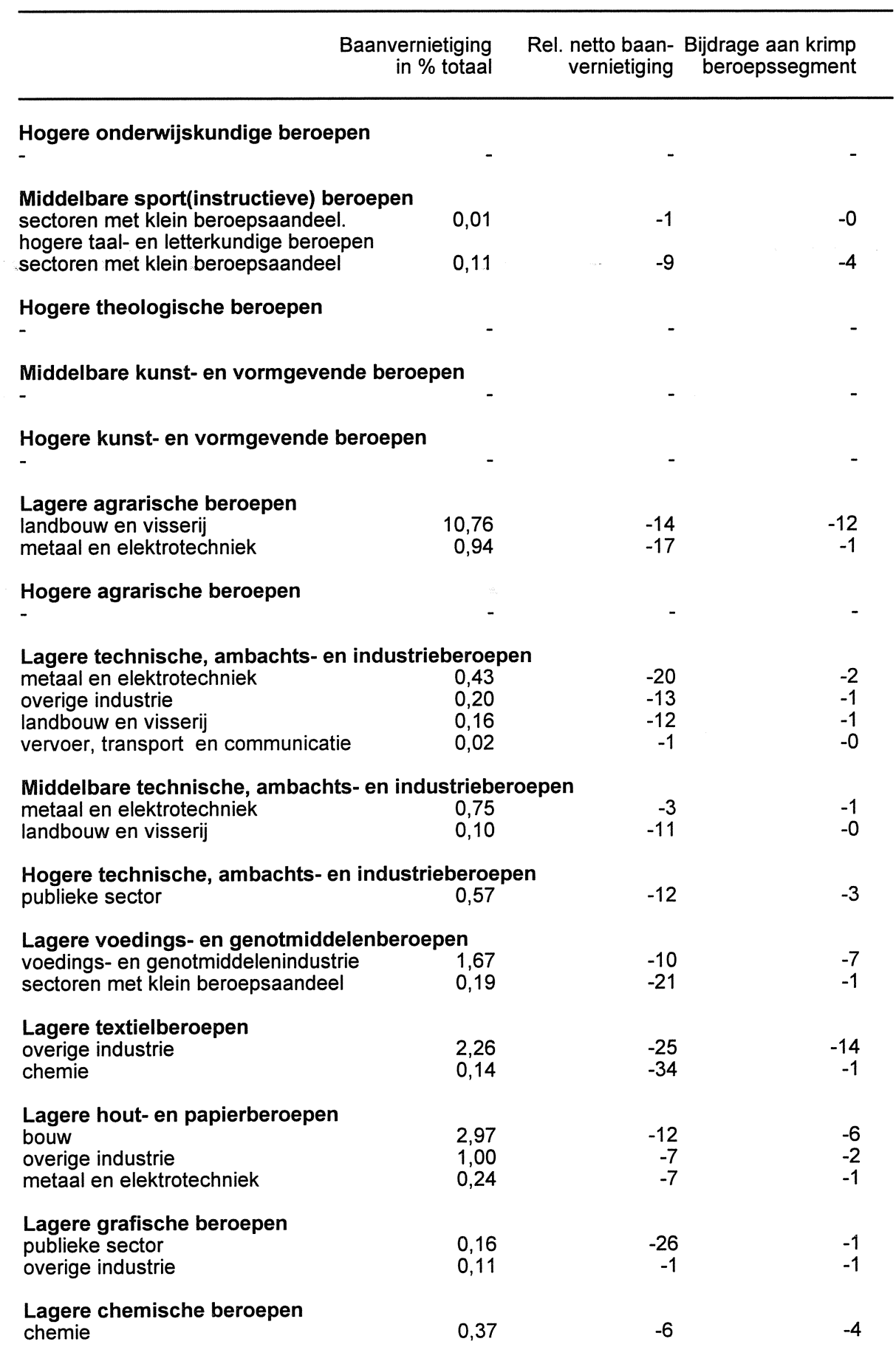


Tabel 3.4 (vervolg)

Verwachte krimp-kengetallen voor beroepssegmenten naar bedrijfssector, 1995-2000

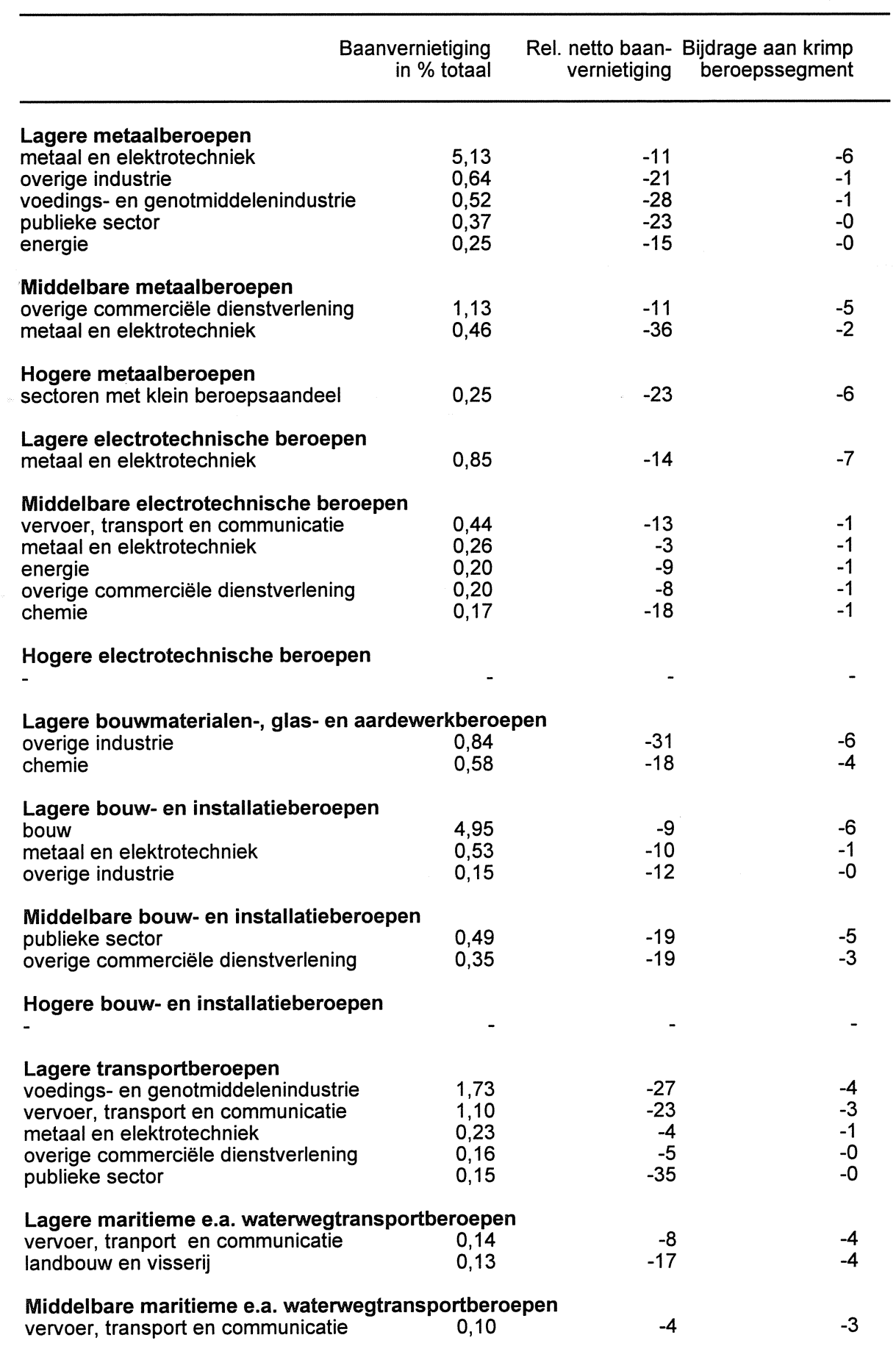


Tabel 3.4 (vervolg)

Verwachte krimp-kengetallen voor beroepssegmenten naar bedrijfssector, 1995-2000

Baanvernietiging

in $\%$ totaal
Rel. netto baan- Bijdrage aan krimp vernietiging beroepssegment

Lagere rail- en wegtransportberoepen

vervoer, transport en communicatie

0,34

voedings- en genotmiddelenindustrie

0,16

metaal en elektrotechniek

0,08

-1
-7
-7

$-7$

Middelbare lucht- en overige transportberoepen

Middelbare medische en paramedische beroepen sectoren met klein beroepsaandeel $\quad 0,03$

Hogere medische en paramedische beroepen publieke sector

Hogere economisch-administratieve beroepen chemie

Lagere administratieve beroepen publieke sector

vervoer, transport en communicatie

overige commerciële dienstverlening

bank- en verzekeringswezen

Middelbare administratieve beroepen publieke sector

bank- en verzekeringswezen

overige industrie

metaal en elektrotechniek

energie

Hogere administratieve beroepen voedings- en genotmiddelenindustrie

Lagere commerciële beroepen

Middelbare commerciële beroepen

bank- en verzekeringswezen

voedings- en genotmiddelenindustrie

overige industrie

metaal en elektrotechniek

Hogere bestuurlijke en juridische beroepen publieke sector

Middelbare sociaal-culturele beroepen publieke sector

Hogere sociaal-culturele beroepen publieke sector 
Tabel 3.4 (vervolg)

Verwachte krimp-kengetallen voor beroepssegmenten naar bedrijfssector, 1995-2000

Baanvernietiging in \% totaal

Rel. netto baan- Bijdrage aan krimp vernietiging beroepssegment

\section{Lagere horecaberoepen}

publieke sector

overige commerciële dienstverlening

sectoren met klein beroepsaandeel

Middelbare horecaberoepen

overige commerciële dienstverlening

0,66

Lagere verzorgende beroepen

overige commerciële dienstverlening

publieke sector

sectoren met klein beroepsaandeel

vervoer, transport en communicatie

overige industrie

0,26

0,24

0,04

3,09

1,35

0,08

0,08

0,05

Middelbare verzorgende beroepen

overige commerciële dienstverlening
$-11$

$-1$

$-1$

$-0$

$-3$
Middelbare politie-, brandweer- en bewakingsberoepen

Middelbare militaire beroepen

publieke sector

3,32

28

-3
-1
-0
-0
-0

$-11$

$-12$

Bron: ROA 


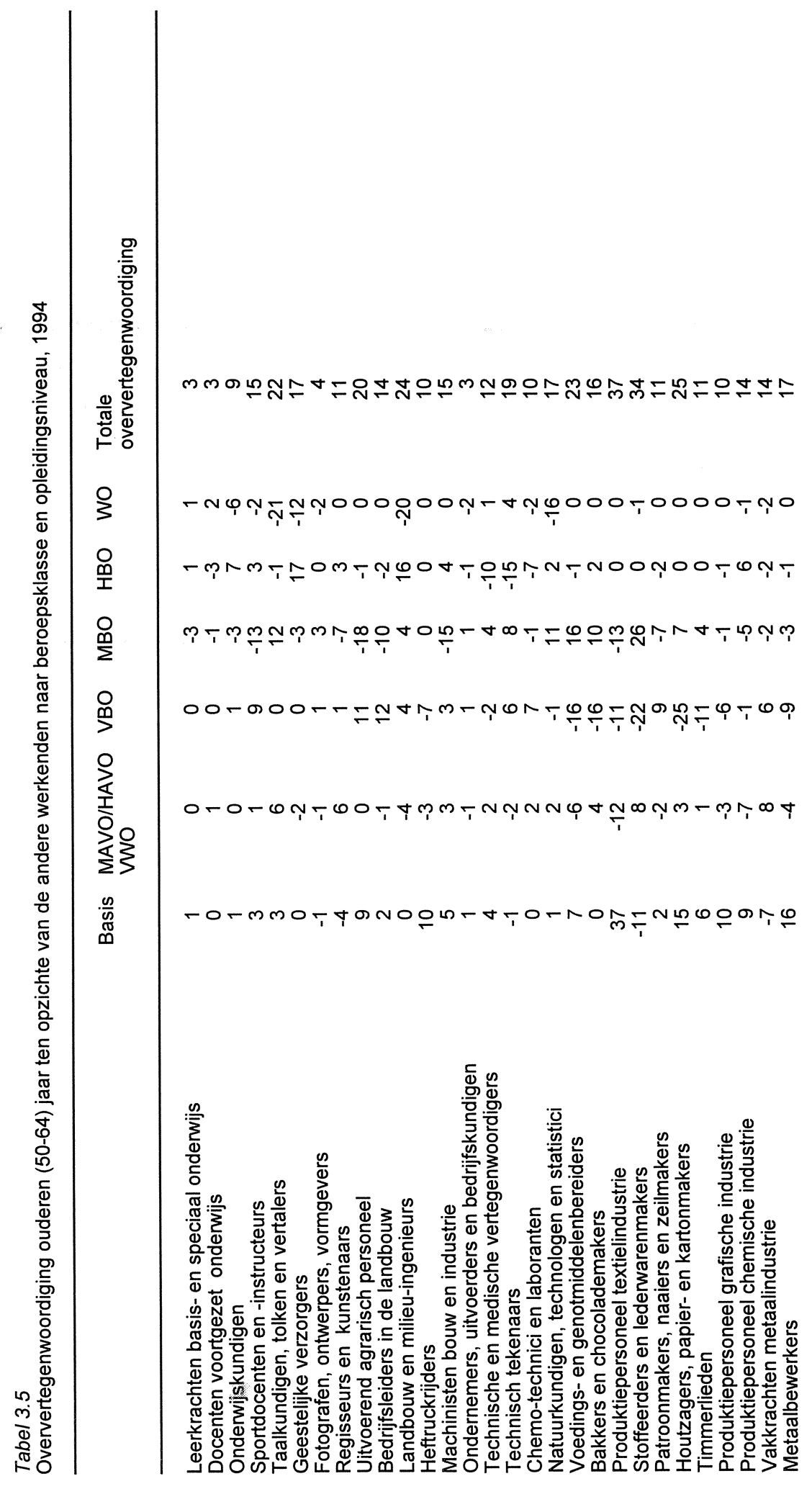




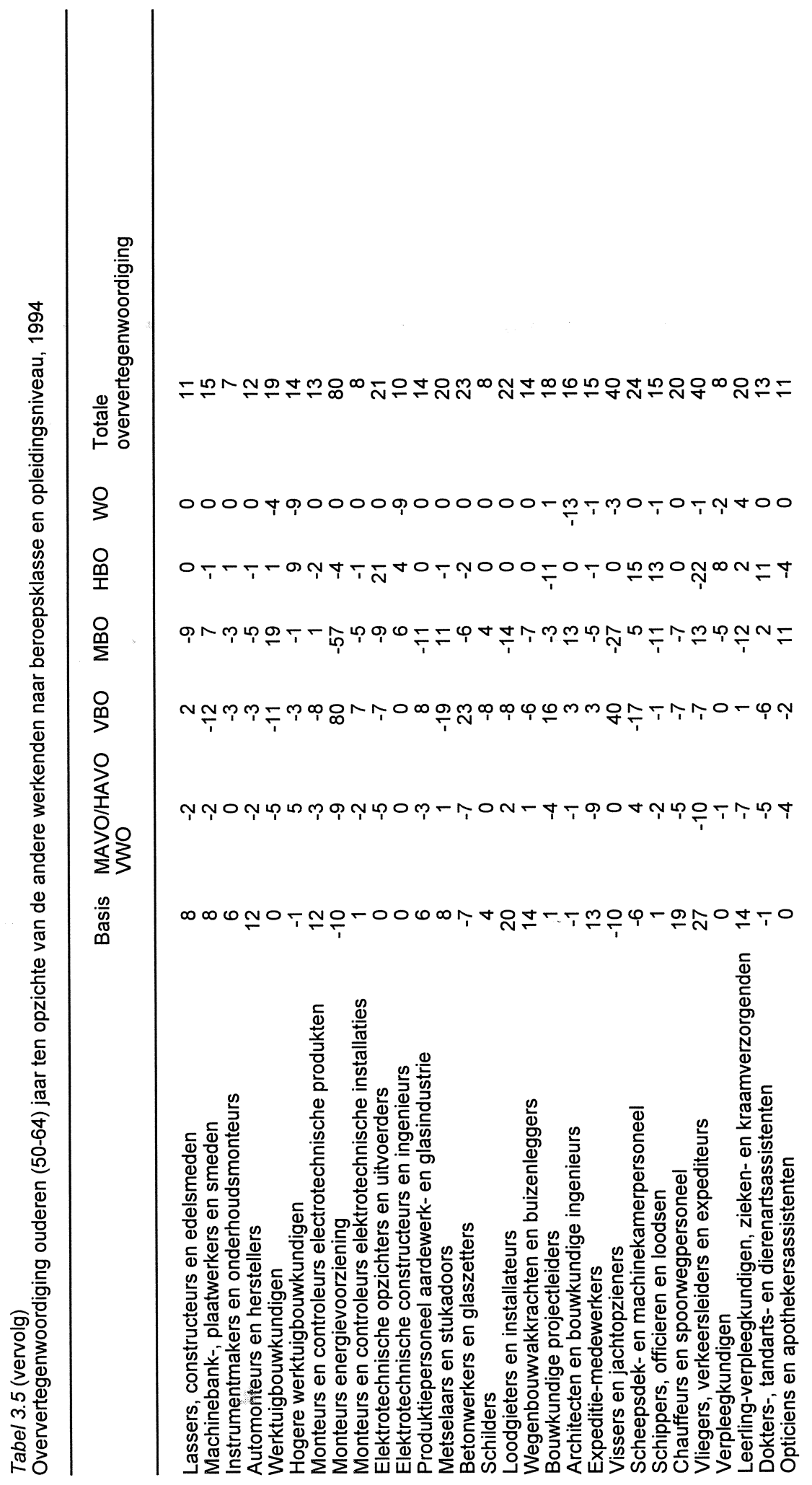




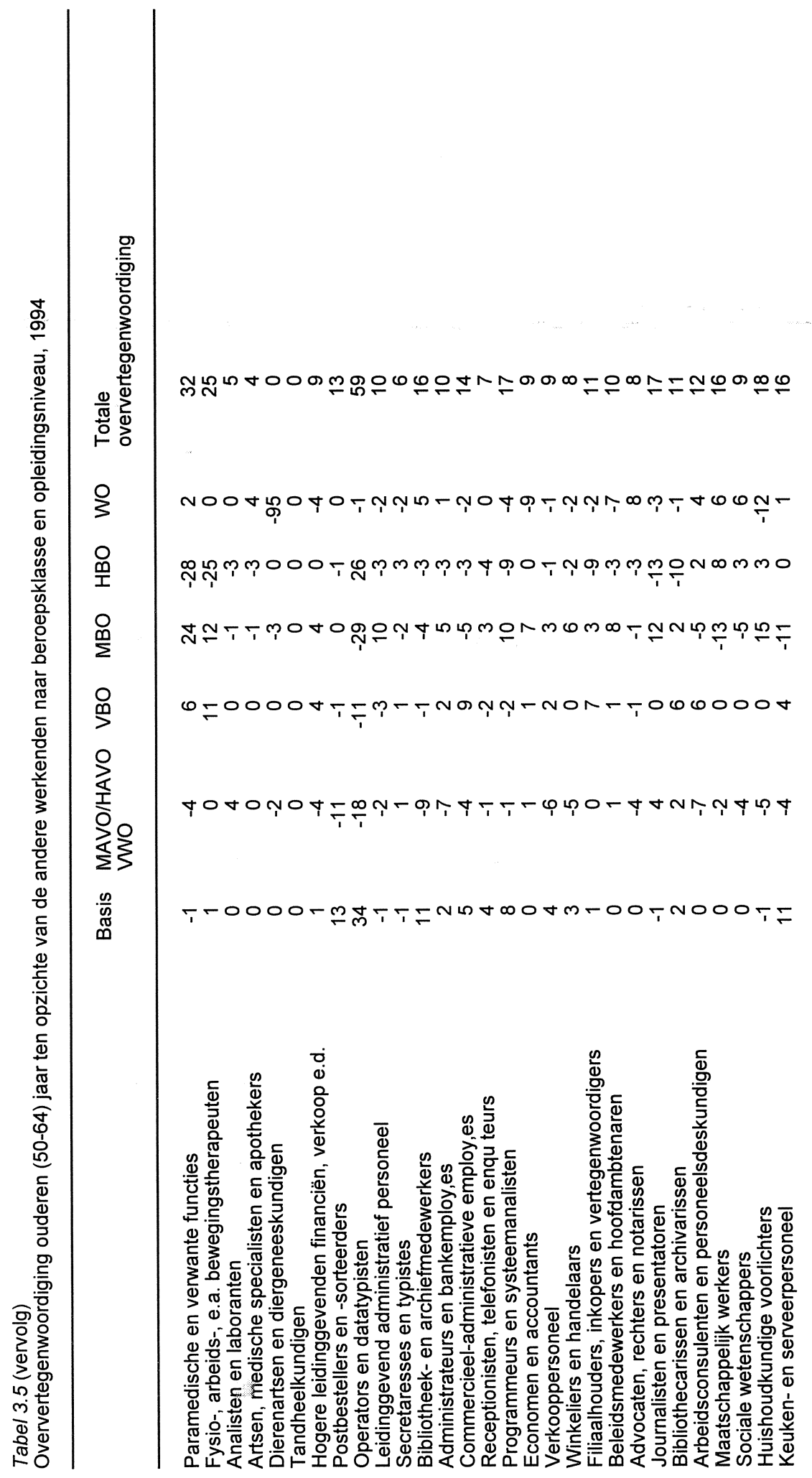




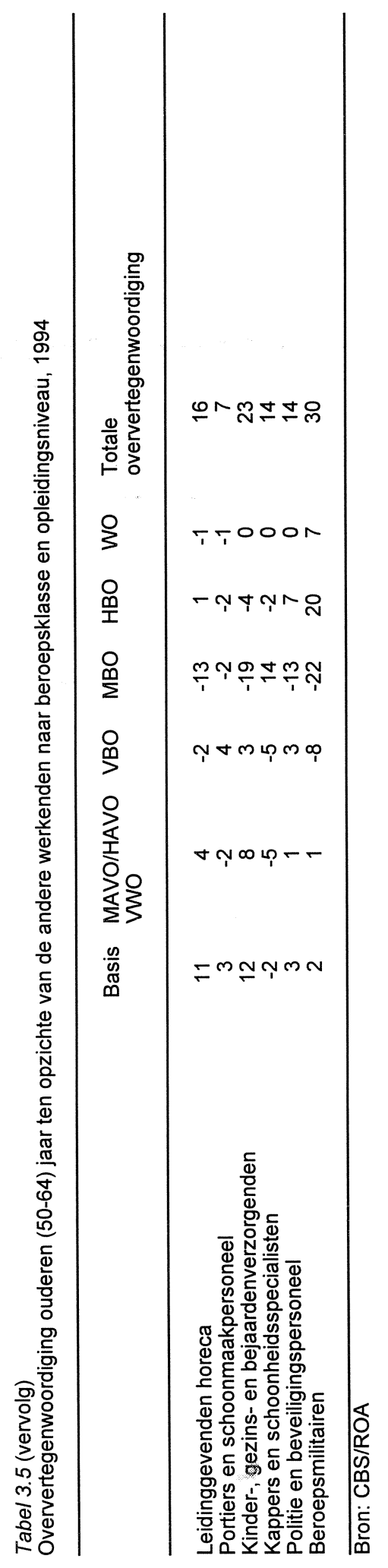


Tabel 3.6

Percentage werkenden dat tussen 1992-1994 een cursus heeft gevolgd naar beroepssegment

\begin{tabular}{|c|c|c|}
\hline Beroepssegment & $\ln \%$ & Typering \\
\hline Hogere onderwijs(kundige) beroepen & 28 & gemiddeld \\
\hline Middelbare sport(instructieve) beroepen & 64 & erg hoog \\
\hline Hogere taal- en letterkundige beroepen & - & - \\
\hline Hogere theologische beroepen & - & - \\
\hline Middelbare kunst- en vormgevende beroepen & - & - \\
\hline Hogere kunst- en vormgevende beroepen & - & - \\
\hline Lagere agrarische beroepen & 20 & laag \\
\hline Hogere agrarische beroepen & - & - \\
\hline Lagere technische, ambachts- en industrieberoepen & 41 & hoog \\
\hline Middelbare technische, ambachts- en industrieberoepen & 37 & hoog \\
\hline Hogere technische, ambachts- en industrieberoepen & - & gemiddeld \\
\hline Lagere voedings- en genotmiddelenberoepen & 17 & laag \\
\hline Lagere textielberoepen & - & erg laag \\
\hline Lagere hout- en papierberoepen & 25 & gemiddeld \\
\hline Lagere grafische beroepen & - & gemiddeld \\
\hline Lagere chemische beroepen & - & gemiddeld \\
\hline Lagere metaalberoepen & 34 & gemiddeld \\
\hline Middelbare metaalberoepen & 23 & gemiddeld \\
\hline Hogere metaalberoepen & - & - \\
\hline Lagere elektrotechnische beroepen & - & erg laag \\
\hline Middelbare elektrotechnische beroepen & 37 & hoog \\
\hline Hogere elektrotechnische beroepen & - & - \\
\hline Lagere bouwmaterialen-, glas- en aardewerkberoepen & - & gemiddeld \\
\hline Lagere bouw- en installatieberoepen & 16 & laag \\
\hline Middelbare bouw- en installatieberoepen & - & gemiddeld \\
\hline Hogere bouw- en installatieberoepen & - & laag \\
\hline Lagere transportberoepen & 20 & laag \\
\hline Lagere maritieme e.a. waterwegtransportberoepen & - & - \\
\hline Middelbare maritieme e.a. waterwegtransportberoepen & - & - \\
\hline Lagere rail- en wegtransportberoepen & 20 & laag \\
\hline Middelbare lucht- en overige transportberoepen & - & laag \\
\hline Middelbare medische en paramedische beroepen & 25 & gemiddeld \\
\hline Hogere medische en paramedische beroepen & 27 & gemiddeld \\
\hline Hogere economisch-administratieve beroepen & 24 & gemiddeld \\
\hline Lagere administratieve beroepen & 20 & laag \\
\hline Middelbare administratieve beroepen & 35 & hoog \\
\hline Hogere administratieve beroepen & 45 & erg hoog \\
\hline Lagere commerciele beroepen & 26 & gemiddeld \\
\hline Middelbare commerciele beroepen & 33 & gemiddeld \\
\hline Hogere bestuurlijke en juridische beroepen & 27 & gemiddeld \\
\hline Middelbare sociaal-culturele beroepen & - & hoog \\
\hline Hogere sociaal-culturele beroepen & 41 & hoog \\
\hline Lagere horecaberoepen & 17 & laag \\
\hline Middelbare horecaberoepen & - & erg hoog \\
\hline Lagere verzorgende beroepen & 18 & laag \\
\hline Middelbare verzorgende beroepen & - & hoog \\
\hline Middelbare politie-, brandweer- en bewakingsberoepen & 43 & hoog \\
\hline Middelbare militaire beroepen & - & gemiddeld \\
\hline
\end{tabular}

Bron: CBS/ROA 
Tabel 3.7

Extra bijscholingsbehoefte (gezien de informatiseringsgraad) en extra omscholingsbehoefte (gezien de verwachte werkgelegenheidskrimp en sectorale reallocatie) naar beroepssegment

\begin{tabular}{|c|c|c|}
\hline Beroepssegment & $\begin{array}{l}\text { Extra } \\
\text { bijscholings- } \\
\text { behoefte }\end{array}$ & $\begin{array}{l}\text { Extra } \\
\text { omscholings- } \\
\text { behoefte }\end{array}$ \\
\hline $\begin{array}{l}\text { Hogere onderwijs(kundige) beroepen } \\
\text { Middelbare sport(instructieve) beroepen } \\
\text { Hogere taal- en letterkundige beroepen } \\
\text { Hogere theologische beroepen } \\
\text { Middelbare kunst- en vormgevende beroepen } \\
\text { Hogere kunst- en vormgevende beroepen } \\
\text { Lagere agrarische beroepen } \\
\text { Hogere agrarische beroepen } \\
\text { Lagere technische, ambachts- en industrieberoepen } \\
\text { Middelbare technische, ambachts- en industrieberoepen } \\
\text { Hogere technische, ambachts- en industrieberoepen } \\
\text { Lagere voedings- en genotmiddelenberoepen } \\
\text { Lagere textielberoepen } \\
\text { Lagere hout- en papierberoepen } \\
\text { Lagere grafische beroepen } \\
\text { Lagere chemische beroepen } \\
\text { Lagere metaalberoepen } \\
\text { Middelbare metaalberoepen } \\
\text { Hogere metaalberoepen } \\
\text { Lagere elektrotechnische beroepen } \\
\text { Middelbare elektrotechnische beroepen } \\
\text { Hogere elektrotechnische beroepen } \\
\text { Lagere bouwmaterialen-, glas- en aardewerkberoepen } \\
\text { Lagere bouw- en installatieberoepen } \\
\text { Middelbare bouw- en installatieberoepen } \\
\text { Hogere bouw- en installatieberoepen } \\
\text { Lagere transportberoepen } \\
\text { Lagere maritieme e.a. waterwegtransportberoepen } \\
\text { Middelbare maritieme e.a. waterwegtransportberoepen } \\
\text { Lagere rail- en wegtransportberoepen } \\
\text { Middelbare lucht- en overige transportberoepen } \\
\text { Middelbare medische en paramedische beroepen } \\
\text { Hogere medische en paramedische beroepen } \\
\text { Hogere economisch-administratieve beroepen } \\
\text { Lagere administratieve beroepen } \\
\text { Middelbare administratieve beroepen } \\
\text { Hogere administratieve beroepen } \\
\text { Lagere commerciele beroepen } \\
\text { Middelbare commerciele beroepen } \\
\text { Hogere bestuurlijke en juridische beroepen } \\
\text { Middelbare sociaal-culturele beroepen } \\
\text { Hogere sociaal-culturele beroepen } \\
\text { Lagere horecaberoepen } \\
\text { Middelbare horecaberoepen } \\
\text { Magere verzorgende beroepen } \\
\text { Midditaire beroepen }\end{array}$ & $\begin{array}{l}\text { gemiddeld } \\
\text { erg klein } \\
\text { - } \\
\text { - } \\
\text { - } \\
\text { - } \\
\text { gemiddeld } \\
\text { - } \\
\text { erg klein } \\
\text { gemiddeld } \\
\text { erg groot } \\
\text { groot } \\
\text { erg groot } \\
\text { klein } \\
\text { gemiddeld } \\
\text { groot } \\
\text { klein } \\
\text { gemiddeld } \\
\text { - } \\
\text { erg groot } \\
\text { klein } \\
\text { - } \\
\text { gemiddeld } \\
\text { gemiddeld } \\
\text { gemiddeld } \\
\text { groot } \\
\text { gemiddeld } \\
\text { - } \\
\text { - } \\
\text { gemiddeld } \\
\text { gemiddeld } \\
\text { gemiddeld } \\
\text { groot } \\
\text { groot } \\
\text { gemiddeld } \\
\text { groot } \\
\text { erg groot } \\
\text { gemiddeld } \\
\text { gemiddeld } \\
\text { groot } \\
\text { gemiddeld } \\
\text { gemiddeld } \\
\text { gemiddeld } \\
\text { erg klein } \\
\text { gemiddeld } \\
\text { erg klein } \\
\text { gemiddeld } \\
\text { gemiddeld }\end{array}$ & $\begin{array}{l}\text { klein } \\
\text { erg klein } \\
\text { gemiddeld } \\
\text { klein } \\
\text { klein } \\
\text { klein } \\
\text { erg groot } \\
\text { klein } \\
\text { klein } \\
\text { klein } \\
\text { gemiddeld } \\
\text { groot } \\
\text { erg groot } \\
\text { groot } \\
\text { gemiddeld } \\
\text { gemiddeld } \\
\text { gemiddeld } \\
\text { groot } \\
\text { gemiddeld } \\
\text { erg groot } \\
\text { klein } \\
\text { klein } \\
\text { groot } \\
\text { groot } \\
\text { gemiddeld } \\
\text { gemiddeld } \\
\text { groot } \\
\text { gemiddeld } \\
\text { gemiddeld } \\
\text { gemiddeld } \\
\text { gemiddeld } \\
\text { gemiddeld } \\
\text { gemiddeld } \\
\text { gemiddeld } \\
\text { groot } \\
\text { gemiddeld } \\
\text { erg klein } \\
\text { gemiddeld } \\
\text { klein } \\
\text { erg groot } \\
\text { klein } \\
\text { klein } \\
\text { gemiddeld } \\
\text { klein } \\
\text { gemiddeld } \\
\text { gemiddeld } \\
\text { erg klein } \\
\text { erg groot }\end{array}$ \\
\hline
\end{tabular}

Bron: De Graaf e.a./ROA 
Tabel 3.8

Overzicht van perspectiefrijke omscholingsmogelijkheden naar beroepssegment

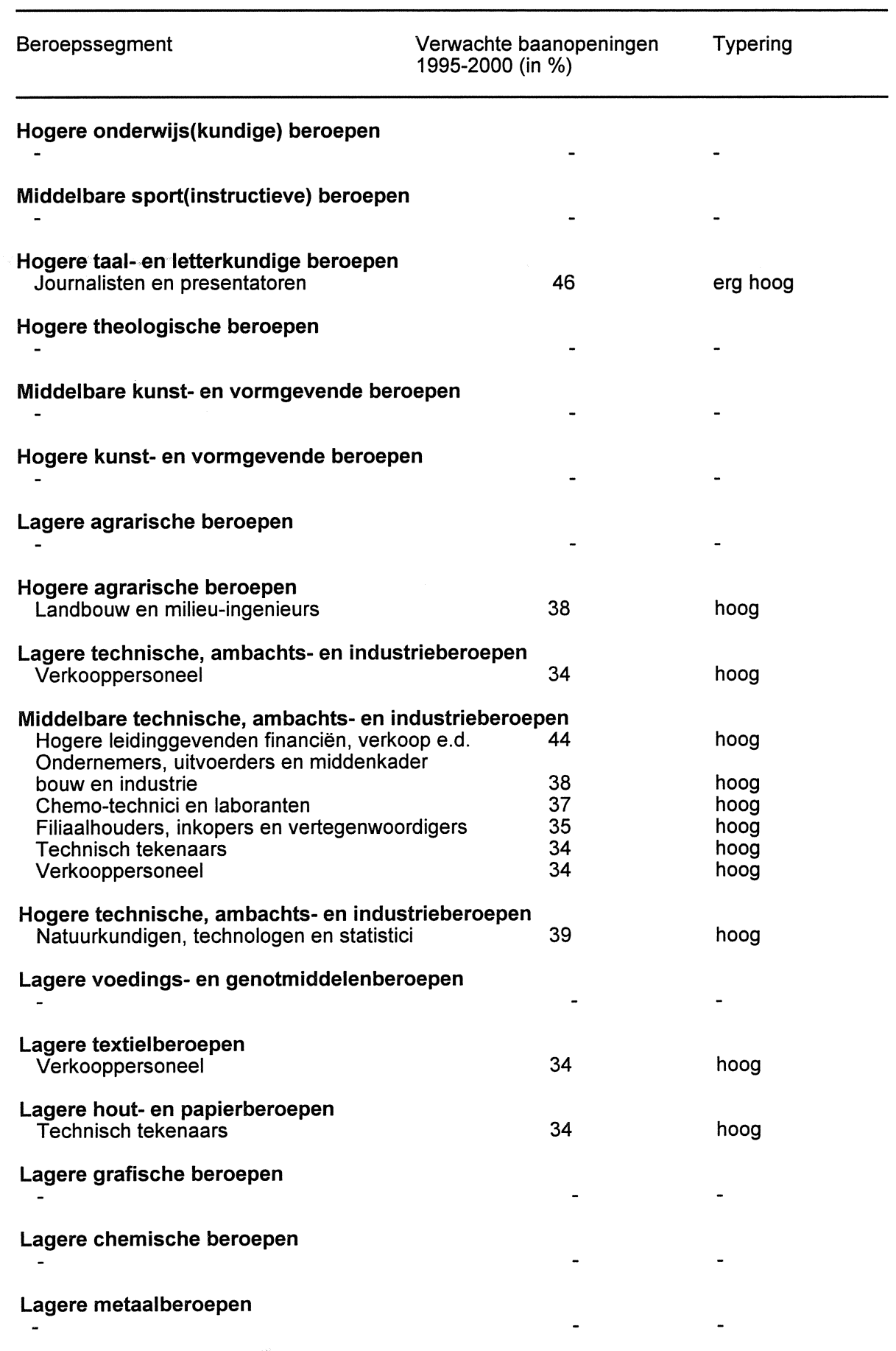


Tabel 3.8 (vervolg)

Overzicht van perspectiefrijke omscholingsmogelijkheden naar beroepssegment

\begin{tabular}{|c|c|c|}
\hline \multicolumn{2}{|c|}{$\begin{array}{l}\text { Verwachte baanopeningen } \\
1995-2000 \text { (in \%) }\end{array}$} & \multirow[t]{2}{*}{ Typering } \\
\hline Middelbare metaalberoepen & & \\
\hline $\begin{array}{l}\text { Hogere metaalberoepen } \\
\text { - }\end{array}$ & - & - \\
\hline $\begin{array}{l}\text { Lagere electrotechnische beroepen } \\
\text { Ondernemers, uitvoerders en middenkader } \\
\text { bouw en industrie } \\
\text { Technisch tekenaars } \\
\text { Verkooppersoneel }\end{array}$ & $\begin{array}{l}38 \\
34 \\
34\end{array}$ & $\begin{array}{l}\text { hoog } \\
\text { hoog } \\
\text { hoog }\end{array}$ \\
\hline $\begin{array}{l}\text { Middelbare electrotechnische beroepen } \\
\text { Elektrotechnische constructeurs en ingenieurs } \\
\text { Elektrotechnische opzichters en uitvoerders }\end{array}$ & $\begin{array}{l}39 \\
33\end{array}$ & $\begin{array}{l}\text { hoog } \\
\text { hoog }\end{array}$ \\
\hline $\begin{array}{l}\text { Hogere electrotechnische beroepen } \\
\text { Elektrotechnische constructeurs en ingenieurs } \\
\text { Elektrotechnische opzichters en uitvoerders }\end{array}$ & $\begin{array}{l}39 \\
33\end{array}$ & $\begin{array}{l}\text { hoog } \\
\text { hoog }\end{array}$ \\
\hline $\begin{array}{l}\text { Lagere bouwmaterialen-, glas- en aardewerkb } \\
\text { Verkooppersoneel }\end{array}$ & $\begin{array}{r}\text { pen } \\
34\end{array}$ & hoog \\
\hline $\begin{array}{l}\text { Lagere bouw- en installatieberoepen } \\
\text { Ondernemers, uitvoerders en middenkader } \\
\text { bouw en industrie } \\
\text { Technisch tekenaars }\end{array}$ & $\begin{array}{l}38 \\
34\end{array}$ & $\begin{array}{l}\text { hoog } \\
\text { hoog }\end{array}$ \\
\hline $\begin{array}{l}\text { Middelbare bouw- en installatieberoepen } \\
\text { Ondernemers, uitvoerders en middenkader } \\
\text { bouw en industrie } \\
\text { Chemo-technici en laboranten } \\
\text { Technisch tekenaars }\end{array}$ & $\begin{array}{l}38 \\
37 \\
34\end{array}$ & $\begin{array}{l}\text { hoog } \\
\text { hoog } \\
\text { hoog }\end{array}$ \\
\hline Hogere bouw- en installatieberoepen & - & - \\
\hline $\begin{array}{l}\text { Lagere transportberoepen } \\
\text { Verkooppersoneel }\end{array}$ & 34 & hoog \\
\hline $\begin{array}{l}\text { Lagere maritieme e.a. waterwegtransportberoe } \\
\text { - }\end{array}$ & - & - \\
\hline $\begin{array}{l}\text { Middelbare maritieme e.a. waterwegtransportb } \\
\text { - }\end{array}$ & pen & - \\
\hline $\begin{array}{l}\text { Lagere rail- en wegtransportberoepen } \\
\text { Verkooppersoneel }\end{array}$ & 34 & hoog \\
\hline Middelbare lucht- en overige transportberoepe & & \\
\hline $\begin{array}{l}\text { Middelbare medische en paramedische beroep } \\
\text { Verpleegkundigen } \\
\text { Leerling-verpleegkundigen, zieken- } \\
\text { en kraamverzorgenden } \\
\text { Dokters-, tandarts- en dierenartsassistenten }\end{array}$ & $\begin{array}{l}42 \\
42 \\
36\end{array}$ & $\begin{array}{l}\text { hoog } \\
\text { hoog } \\
\text { hoog }\end{array}$ \\
\hline
\end{tabular}


Tabel 3.8 (vervolg)

Overzicht van perspectiefrijke omscholingsmogelijkheden naar beroepssegment

\begin{tabular}{lll}
\hline Beroepssegment & $\begin{array}{l}\text { Verwachte baanopeningen } \\
1995-2000 \text { (in \%) }\end{array}$ & Typering \\
& &
\end{tabular}

\section{Hogere medische en paramedische beroepen}

Artsen, medische specialisten en apothekers

Fysio-, arbeids-, e.a. bewegingstherapeuten

Analisten en laboranten

Tandheelkundigen

$\begin{array}{ll}38 & \text { hoog } \\ 42 & \text { hoog } \\ 34 & \text { hoog } \\ 33 & \text { hoog }\end{array}$

Hogere economisch-administratieve beroepen

Programmeurs en systeemanalisten

Journalisten en presentatoren

Economen en accountants

Hogere leidinggevenden financien, verkoop e.d.

Ondernemers, uitvoerders en middenkader

bouw en industrie

Chemo-technici en laboranten

Filiaalhouders, inkopers en vertegenwoordigers

Technisch tekenaars

Verkooppersoneel

Bibliothecarissen en archivarissen

Maatschappelijk werkers

$\begin{array}{ll}73 & \text { erg hoog } \\ 46 & \text { erg hoog } \\ 46 & \text { erg hoog } \\ 44 & \text { hoog } \\ & \\ 38 & \text { hoog } \\ 37 & \text { hoog } \\ 35 & \text { hoog } \\ 34 & \text { hoog } \\ 34 & \text { hoog } \\ 34 & \text { hoog } \\ 32 & \text { hoog }\end{array}$

Lagere administratieve beroepen

Ondernemers, uitvoerders en middenkader bouw en industrie

Filiaalhouders, inkopers en vertegenwoordigers

Technisch tekenaars

Verkooppersoneel

hoog

hoog

hoog

Middelbare administratieve beroepen

Programmeurs en systeemanalisten

Economen en accountants

Journalisten en presentatoren

Hogere leidinggevenden financin, verkoop e.d.

Ondernemers, uitvoerders en middenkader bouw en industrie

Chemo-technici en laboranten

Filiaalhouders, inkopers en vertegenwoordigers

Technisch tekenaars

Verkooppersoneel

hoog

hoog

Hogere administratieve beroepen

Programmeurs en systeemanalisten

Economen en accountants

Journalisten en presentatoren

Hogere leidinggevenden financin, verkoop e.d.

hoog

hoog

hoog

Lagere commerciele beroepen

Ondernemers, uitvoerders en middenkader bouw en industrie

Filiaalhouders, inkopers en vertegenwoordigers

Technisch tekenaars

Verkooppersoneel

erg hoog

erg hoog

erg hoog

hoog

Middelbare commerciele beroepen

Hogere leidinggevenden financin, verkoop e.d.

Ondernemers, uitvoerders en middenkader bouw

en industrie

Chemo-technici en laboranten

Filiaalhouders, inkopers en vertegenwoordigers 
Tabel 3.8 (vervolg)

Overzicht van perspectiefrijke omscholingsmogelijkheden naar beroepssegment

\begin{tabular}{|c|c|c|}
\hline Beroepssegment & $\begin{array}{l}\text { baanopeningen } \\
\text { (in \%) }\end{array}$ & Typering \\
\hline $\begin{array}{l}\text { Technisch tekenaars } \\
\text { Verkooppersoneel }\end{array}$ & $\begin{array}{l}34 \\
34\end{array}$ & $\begin{array}{l}\text { hoog } \\
\text { hoog }\end{array}$ \\
\hline $\begin{array}{l}\text { Hogere bestuurlijke en juridische beroepen } \\
\text { Beleidsmedewerkers en hoofdambtenaren }\end{array}$ & 33 & hoog \\
\hline $\begin{array}{l}\text { Middelbare sociaal-culturele beroepen } \\
\text { Programmeurs en systeemanalisten } \\
\text { Economen en accountants } \\
\text { Journalisten en presentatoren } \\
\text { Hogere leidinggevenden financin, verkoop e.d. } \\
\text { Bibliothecarissen en archivarissen } \\
\text { Maatschappelijk werkers }\end{array}$ & $\begin{array}{l}73 \\
46 \\
46 \\
44 \\
34 \\
32\end{array}$ & $\begin{array}{l}\text { erg hoog } \\
\text { erg hoog } \\
\text { erg hoog } \\
\text { hoog } \\
\text { hoog } \\
\text { hoog }\end{array}$ \\
\hline $\begin{array}{l}\text { Hogere sociaal-culturele beroepen } \\
\text { Journalisten en presentatoren } \\
\text { Hogere leidinggevenden financin, verkoop e.d. } \\
\text { Bibliothecarissen en archivarissen } \\
\text { Maatschappelijk werkers }\end{array}$ & $\begin{array}{l}46 \\
44 \\
34 \\
32\end{array}$ & $\begin{array}{l}\text { erg hoog } \\
\text { hoog } \\
\text { hoog } \\
\text { hoog }\end{array}$ \\
\hline $\begin{array}{l}\text { Lagere horecaberoepen } \\
\text { Verkooppersoneel }\end{array}$ & 34 & hoog \\
\hline $\begin{array}{l}\text { Middelbare horecaberoepen } \\
\text { Verkooppersoneel }\end{array}$ & 34 & hoog \\
\hline $\begin{array}{l}\text { Lagere verzorgende beroepen } \\
\text { Verkooppersoneel }\end{array}$ & 34 & hoog \\
\hline $\begin{array}{l}\text { Middelbare verzorgende beroepen } \\
\text { - }\end{array}$ & - & - \\
\hline $\begin{array}{l}\text { Mddelbare politie-, brandweer- en bewakingst } \\
\text { - }\end{array}$ & pen & - \\
\hline Mddelbare militaire beroepen & - & - \\
\hline
\end{tabular}

Bron: ROA 
RISICOPROFIELEN NAAR BEROEP 
.... 
Het risico op verlies van werk naar beroepssegment: hoogste IT-index
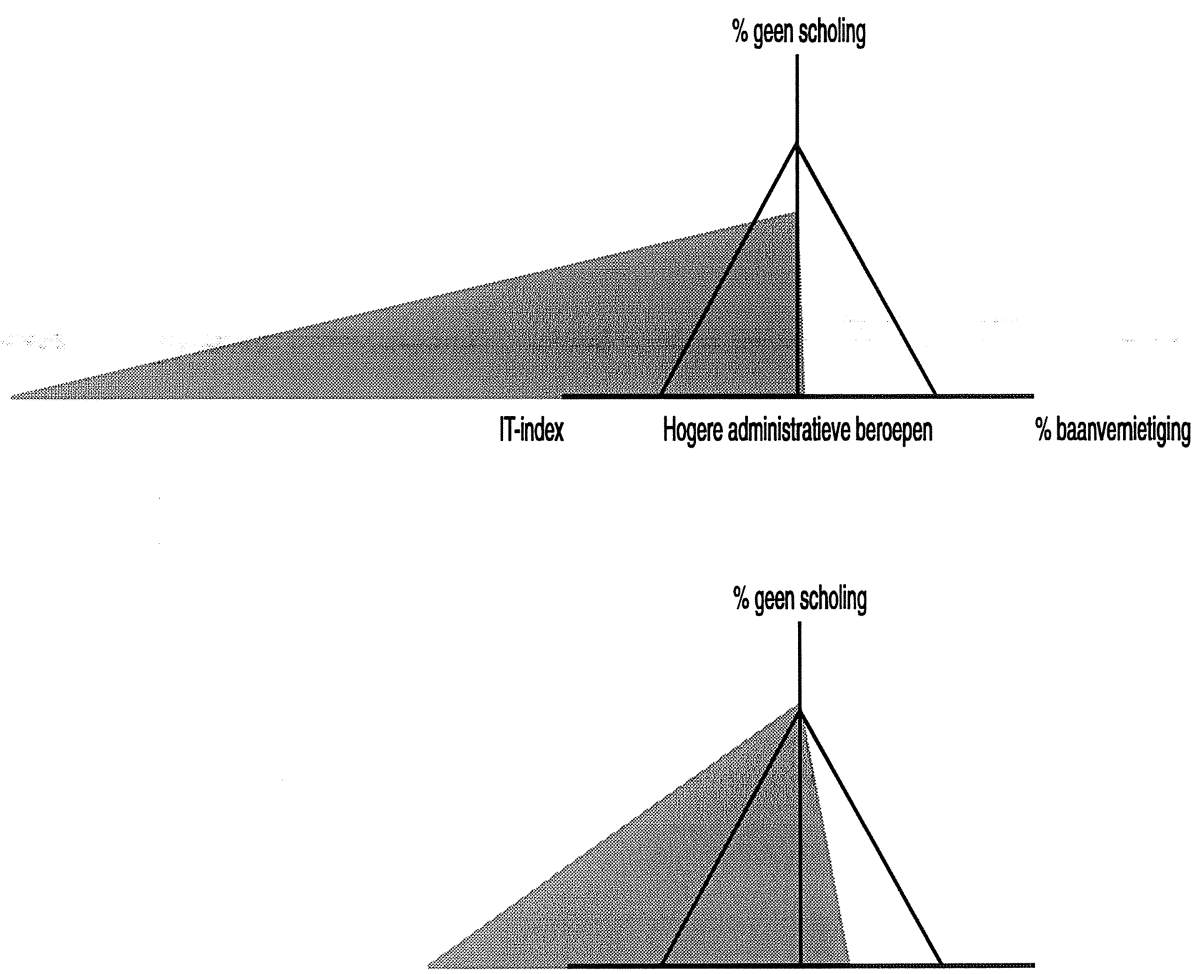

IT-index Hogere technische, ambachts- en industrieberoepen \% baanvemietiging

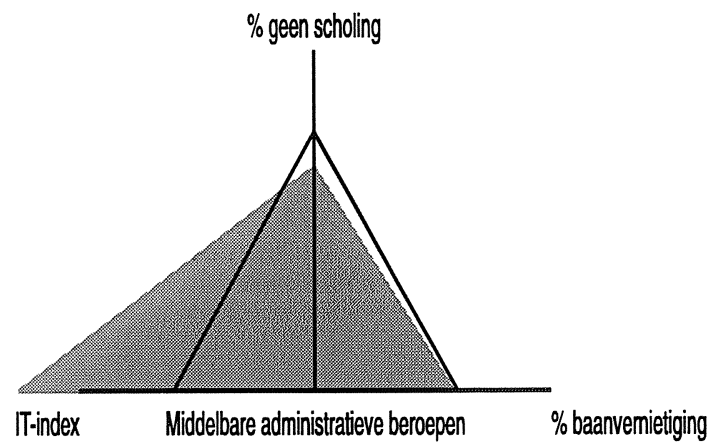



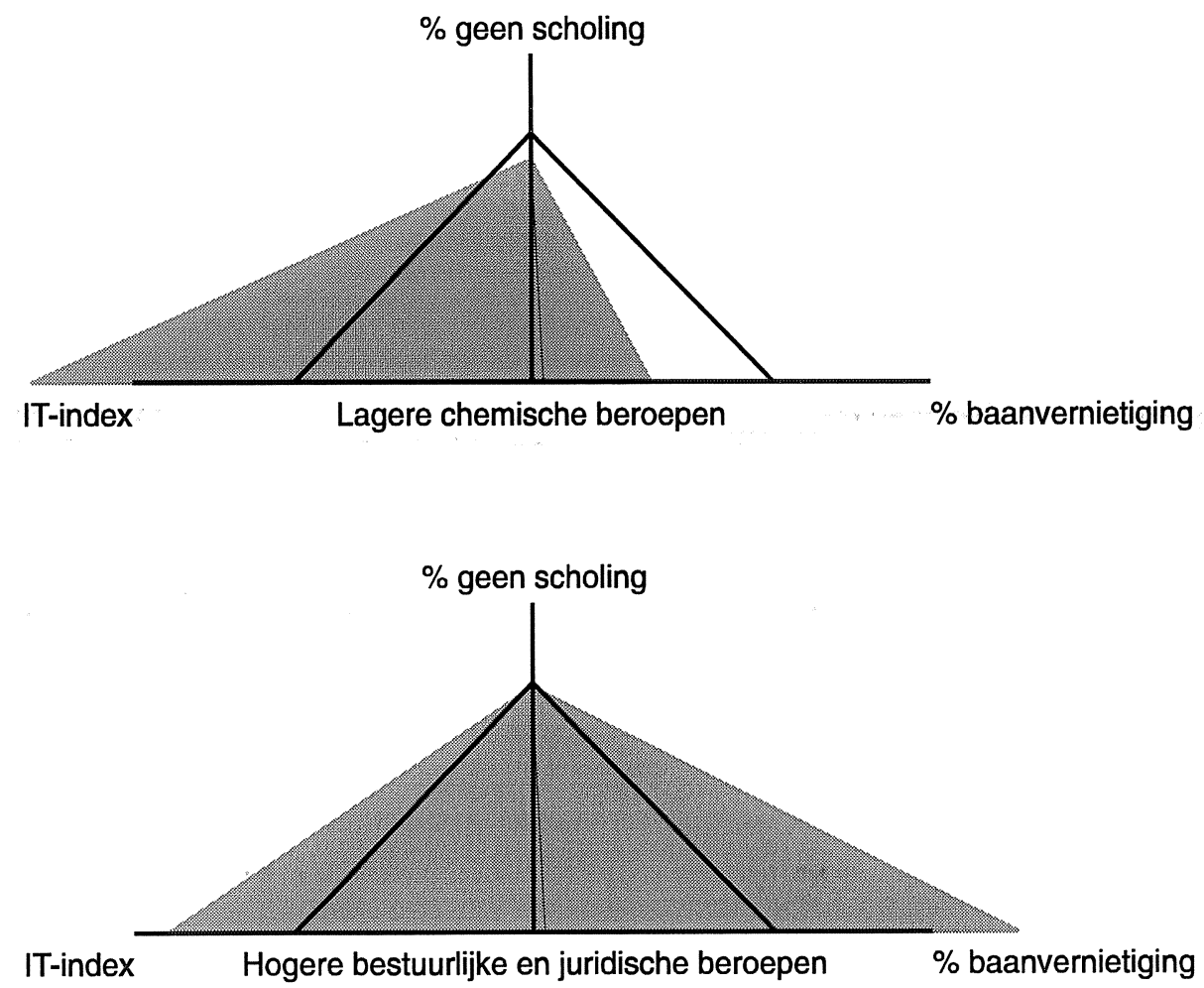
Het risico op verlies van werk naar beroepssegment: hoogste baanvernietiging
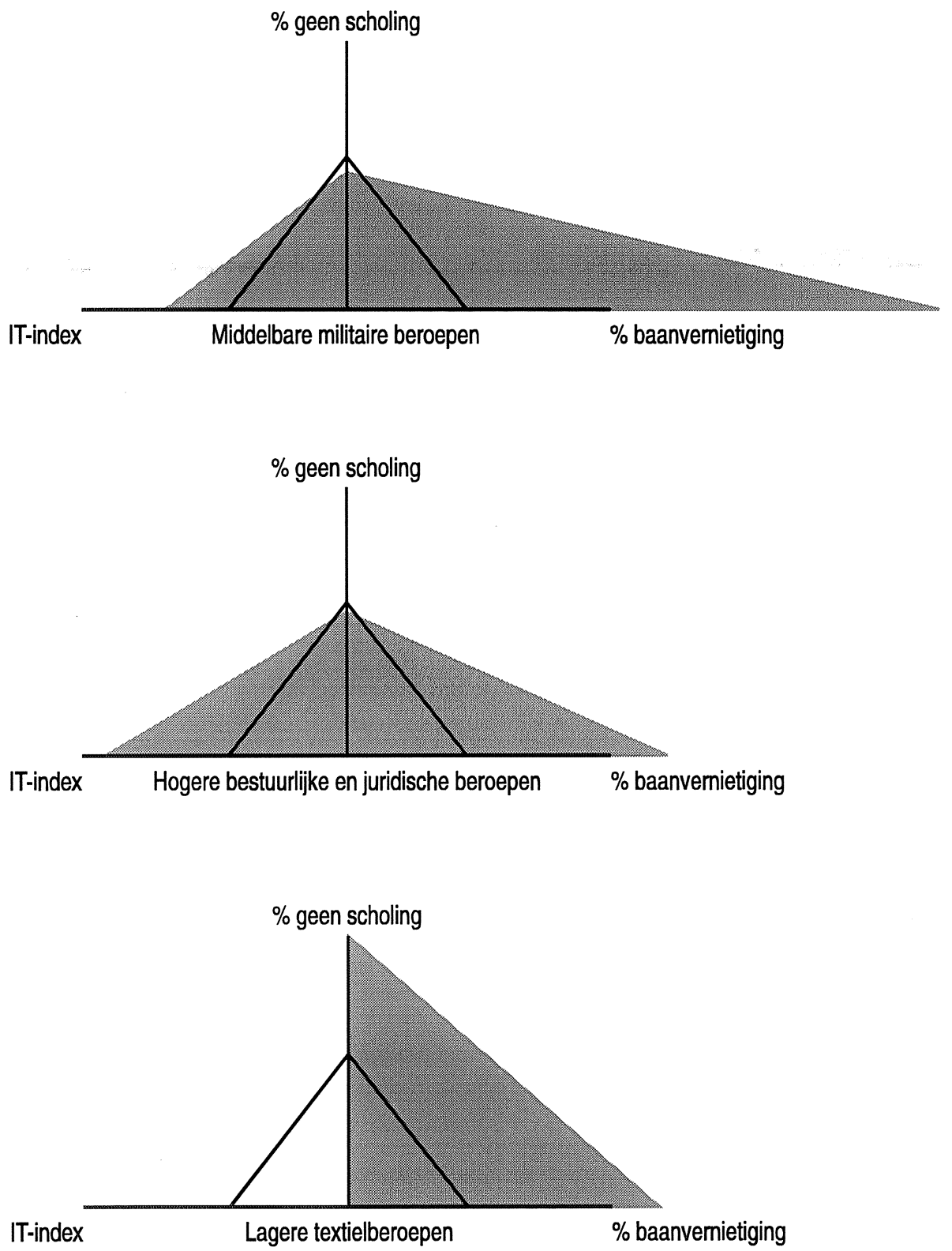


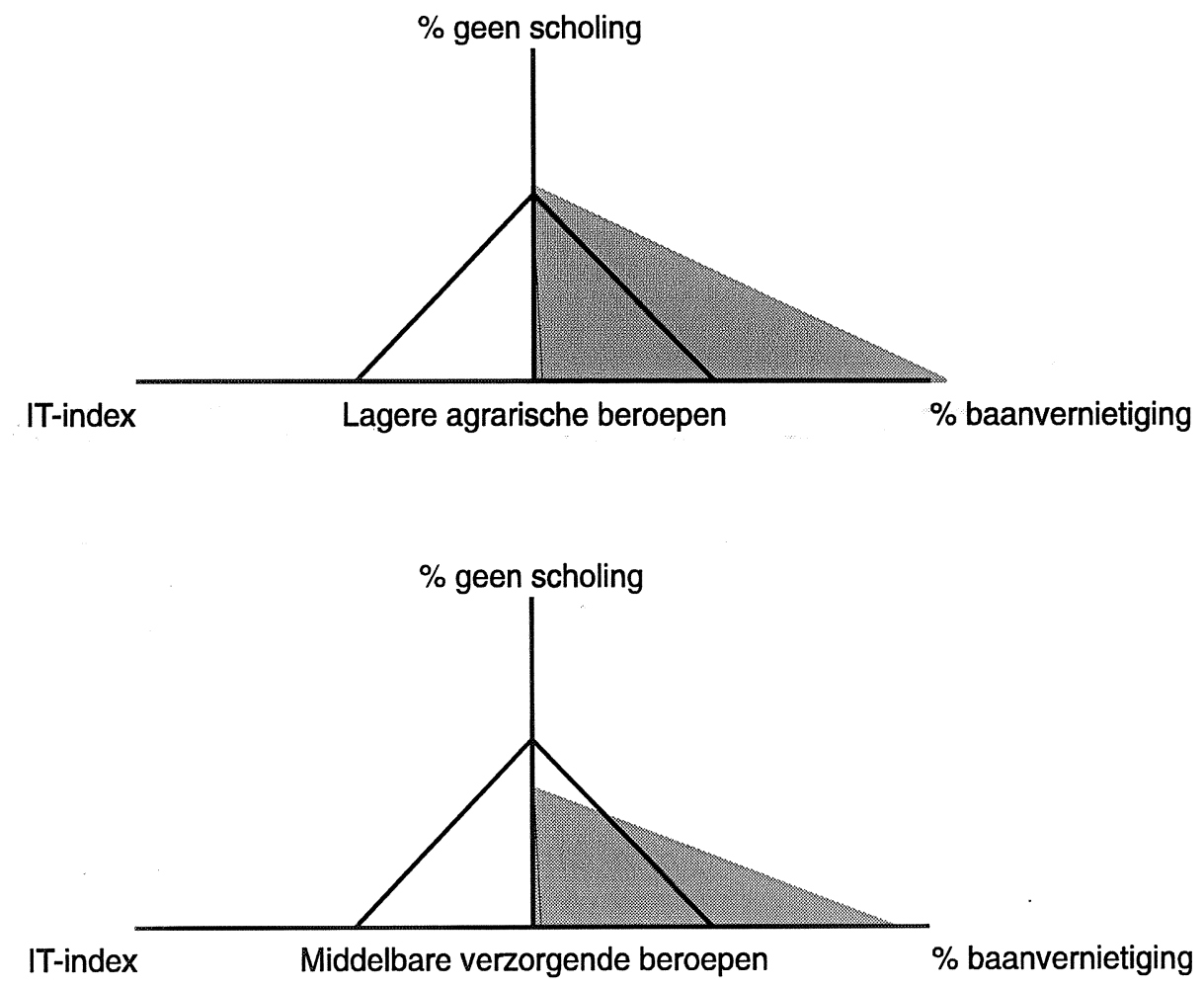


Het risico op verlies van werk naar beroepssegment: hoogste tekort aan scholing
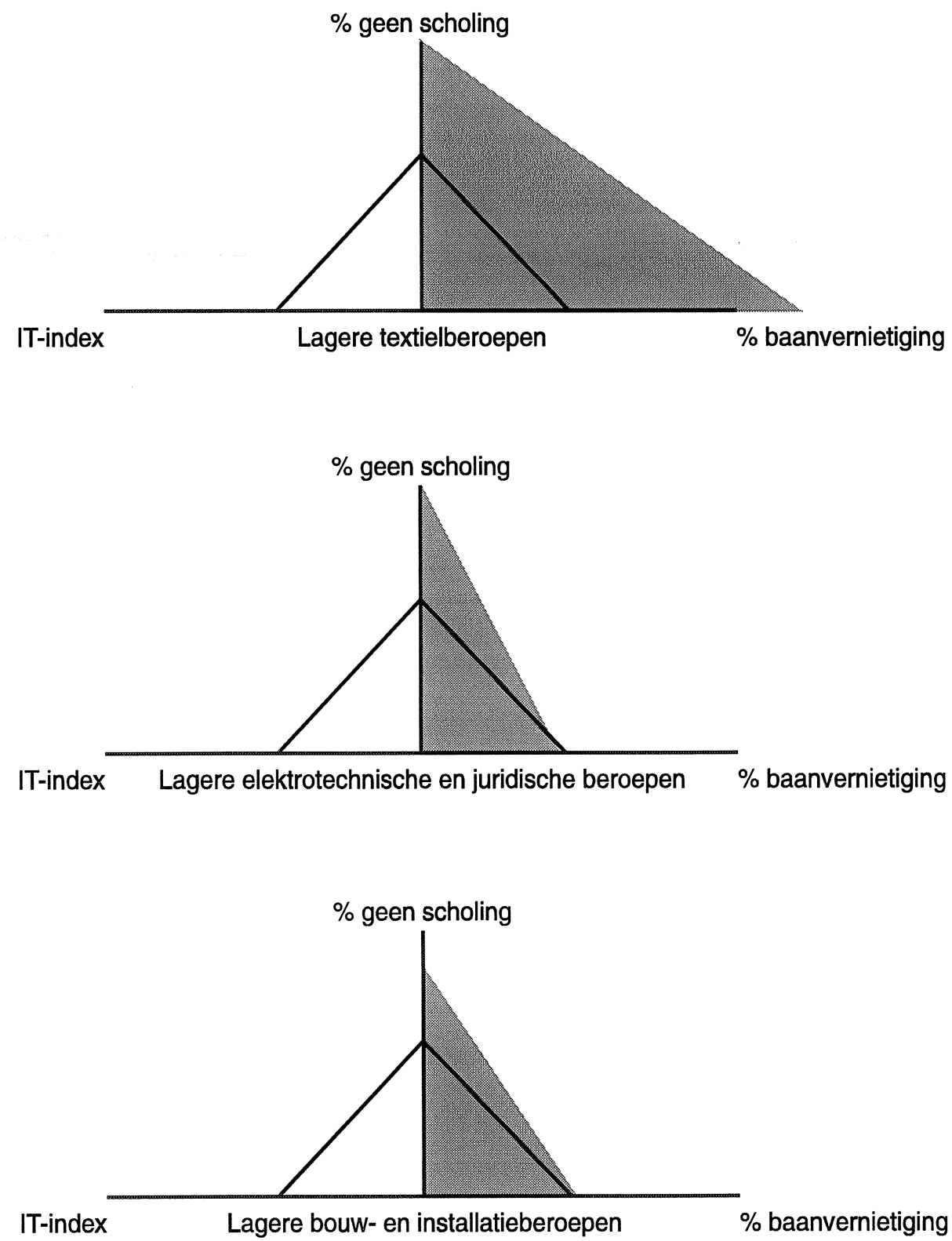

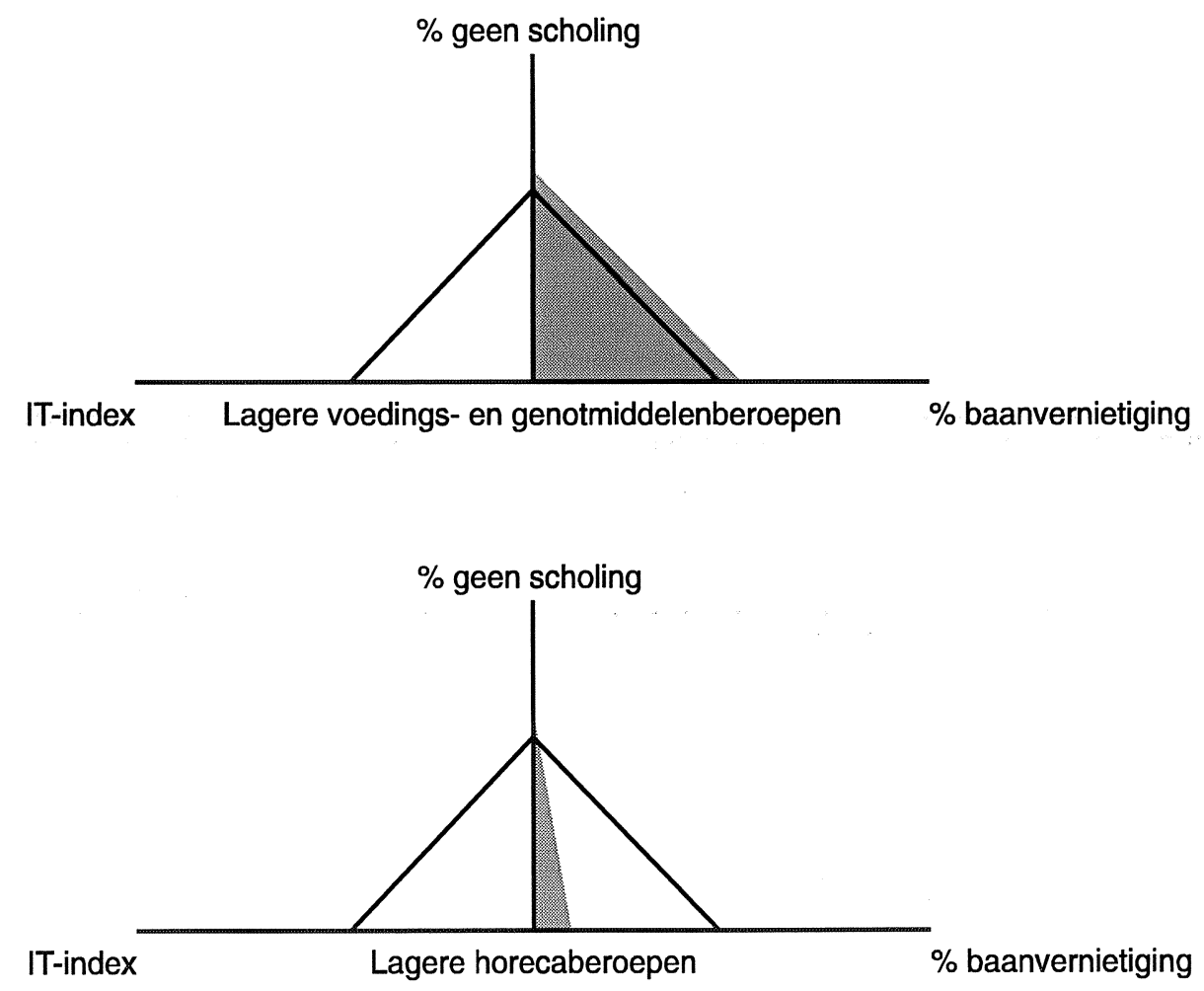
INFORMATIE OVER OPLEIDINGEN 
$\ldots$ 
Tabel 4.1

Informatietechnologie naar opleidingstype, 1993-1994

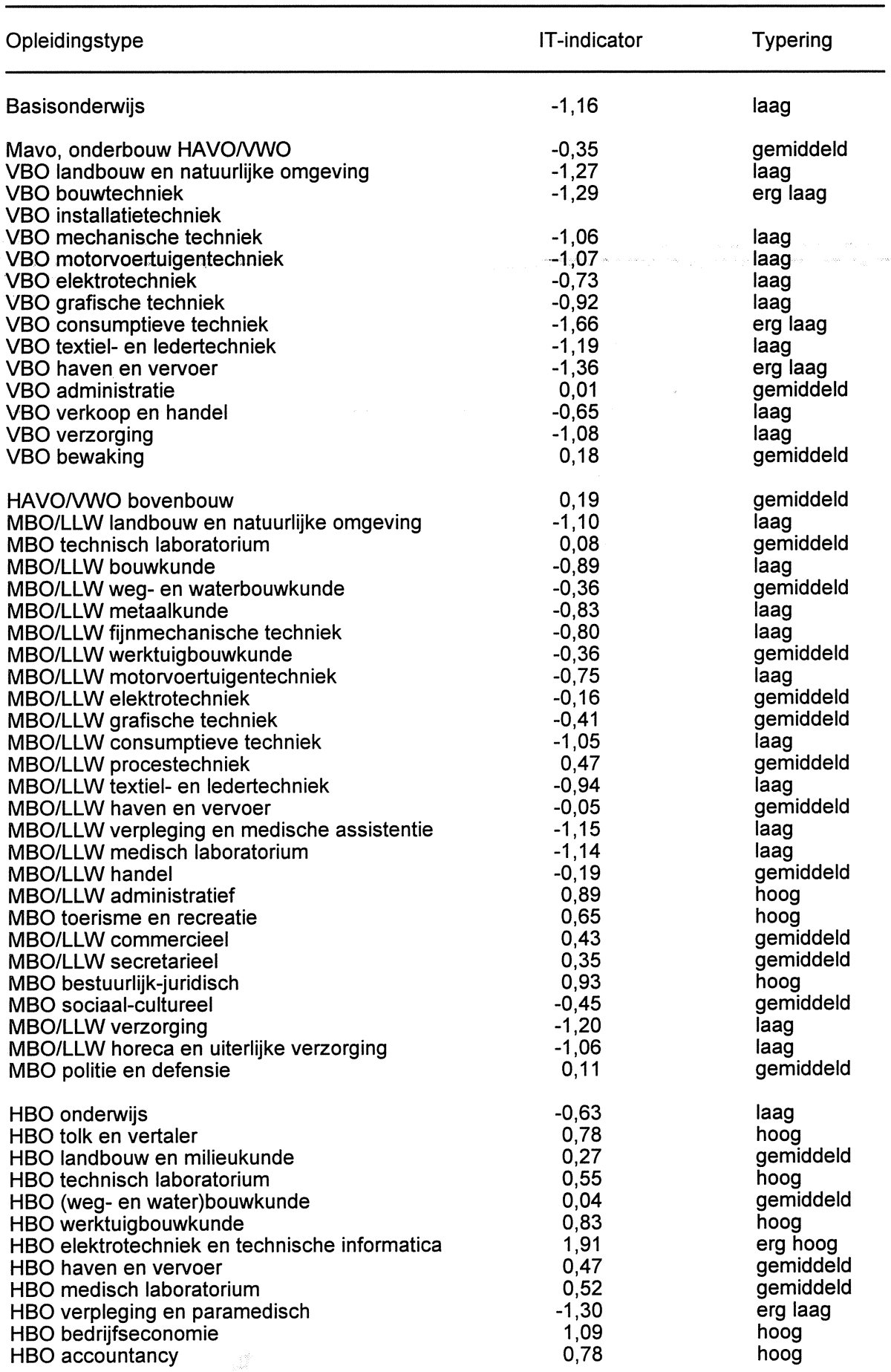


Tabel 4.1 (vervolg)

Informatietechnologie naar opleidingstype, 1993-1994

\begin{tabular}{lcl}
\hline Opleidingstype & IT-indicator & Typering \\
\hline HBO bedrijfsinformatica & 3,39 & erg hoog \\
HBO toerisme en recreatie & 0,52 & gemiddeld \\
HBO commerciële economie & 0,38 & gemiddeld \\
HBO technische bedriffskunde & 1,56 & erg hoog \\
HBO bestuurlijk-juridisch & 0,69 & hoog \\
HBO sociaal-cultureel & $-0,08$ & gemiddeld \\
HBO kunst & $-0,52$ & gemiddeld \\
HBO politie en defensie & 0,28 & gemiddeld \\
WO letteren & 0,22 & gemiddeld \\
WO theologisch & $-0,73$ & laag \\
WO landbouw en milieukunde & 0,34 & gemiddeld \\
WO wiskunde en natuurwetenschappen & 0,79 & hoog \\
WO (weg- en water)bouwkunde & $-0,38$ & gemiddeld \\
WO werktuigbouwkunde & 0,85 & hoog \\
WO elektrotechniek en technische informatica & 2,08 & erg hoog \\
WO dier-, genees- en tandheelkunde & 0,83 & hoog \\
WO farmacie & 0,89 & hoog \\
WO econom(etr)ie en accountancy & 0,78 & hoog \\
WO bedrijfskunde & 0,53 & hoog \\
WO informatica & 3,62 & erg hoog \\
WO juridisch & 0,51 & gemiddeld \\
WO bestuurlijk & 0,68 & hoog \\
WO sociaal-cultureel & 0,33 & gemiddeld \\
WO kunst & $-0,48$ & gemiddeld \\
& & \\
\hline B & &
\end{tabular}

Bron: De Graaf e.a./CBS/ROA 
Tabel 4.2

Verwachte uitbreidingsvraag naar opleidingstype, 1995-2000

\begin{tabular}{llll}
\hline Opleidingstype & Aantal Totaal & $\begin{array}{c}\text { Gemiddeld Typering } \\
\%\end{array}$ \\
\hline
\end{tabular}

\section{BASISONDERWIJS}

Basisonderwijs

$\begin{array}{llll}-66.300 & -13 & -2,8 & \text { erg laag }\end{array}$

MAVO, VBO

MAVO, onderbouw HAVOMWO

$$
\begin{array}{r}
-18.400 \\
-7.100 \\
-8.300 \\
-500 \\
-7.800 \\
-2.700 \\
-2.900 \\
-200 \\
-700 \\
-1.100 \\
-900 \\
-3.800 \\
-500 \\
-6.400 \\
3.200
\end{array}
$$

VBO landbouw en natuurlijke omgeving

VBO bouwtechniek

VBO installatietechniek

VBO mechanische techniek

VBO motorvoertuigentechniek

VBO elektrotechniek

VBO grafische techniek

VBO consumptieve techniek

VBO textiel- en ledertechniek

VBO haven en vervoer

VBO administratie

VBO verkoop en handel

VBO verzorging

VBO bewaking

$\begin{array}{lll}-5 & -0,9 & \text { laag } \\ -9 & -1,9 & \text { erg laag } \\ -6 & -1,2 & \text { laag } \\ -6 & -1,1 & \text { laag } \\ -6 & -1,2 & \text { laag } \\ -5 & -1,1 & \text { laag } \\ -5 & -1,0 & \text { laag } \\ -4 & -0,7 & \text { laag } \\ -4 & -0,7 & \text { laag } \\ -5 & -0,9 & \text { laag } \\ -3 & -0,5 & \text { laag } \\ -6 & -1,3 & \text { laag } \\ -2 & -0,3 & \text { laag } \\ -3 & -0,6 & \text { laag } \\ 31 & 5,5 & \text { erg hoog }\end{array}$

\section{HAVO/VWO, MBO/LLW}

HAVONWO bovenbouw

$\mathrm{MBO} / \mathrm{LLW}$ landbouw en natuurlijke omgeving

MBO technisch laboratorium

MBO/LLW bouwkunde

-2.100
1.200

1200

MBO/LLW weg- en waterbouwkunde $\quad 1.200$

MBO/LLW metaalkunde

1.200
2.300

MBO/LLW fijnmechanische techniek

$\mathrm{MBO} / \mathrm{LLW}$ werktuigbouwkunde

900

5.000

2.100

MBO/LLW motorvoertuigentechniek

8.700

$\mathrm{MBO} / \mathrm{LLW}$ grafische techniek

MBO/LLW consumptieve techniek

2.200

2.000

900

MBO/LLW textiel- en ledertechniek

MBO/LLW haven en vervoer

1.600

2600

MBO/LLW verpleging en medische assistentie $\quad 16.400$

$\mathrm{MBO} / \mathrm{LLW}$ medisch laboratorium

2.900

MBO/LLW handel

MBO/LLW administratief

MBO toerisme en recreatie

MBO/LLW commercieel

MBO/LLW secretarieel

MBO bestuurlijk-juridisch

MBO sociaal-culturee

MBO/LLW verzorging

MBO/LLW horeca en uiterlijke verzorging

100

2.900

300

2.100

700

$-400$

800

9.100

1.800

MBO politie en defensie

13.500

$\begin{array}{rrl}7 & 1,3 & \text { gemiddeld } \\ -2 & -0,3 & \text { laag } \\ 9 & 1,7 & \text { gemiddeld } \\ 3 & 0,6 & \text { laag } \\ 6 & 1,1 & \text { gemiddeld } \\ 4 & 0,8 & \text { gemiddeld } \\ 6 & 1,2 & \text { gemiddeld } \\ 6 & 1,1 & \text { gemiddeld } \\ 3 & 0,7 & \text { laag } \\ 6 & 1,2 & \text { gemiddeld } \\ 6 & 1,2 & \text { gemiddeld } \\ 5 & 1,0 & \text { gemiddeld } \\ 5 & 1,0 & \text { gemiddeld } \\ 4 & 0,9 & \text { gemiddeld } \\ 6 & 1,1 & \text { gemiddeld } \\ 9 & 1,7 & \text { gemiddeld } \\ 10 & 2,0 & \text { gemiddeld } \\ 7 & 1,3 & \text { gemiddeld } \\ 3 & 0,6 & \text { laag } \\ 2 & 0,4 & \text { laag } \\ 6 & 1,2 & \text { gemiddeld } \\ 1 & 0,1 & \text { laag } \\ -1 & -0,2 & \text { laag } \\ 2 & 0,3 & \text { laag } \\ 4 & 0,8 & \text { gemiddeld } \\ 3 & 0,6 & \text { laag } \\ 17 & 3,1 & \text { hoog }\end{array}$


Tabel 4.2 (vervolg)

Verwachte uitbreidingsvraag naar opleidingstype, 1995-2000

\begin{tabular}{|c|c|c|c|c|}
\hline Opleidingstype & Aantal & Totaal & $\begin{array}{l}\text { Gemiddeld } \\
\%\end{array}$ & $\begin{array}{l}\text { Typering } \\
\text { jaarlijks \% }\end{array}$ \\
\hline \multicolumn{5}{|l|}{ HBO } \\
\hline $\begin{array}{l}\text { HBO onderwijs } \\
\text { HBO tolk en vertaler } \\
\text { HBO landbouw en milieukunde } \\
\text { HBO technisch laboratorium } \\
\text { HBO (weg- en water)bouwkunde } \\
\text { HBO werktuigbouwkunde } \\
\text { HBO elektrotechniek en technische informatica } \\
\text { HBO haven en vervoer } \\
\text { HBO medisch laboratorium } \\
\text { HBO verpleging en paramedisch } \\
\text { HBO bedrijfseconomie } \\
\text { HBO accountancy } \\
\text { HBO bedrijfsinformatica } \\
\text { HBO toerisme en recreatie } \\
\text { HBO commerciële economie } \\
\text { HBO technische bedrijfsunde } \\
\text { HBO bestuurlijk-juridisch } \\
\text { HBO sociaal-cultureel } \\
\text { HBO kunst } \\
\text { HBO politie en defensie }\end{array}$ & $\begin{array}{r}18.500 \\
700 \\
2.700 \\
6.000 \\
5.300 \\
5.100 \\
11.200 \\
4.300 \\
3.400 \\
14.400 \\
3.900 \\
7.000 \\
10.400 \\
500 \\
3.800 \\
2.800 \\
1.900 \\
14.100 \\
7.300 \\
200\end{array}$ & $\begin{array}{r}7 \\
9 \\
14 \\
22 \\
15 \\
17 \\
27 \\
15 \\
16 \\
17 \\
18 \\
25 \\
36 \\
7 \\
19 \\
22 \\
7 \\
12 \\
15 \\
2\end{array}$ & $\begin{array}{l}1,4 \\
1,7 \\
2,7 \\
4,0 \\
2,7 \\
3,2 \\
4,8 \\
2,9 \\
2,9 \\
3,2 \\
3,3 \\
4,5 \\
6,3 \\
1,4 \\
3,5 \\
4,0 \\
1,4 \\
2,3 \\
2,9 \\
0,5\end{array}$ & $\begin{array}{l}\text { gemiddeld } \\
\text { gemiddeld } \\
\text { hoog } \\
\text { hoog } \\
\text { hoog } \\
\text { hoog } \\
\text { erg hoog } \\
\text { hoog } \\
\text { hoog } \\
\text { hoog } \\
\text { hoog } \\
\text { erg hoog } \\
\text { erg hoog } \\
\text { gemiddeld } \\
\text { hoog } \\
\text { hoog } \\
\text { gemiddeld } \\
\text { gemiddeld } \\
\text { hoog } \\
\text { laag }\end{array}$ \\
\hline \multicolumn{5}{|l|}{ WO } \\
\hline $\begin{array}{l}\text { WO letteren } \\
\text { WO theologisch } \\
\text { WO landbouw en milieukunde } \\
\text { WO wiskunde en natuurwetenschappen } \\
\text { WO (weg- en water)bouwkunde } \\
\text { WO werktuigbouwkunde } \\
\text { WO elektrotechniek en technische informatica } \\
\text { WO dier-, genees- en tandheelkunde } \\
\text { WO farmacie } \\
\text { WO econom(etr)ie en accountancy } \\
\text { WO bedrijfskunde } \\
\text { WO informatica } \\
\text { WO juridisch } \\
\text { WO bestuurlijk } \\
\text { WO sociaal-cultureel } \\
\text { WO kunst }\end{array}$ & $\begin{array}{r}7.000 \\
700 \\
2.100 \\
9.400 \\
3.700 \\
1.900 \\
4.200 \\
8.800 \\
700 \\
14.900 \\
3.200 \\
1.500 \\
4.000 \\
2.400 \\
14.800 \\
900\end{array}$ & $\begin{array}{r}17 \\
13 \\
17 \\
22 \\
20 \\
22 \\
31 \\
16 \\
15 \\
34 \\
32 \\
34 \\
8 \\
24 \\
18 \\
10\end{array}$ & $\begin{array}{l}3,1 \\
2,5 \\
3,2 \\
4,1 \\
3,7 \\
4,0 \\
5,5 \\
3,1 \\
2,8 \\
6,0 \\
5,7 \\
6,1 \\
1,6 \\
4,4 \\
3,4 \\
2,0\end{array}$ & $\begin{array}{l}\text { hoog } \\
\text { gemiddeld } \\
\text { hoog } \\
\text { hoog } \\
\text { hoog } \\
\text { hoog } \\
\text { erg hoog } \\
\text { hoog } \\
\text { hoog } \\
\text { erg hoog } \\
\text { erg hoog } \\
\text { erg hoog } \\
\text { gemiddeld } \\
\text { erg hoog } \\
\text { hoog } \\
\text { gemiddeld }\end{array}$ \\
\hline
\end{tabular}

Bron: ROA 
Tabel 4.3

Componenten van de werkgelegenheidsverschuivingen naar opleidingsniveau (netto-effecten), $1995-2000$

\begin{tabular}{lrrrrr}
\hline & $\begin{array}{r}\text { Bedrijfs- } \\
\text { sectoreffect }\end{array}$ & $\begin{array}{r}\text { Beroeps- } \\
\text { effect }\end{array}$ & $\begin{array}{r}\text { Opleidings- } \\
\text { effect } \\
\text { (upgrading) }\end{array}$ & $\begin{array}{r}\text { Substitutie- } \\
\text { effect }\end{array}$ & Totaal \\
& $\%$ & $\%$ & $\%$ & $\%$ \\
\hline Basisonderwijs & 4,2 & $-4,2$ & $-13,1$ & $-1,7$ & $-14,8$ \\
MAVO, VBO & 4,0 & $-3,1$ & $-5,4$ & $-3,2$ & $-7,7$ \\
HAVOMWO, MBO/LLW & 4,6 & $-1,0$ & 1,8 & $-0,7$ & 4,7 \\
HBO & 3,7 & 5,8 & 4,9 & 3,8 & 18,2 \\
WO & 3,7 & 7,1 & 9,3 & 7,2 & 27,3 \\
Totaal & 4,2 & 0 & 0 & 0 & 4,2 \\
& 4,2 & & & & \\
\hline
\end{tabular}

Bron: ROA 
Tabel 4.4

Opleidingseffect naar opleidingstype, 1995-2000 (gemiddeld jaarlijks percentage)

\begin{tabular}{|c|c|c|}
\hline \multicolumn{2}{|c|}{ Opleidingseffect $\%$} & $\begin{array}{r}\text { Totaal \% } \\
-3,1\end{array}$ \\
\hline $\begin{array}{l}\text { Basisonderwijs } \\
\text { Mavo, onderbouw HAVONWO } \\
\text { VBO landbouw en natuurlijke omgeving } \\
\text { VBO bouwtechniek } \\
\text { VBO installatietechniek } \\
\text { VBO mechanische techniek } \\
\text { VBO motorvoertuigentechniek } \\
\text { VBO elektrotechniek } \\
\text { VBO grafische techniek } \\
\text { VBO consumptieve techniek } \\
\text { VBO textiel- en ledertechniek } \\
\text { VBO haven en vervoer } \\
\text { VBO administratie } \\
\text { VBO verkoop en handel } \\
\text { VBO verzorging } \\
\text { VBO bewaking }\end{array}$ & $\begin{array}{r}-2,8 \\
-1,5 \\
-0,8 \\
-0,8 \\
0 \\
0 \\
-1,0 \\
-1,2 \\
-1,0 \\
-0,9 \\
-1,0 \\
-0,7 \\
-1,6 \\
-1,3 \\
-1,0 \\
4,9\end{array}$ & $\begin{array}{r}-3,1 \\
-1,2 \\
-3,3 \\
-2,1 \\
-2,4 \\
-2,0 \\
-2,0 \\
-1,4 \\
-0,9 \\
-1,6 \\
-2,0 \\
-1,8 \\
-1,6 \\
-0,9 \\
-1,5 \\
7,4\end{array}$ \\
\hline $\begin{array}{l}\text { HAVO/NWO bovenbouw } \\
\text { MBO/LLW landbouw en natuurlijke omgeving } \\
\text { MBO technisch laboratorium } \\
\text { MBO/LLW bouwkunde } \\
\text { MBO/LLW weg- en waterbouwkunde } \\
\text { MBO/LLW metaalkunde } \\
\text { MBO/LLW fijnmechanische techniek } \\
\text { MBO/LLW werktuigbouwkunde } \\
\text { MBO/LLW motorvoertuigentechniek } \\
\text { MBO/LLW elektrotechniek } \\
\text { MBO/LLW grafische techniek } \\
\text { MBO/LLW consumptieve techniek } \\
\text { MBO/LLW procestechniek } \\
\text { MBO/LLW textiel- en ledertechniek } \\
\text { MBO/LLW haven en vervoer } \\
\text { MBO/LLW verpleging en medische assistentie } \\
\text { MBO/LLW medisch laboratorium } \\
\text { MBO/LLW handel } \\
\text { MBO/LLW administratief } \\
\text { MBO toerisme en recreatie } \\
\text { MBO/LLW commercieel } \\
\text { MBO/LLW secretarieel } \\
\text { MBO bestuurlijk-juridisch } \\
\text { MBO sociaal-cultureel } \\
\text { MBO/LLW verzorging } \\
\text { MBO/LLW horeca en uiterlijke verzorging } \\
\text { MBO politie en defensie }\end{array}$ & $\begin{array}{r}0,1 \\
0,8 \\
-0,4 \\
0,6 \\
0,2 \\
0,6 \\
0,4 \\
0,4 \\
0,5 \\
0,2 \\
0,3 \\
0,6 \\
0,5 \\
0,6 \\
0,7 \\
-0,1 \\
0,0 \\
0,3 \\
-0,1 \\
0,2 \\
0,1 \\
0,2 \\
-0,4 \\
-0,6 \\
0,5 \\
0,5 \\
3,4\end{array}$ & $\begin{array}{r}1,6 \\
-1,3 \\
2,5 \\
0,0 \\
1,2 \\
0,2 \\
0,9 \\
0,8 \\
0,3 \\
1,3 \\
0,9 \\
0,2 \\
0,7 \\
0,2 \\
0,7 \\
1,7 \\
1,9 \\
1,2 \\
1,1 \\
0,5 \\
1,4 \\
0,2 \\
0,2 \\
0,9 \\
0,3 \\
-0,2 \\
2,7\end{array}$ \\
\hline $\begin{array}{l}\text { HBO onderwijs } \\
\text { HBO tolk en vertaler } \\
\text { HBO landbouw en milieukunde } \\
\text { HBO technisch laboratorium } \\
\text { HBO (weg- en water)bouwkunde } \\
\text { HBO werktuigbouwkunde } \\
\text { HBO elektrotechniek en technische informatica } \\
\text { HBO haven en vervoer } \\
\text { HBO medisch laboratorium } \\
\text { HBO verpleging en paramedisch } \\
\text { HBO bedrijfseconomie } \\
\text { HBO accountancy } \\
\text { HBO bedrijfsinformatica } \\
\text { HBO toerisme en recreatie }\end{array}$ & $\begin{array}{l}0,5 \\
0,7 \\
1,1 \\
1,0 \\
1,0 \\
1,1 \\
0,9 \\
1,6 \\
0,6 \\
1,0 \\
1,3 \\
1,2 \\
0,7 \\
1,3\end{array}$ & $\begin{array}{l}1,6 \\
2,0 \\
3,4 \\
5,3 \\
4,2 \\
4,4 \\
6,6 \\
3,2 \\
3,2 \\
3,4 \\
4,3 \\
6,1 \\
8,3 \\
1,6\end{array}$ \\
\hline
\end{tabular}


Tabel 4.4 (vervolg)

Opleidingseffect naar opleidingstype, 1995-2000 (gemiddeld jaarlijks percentage)

\begin{tabular}{lcc}
\hline Opleidingstype & Opleidingseffect \% & Totaal \% \\
\hline HBO commerciële economie & 1,5 & 4,4 \\
HBO technische bedrijfskunde & 1,1 & 5,5 \\
HBO bestuurlijk-juridisch & 0,3 & 2,4 \\
HBO sociaal-cultureel & 0,8 & 3,4 \\
HBO kunst & 1,0 & 3,6 \\
HBO politie en defensie & 1,7 & 1,7 \\
WO letteren & 1,5 & 3,9 \\
WO theologisch & 1,2 & 3,2 \\
WO landbouw en milieukunde & 1,5 & 5,0 \\
WO wiskunde en natuurwetenschappen & 1,5 & 6,1 \\
WO (weg- en water)bouwkunde & 2,0 & 6,0 \\
WO werktuigbouwkunde & 1,9 & 6,1 \\
WO elektrotechniek en technische informatica & 2,0 & 7,8 \\
WO dier-, genees- en tandheelkunde & 0,5 & 3,4 \\
WO farmacie & 0,8 & 3,8 \\
WO econom(etr)ie en accountancy & 2,4 & 7,8 \\
WO bedrijfskunde & 2,6 & 7,5 \\
WO informatica & 2,2 & 8,2 \\
WO juridisch & 1,8 & 2,8 \\
WO bestuurlijk & 2,0 & 6,1 \\
WO sociaal-cultureel & 1,9 & 4,7 \\
WO kunst & 0,9 & 2,8 \\
\end{tabular}

Bron: ROA 
Tabel 4.5

Verwachte krimp-kengetallen opleidingstypen naar beroepssegment, 1995-2000

\begin{tabular}{lll}
\hline $\begin{array}{ll}\text { Baanvernietiging } \\
\text { in \% }\end{array}$ & $\begin{array}{l}\text { Rel. } \\
\text { uitbreidingsvraag } \\
\text { in \% }\end{array}$ & $\begin{array}{l}\text { Bijdrage aan } \\
\text { krimp }\end{array}$ \\
&
\end{tabular}

\section{Basisonderwijs}

lagere verzorgende beroepen

lagere bouw- en installatieberoepen

middelbare administratieve beroepen

lagere agrarische beroepen

lagere metaalberoepen

lagere rail- en wegtransportberoepen

lagere hout- en papierberoepen

lagere transportberoepen

lagere horecaberoepen

lagere textielberoepen

lagere voedings- en genotmiddelenberoepen

lagere bouwmaterialen-, glas- en aardewerkberoepen

lagere administratieve beroepen

middelbare commerciele beroepen

middelbare technische, ambachts- en industrieberoepen

lagere technische, ambachts- en industrieberoepen

middelbare horecaberoepen

lagere electrotechnische beroepen

lagere grafische beroepen

middelbare electrotechnische beroepen

lagere chemische beroepen

middelbare lucht- en overige transportberoepen

middelbare medische en paramedische beroepen

$\begin{array}{lrr}4,5 & -5 & -1,7 \\ 4,0 & -17 & -1,6 \\ 3,6 & -20 & -1,4 \\ 3,6 & -24 & -1,4 \\ 2,0 & -16 & -0,8 \\ 1,9 & -9 & -0,8 \\ 1,5 & -17 & -0,6 \\ 1,4 & -8 & -0,5 \\ 1,3 & -11 & -0,5 \\ 1,2 & -20 & -0,5 \\ 1,0 & -16 & -0,4 \\ 0,8 & -15 & -0,3 \\ 0,7 & -16 & -0,3 \\ 0,7 & -9 & -0,3 \\ 0,6 & -8 & -0,3 \\ 0,6 & -7 & -0,2 \\ 0,5 & -13 & -0,2 \\ 0,4 & -8 & -0,1 \\ 0,3 & -14 & -0,1 \\ 0,3 & -16 & -0,1 \\ 0,2 & -13 & -0,1 \\ 0,2 & -12 & -0,1 \\ 0,1 & -9 & -0,1\end{array}$

Mavo, onderbouw HAVOMWO

middelbare administratieve beroepen

middelbare politie-, brandweer- en bewakingsberoepen

lagere agrarische beroepen

lagere verzorgende beroepen

middelbare militaire beroepen

lagere bouw- en installatieberoepen

lagere metaalberoepen

lagere textielberoepen

lagere horecaberoepen

lagere administratieve beroepen

lagere hout- en papierberoepen

lagere voedings- en genotmiddelenberoepen

middelbare horecaberoepen

lagere bouwmaterialen-, glas- en aardewerkberoepen

middelbare electrotechnische beroepen

VBO landbouw en natuurlijke omgeving

lagere agrarische beroepen

\section{VBO bouwtechniek}

lagere hout- en papierberoepen

lagere bouw- en installatieberoepen

lagere metaalberoepen

lagere agrarische beroepen

middelbare administratieve beroepen

lagere bouwmaterialen-, glas- en aardewerkberoepen

lagere verzorgende beroepen

$\begin{array}{lrr}1,5 & -8 & -2,2 \\ 1,4 & -8 & -1,9 \\ 0,2 & -7 & -0,3 \\ 0,2 & -16 & -0,3 \\ 0,2 & -11 & -0,3 \\ 0,1 & -6 & -0,1 \\ 0,1 & -6 & -0,2\end{array}$


Tabel 4.5 (vervolg)

Verwachte krimp-kengetallen opleidingstypen naar beroepssegment, 1995-2000

Baanvernietiging Re

Bijdrage aan

in \%

uitbreidingsvraag krimp

in $\%$

VBO installatietechniek

lagere bouw-en installatieberoepen

VBO mechanische techniek

lagere metaalberoepen

lagere bouw- en installatieberoepen

lagere agrarische beroepen

middelbare administratieve beroepen

lagere hout- en papierberoepen

$\begin{array}{lrl} & & \\ 1,7 & -7 & -2,4 \\ 0,6 & -8 & -0,9 \\ 0,5 & -16 & -0,7 \\ 0,2 & -11 & -0,3 \\ 0,2 & -8 & -0,3 \\ 0,1 & -6 & -0,1 \\ 0,1 & -6 & -0,1 \\ & & \\ 0,6 & -12 & -2,4 \\ 0,2 & -8 & -0,6 \\ 0,2 & -7 & -0,7 \\ 0,1 & -11 & -0,6\end{array}$

beroepen

lagere verzorgende beroepen

VBO motorvoertuigentechniek

middelbare metaalberoepen

lagere bouw- en installatieberoepen

lagere metaalberoepen

middelbare administratieve beroepen

0,1

$-0,6$
$-0,7$

VBO elektrotechniek

middelbare electrotechnische beroepen

lagere metaalberoepen

lagere bouw- en installatieberoepen

middelbare administratieve beroepen

VBO grafische techniek

lagere grafische beroepen

VBO consumptieve techniek

lagere voedings- en genotmiddelenberoepen

VBO textiel- en ledertechniek

middelbare administratieve beroepen

lagere textielberoepen

lagere verzorgende beroepen

\section{VBO haven en vervoer}

VBO administratie

middelbare administratieve beroepen

lagere agrarische beroepen

VBO verkoop en handel

middelbare administratieve beroepen

VBO verzorging

middelbare administratieve beroepen

lagere agrarische beroepen

lagere verzorgende beroepen

lagere textielberoepen

lagere horecaberoepen

middelbare horecaberoepen

lagere administratieve beroepen

$\begin{array}{lrl}0,3 & -11 & -1,9 \\ 1,7 & -11 & -1,7 \\ 1,2 & -16 & -1,2 \\ 1,2 & -6 & -1,2 \\ 0,3 & -12 & -0,3 \\ 0,2 & -2 & -0,2 \\ 0,1 & -4 & -0,1 \\ 0,1 & -7 & -0,1\end{array}$




\begin{tabular}{|c|c|c|c|}
\hline & $\begin{array}{l}\text { Baanvernietiging } \\
\text { in } \%\end{array}$ & $\begin{array}{l}\text { Rel. } \\
\text { uitbreidingsvraag } \\
\text { in } \%\end{array}$ & $\begin{array}{l}\text { Bijdrage aan } \\
\text { krimp }\end{array}$ \\
\hline VBO bewaking & & & \\
\hline $\begin{array}{l}\text { HAVO/VWO bovenbouw } \\
\text { middelbare administratieve beroepen } \\
\text { lagere agrarische beroepen } \\
\text { hogere sociaal-culturele beroepen }\end{array}$ & $\begin{array}{l}1,2 \\
0,1 \\
0,1\end{array}$ & $\begin{array}{l}-2 \\
-8 \\
-2\end{array}$ & $\begin{array}{r}-0,8 \\
-0,1 \\
0,0\end{array}$ \\
\hline $\begin{array}{l}\text { MBO/LLW landbouw en natuurlijke omg } \\
\text { lagere agrarische beroepen }\end{array}$ & eving & -8 & $-4,9$ \\
\hline $\begin{array}{l}\text { MBO technisch laboratorium } \\
-\end{array}$ & - & - & - \\
\hline $\begin{array}{l}\text { MBO/LLW bouwkunde } \\
\text { middelbare bouw- en installatieberoepen } \\
\text { middelbare administratieve beroepen } \\
\text { hogere bouw- en installatieberoepen }\end{array}$ & $\begin{array}{l}0,1 \\
0,1 \\
0,1\end{array}$ & $\begin{array}{l}-3 \\
-2 \\
-5\end{array}$ & $\begin{array}{l}-0,1 \\
-0,1 \\
-0,1\end{array}$ \\
\hline $\begin{array}{l}\text { MBO/LLW weg- en waterbouwkunde } \\
\text { - }\end{array}$ & - & - & - \\
\hline $\begin{array}{l}\text { MBO/LLW metaalkunde } \\
\text { - }\end{array}$ & - & - & - \\
\hline $\begin{array}{l}\text { MBO/LLW fijnmechanische techniek } \\
\text { - }\end{array}$ & - & - & - \\
\hline $\begin{array}{l}\text { MBO/LLW werktuigbouwkunde } \\
\text { middelbare administratieve beroepen }\end{array}$ & 0,1 & -2 & $-0,1$ \\
\hline $\begin{array}{l}\text { MBO/LLW motorvoertuigentechniek } \\
\text { middelbare metaalberoepen }\end{array}$ & 0,3 & -3 & $-0,9$ \\
\hline $\begin{array}{l}\text { MBO/LLW elektrotechniek } \\
\text { middelbare administratieve beroepen }\end{array}$ & 0,1 & -2 & $-0,1$ \\
\hline $\begin{array}{l}\text { MBO/LLW grafische techniek } \\
\text { - }\end{array}$ & - & - & - \\
\hline $\begin{array}{l}\text { MBO/LLW consumptieve techniek } \\
-\end{array}$ & - & - & - \\
\hline $\begin{array}{l}\text { MBO/LLW procestechniek } \\
-\end{array}$ & - & - & - \\
\hline $\begin{array}{l}\text { MBO/LLW textiel- en ledertechniek } \\
\text { lagere textielberoepen } \\
\text { middelbare administratieve beroepen }\end{array}$ & $\begin{array}{l}0,2 \\
0,1\end{array}$ & $\begin{array}{l}-5 \\
-2\end{array}$ & $\begin{array}{l}-0,9 \\
-0,4\end{array}$ \\
\hline $\begin{array}{l}\text { MBO/LLW haven en vervoer } \\
\text { middelbare administratieve beroepen }\end{array}$ & 0,1 & -2 & $-0,4$ \\
\hline $\begin{array}{l}\text { MBO/LLW verpleging en medische ass } \\
\text { middelbare administratieve beroepen } \\
\text { hogere sociaal-culturele beroepen }\end{array}$ & tentie & $\begin{array}{l}-2 \\
-2\end{array}$ & $\begin{array}{l}-0,1 \\
-0,1\end{array}$ \\
\hline
\end{tabular}


Tabel 4.5 (vervolg)

Verwachte krimp-kengetallen opleidingstypen naar beroepssegment, 1995-2000

\begin{tabular}{|c|c|c|c|}
\hline & $\begin{array}{l}\text { Baanvernietiging } \\
\text { in } \%\end{array}$ & $\begin{array}{l}\text { Rel. } \\
\text { uitbreidingsvraag } \\
\text { in \% }\end{array}$ & $\begin{array}{l}\text { Bijdrage aan } \\
\text { krimp }\end{array}$ \\
\hline MBO/LLW medisch laboratorium & - & - & - \\
\hline $\begin{array}{l}\text { MBO/LLW handel } \\
\text { middelbare administratieve beroepen } \\
\text { lagere agrarische beroepen }\end{array}$ & $\begin{array}{l}1,0 \\
0,3\end{array}$ & $\begin{array}{l}-2 \\
-8\end{array}$ & $\begin{array}{l}-0,6 \\
-0,2\end{array}$ \\
\hline $\begin{array}{l}\text { MBO/LLW administratief } \\
\text { middelbare administratieve beroepen }\end{array}$ & 0,7 & -2 & $-1,5$ \\
\hline $\begin{array}{l}\text { MBO toerisme en recreatie } \\
\text { middelbare administratieve beroepen }\end{array}$ & 0,1 & -2 & $-1,6$ \\
\hline $\begin{array}{l}\text { MBO/LLW commercieel } \\
\text { middelbare administratieve beroepen }\end{array}$ & 0,2 & -2 & $-0,9$ \\
\hline $\begin{array}{l}\text { MBO/LLW secretarieel } \\
\text { middelbare administratieve beroepen }\end{array}$ & 0,8 & -2 & $-1,7$ \\
\hline $\begin{array}{l}\text { MBO bestuurlijk-juridisch } \\
\text { middelbare administratieve beroepen } \\
\text { hogere bestuurlijke en juridische beroepen }\end{array}$ & $\begin{array}{l}0,4 \\
0,2\end{array}$ & $\begin{array}{r}-2 \\
-20\end{array}$ & $\begin{array}{l}-1,6 \\
-1,0\end{array}$ \\
\hline $\begin{array}{l}\text { MBO sociaal-cultureel } \\
\text { middelbare administratieve beroepen } \\
\text { hogere sociaal-culturele beroepen }\end{array}$ & $\begin{array}{l}0,2 \\
0,1\end{array}$ & $\begin{array}{l}-2 \\
-2\end{array}$ & $\begin{array}{l}-0,6 \\
-0,5\end{array}$ \\
\hline $\begin{array}{l}\text { MBO/LLW verzorging } \\
\text { middelbare verzorgende beroepen } \\
\text { middelbare administratieve beroepen } \\
\text { lagere agrarische beroepen }\end{array}$ & $\begin{array}{l}0,9 \\
0,3 \\
0,2\end{array}$ & $\begin{array}{r}-10 \\
-2 \\
-8\end{array}$ & $\begin{array}{l}-0,8 \\
-0,3 \\
-0,2\end{array}$ \\
\hline $\begin{array}{l}\text { MBO/LLW horeca en uiterlijke verzorging } \\
\text { middelbare verzorgende beroepen } \\
\text { middelbare administratieve beroepen }\end{array}$ & $\begin{array}{l}0,6 \\
0,1\end{array}$ & $\begin{array}{r}-10 \\
-2\end{array}$ & $\begin{array}{l}-1,9 \\
-0,3\end{array}$ \\
\hline $\begin{array}{l}\text { MBO politie en defensie } \\
\text { middelbare militaire beroepen } \\
\text { middelbare administratieve beroepen }\end{array}$ & $\begin{array}{l}1,7 \\
0,1\end{array}$ & $\begin{array}{r}-27 \\
-2\end{array}$ & $\begin{array}{l}-4,4 \\
-0,2\end{array}$ \\
\hline HBO onderwijs & - & - & - \\
\hline $\begin{array}{l}\text { HBO tolk en vertaler } \\
\text { - }\end{array}$ & - & - & - \\
\hline HBO landbouw en milieukunde & - & - & - \\
\hline HBO technisch laboratorium & - & - & - \\
\hline HBO (weg- en water)bouwkunde & - & - & - \\
\hline
\end{tabular}


Tabel 4.5 (vervolg)

Verwachte krimp-kengetallen opleidingstypen naar beroepssegment, 1995-2000

\begin{tabular}{|c|c|c|c|}
\hline & $\begin{array}{l}\text { Baanvernietiging } \\
\text { in } \%\end{array}$ & $\begin{array}{l}\text { Rel. } \\
\text { uitbreidingsvraag } \\
\text { in \% }\end{array}$ & $\begin{array}{l}\text { Bijdrage aan } \\
\text { krimp }\end{array}$ \\
\hline \multicolumn{4}{|l|}{ HBO werktuigbouwkunde } \\
\hline- & - & - & - \\
\hline \multicolumn{4}{|c|}{ HBO elektrotechniek en technische informatica } \\
\hline- & - & - & - \\
\hline \multicolumn{4}{|l|}{ HBO haven en vervoer } \\
\hline- & - & - & - \\
\hline \multicolumn{4}{|l|}{ HBO medisch laboratorium } \\
\hline- & - & - & - \\
\hline \multicolumn{4}{|l|}{ HBO verpleging en paramedisch } \\
\hline 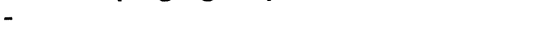 & - & - & - \\
\hline \multicolumn{4}{|l|}{ HBO bedrijfseconomie } \\
\hline- & - & - & - \\
\hline \multicolumn{4}{|l|}{ HBO accountancy } \\
\hline- & - & - & - \\
\hline \multicolumn{4}{|l|}{ HBO bedrijfsinformatica } \\
\hline 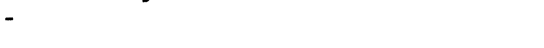 & - & - & - \\
\hline \multicolumn{4}{|l|}{ HBO toerisme en recreatie } \\
\hline (5 & - & - & - \\
\hline \multicolumn{4}{|l|}{ HBO commerciële economie } \\
\hline- & - & - & - \\
\hline \multicolumn{4}{|l|}{ HBO technische bedrijfskunde } \\
\hline (5) & - & - & - \\
\hline $\begin{array}{l}\text { HBO bestuurlijk-juridisch } \\
\text { hogere bestuurlijke en juridische beroepen }\end{array}$ & 0,3 & -11 & $-2,5$ \\
\hline $\begin{array}{l}\text { HBO sociaal-cultureel } \\
\text { hogere bestuurlijke en juridische beroepen }\end{array}$ & 0,2 & -11 & $-0,3$ \\
\hline \multicolumn{4}{|l|}{ HBO kunst } \\
\hline- & - & - & - \\
\hline $\begin{array}{l}\text { HBO politie en defensie } \\
\text { middelbare militaire beroepen }\end{array}$ & 0,3 & -21 & $-7,7$ \\
\hline \multicolumn{4}{|l|}{ WO letteren } \\
\hline - & - & - & - \\
\hline \multicolumn{4}{|l|}{ WO theologisch } \\
\hline- & - & - & - \\
\hline $\begin{array}{l}\text { WO landbouw en milieukunde } \\
\text { - }\end{array}$ & - & - & - \\
\hline
\end{tabular}




\begin{tabular}{|c|c|c|c|}
\hline & $\begin{array}{l}\text { Baanvernietiging } \\
\text { in \% }\end{array}$ & $\begin{array}{l}\text { Rel. } \\
\text { uitbreidingsvraag } \\
\text { in \% }\end{array}$ & $\begin{array}{l}\text { Bijdrage aan } \\
\text { krimp }\end{array}$ \\
\hline WO wiskunde en natuurwetenschappen & 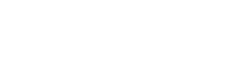 & 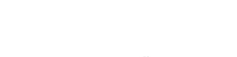 & 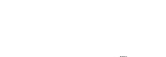 \\
\hline WO (weg- en water)bouwkunde & & & \\
\hline WO werktuigbouwkunde & - & - & - \\
\hline WO elektrotechniek en technische inforn & natica & - & - \\
\hline WO dier-, genees- en tandheelkunde & - & - & - \\
\hline WO farmacie & - & - & - \\
\hline WO econom(etr)ie en accountancy & - & - & - \\
\hline WO bedrijfskunde & - & - & - \\
\hline $\begin{array}{l}\text { WO informatica } \\
\text { - }\end{array}$ & - & - & - \\
\hline $\begin{array}{l}\text { WO juridisch } \\
\text { hogere bestuurlijke en juridische beroepen }\end{array}$ & 0,4 & -3 & $-1,5$ \\
\hline WO bestuurlijk & - & - & - \\
\hline WO sociaal-cultureel & - & - & - \\
\hline WO kunst & - & - & - \\
\hline
\end{tabular}


Tabel 4.6

Percentage werkenden dat tussen 1992-1994 een cursus heeft gevolgd naar opleidingstype

\begin{tabular}{|c|c|c|}
\hline & $\%$ & Typering \\
\hline Basisonderwijs & 17 & laag \\
\hline $\begin{array}{l}\text { Mavo, onderbouw HAVO/MWO } \\
\text { VBO landbouw en natuurlijke omgeving } \\
\text { VBO bouwtechniek } \\
\text { VBO installatietechniek } \\
\text { VBO mechanische techniek } \\
\text { VBO motorvoertuigentechniek } \\
\text { VBO elektrotechniek } \\
\text { VBO grafische techniek } \\
\text { VBO consumptieve techniek } \\
\text { VBO textiel- en ledertechniek } \\
\text { VBO haven en vervoer } \\
\text { VBO administratie } \\
\text { VBO verkoop en handel } \\
\text { VBO verzorging } \\
\text { VBO bewaking }\end{array}$ & $\begin{array}{r}29 \\
13 \\
23 \\
- \\
28 \\
32 \\
23 \\
- \\
13 \\
- \\
- \\
- \\
- \\
-\end{array}$ & $\begin{array}{l}\text { gemiddeld } \\
\text { laag } \\
\text { gemiddeld } \\
\text { gemiddeld } \\
\text { gemiddeld } \\
\text { gemiddeld } \\
\text { gemiddeld } \\
- \\
\text { laag } \\
\text { erg laag } \\
\text { - erg laag } \\
\text { gemiddeld } \\
\text { laag } \\
\text { - }\end{array}$ \\
\hline $\begin{array}{l}\text { HAVO/WWO bovenbouw } \\
\text { MBO/LLW landbouw en natuurlijke omgeving } \\
\text { MBO technisch laboratorium } \\
\text { MBO/LLW bouwkunde } \\
\text { MBO/LLW weg-en waterbouwkunde } \\
\text { MBO/LLW metaalkunde } \\
\text { MBO/LLW fijnmechanische techniek } \\
\text { MBO/LLW werktuigbouwkunde } \\
\text { MBO/LLW motorvoertuigentechniek } \\
\text { MBO/LLW elektrotechniek } \\
\text { MBO/LLW grafische techniek } \\
\text { MBO/LLW consumptieve techniek } \\
\text { MBO/LLW procestechniek } \\
\text { MBO/LLW textiel- en ledertechniek } \\
\text { MBO/LLW haven en vervoer } \\
\text { MBO/LLW verpleging en medische assistentie } \\
\text { MBO/LLW medisch laboratorium } \\
\text { MBO/LLW handel } \\
\text { MBO/LLW administratief } \\
\text { MBO toerisme en recreatie } \\
\text { MBO/LLW commercieel } \\
\text { MBO/LLW secretarieel } \\
\text { MBO bestuurlijk-juridisch } \\
\text { MBO sociaal-cultureel } \\
\text { MBO/LLW verzorging } \\
\text { MBO/LLW horeca en uiterlijke verzorging } \\
\text { MBO politie en defensie }\end{array}$ & $\begin{array}{r}30 \\
30 \\
17 \\
- \\
- \\
- \\
45 \\
- \\
46 \\
- \\
- \\
- \\
- \\
- \\
22 \\
- \\
21 \\
55 \\
- \\
- \\
- \\
- \\
- \\
30 \\
- \\
-\end{array}$ & $\begin{array}{l}\text { gemiddeld } \\
\text { gemiddeld } \\
- \\
\text { laag } \\
- \\
- \\
- \\
\text { hoog } \\
- \\
\text { hoog } \\
- \\
- \\
- \\
- \\
\text { gemiddeld } \\
\text { erg hoog } \\
\text { laag } \\
\text { erg hoog } \\
- \\
\text { hoog } \\
\text { - } \\
\text { gemiddeld } \\
\text { gemiddeld } \\
- \\
\text { erg hoog }\end{array}$ \\
\hline $\begin{array}{l}\text { HBO onderwijs } \\
\text { HBO tolk en vertaler } \\
\text { HBO landbouw en milieukunde } \\
\text { HBO technisch laboratorium } \\
\text { HBO (weg- en water)bouwkunde } \\
\text { HBO werktuigbouwkunde } \\
\text { HBO elektrotechniek en technische informatica } \\
\text { HBO haven en vervoer } \\
\text { HBO medisch laboratorium } \\
\text { HBO verpleging en paramedisch } \\
\text { HBO bedrijfseconomie } \\
\text { HBO accountancy }\end{array}$ & $\begin{array}{r}34 \\
- \\
- \\
- \\
- \\
- \\
- \\
- \\
- \\
48 \\
- \\
-\end{array}$ & $\begin{array}{l}\text { gemiddeld } \\
- \\
\text { gemiddeld } \\
\text { erg laag } \\
\text { gemiddeld } \\
\text { gemiddeld } \\
- \\
\text { erg laag } \\
- \\
\text { hoog } \\
\text { gemiddeld } \\
-\end{array}$ \\
\hline
\end{tabular}


Tabel 4.6 (vervolg)

Percentage werkenden dat tussen 1992-1994 een cursus heeft gevolgd naar opleidingstype

$\%$

Typering

HBO bedrijfsinformatica

HBO toerisme en recreatie

HBO commerciële economie

HBO technische bedrijfskunde

HBO bestuurlijk-juridisch

HBO sociaal-cultureel

HBO kunst

HBO politie en defensie

WO letteren

WO theologisch

WO landbouw en milieukunde

WO wiskunde en natuurwetenschappen

WO (weg- en water)bouwkunde

WO werktuigbouwkunde

WO elektrotechniek en technische informatica

WO dier-, genees- en tandheelkunde

WO farmacie

WO econom(etr)ie en accountancy

WO bedrijfskunde

WO informatica

WO juridisch

WO bestuurlijk

WO sociaal-cultureel

WO kunst

Totaal

28

Bron: OSA/ROA 
Tabel 4.7

Extra bijscholingsbehoefte (gezien de informatiseringsgraad) en extra omscholingsbehoefte (gezien de verwachte werkgelegenheidskrimp en sectorale reallocatie) per opleidingstype

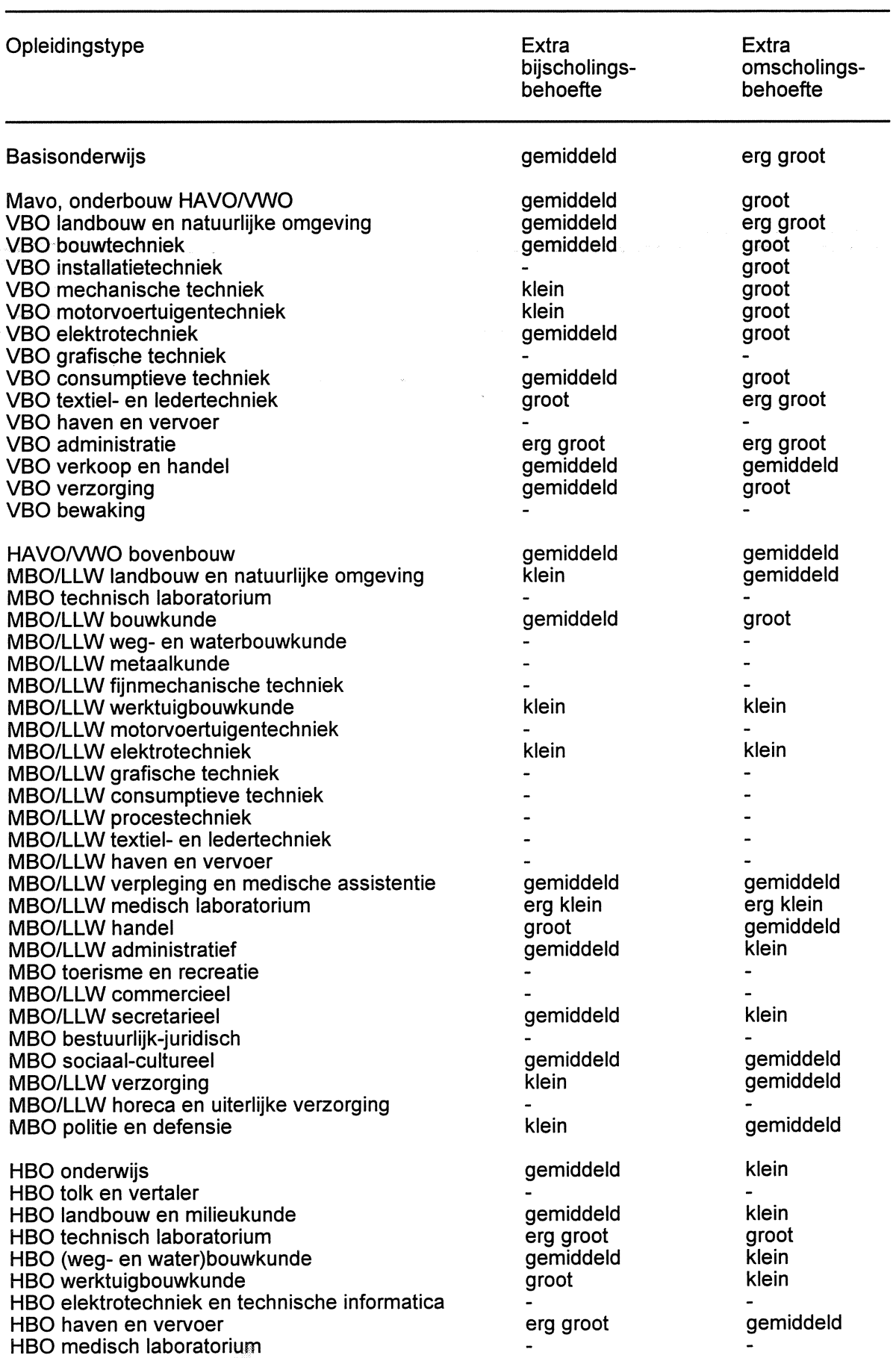


Tabel 4.7 (vervolg)

Extra bijscholingsbehoefte (gezien de informatiseringsgraad) en extra omscholingsbehoefte (gezien de verwachte werkgelegenheidskrimp en sectorale reallocatie) per opleidingstype

\begin{tabular}{|c|c|c|}
\hline Opleidingstype & $\begin{array}{l}\text { Extra } \\
\text { bijscholings- } \\
\text { behoefte }\end{array}$ & $\begin{array}{l}\text { Extra } \\
\text { omscholings- } \\
\text { behoefte }\end{array}$ \\
\hline $\begin{array}{l}\text { HBO verpleging en paramedisch } \\
\text { HBO bedrijfseconomie } \\
\text { HBO accountancy } \\
\text { HBO bedrijfsinformatica } \\
\text { HBO toerisme en recreatie } \\
\text { HBO commerciële economie } \\
\text { HBO technische bedrijfskunde } \\
\text { HBO bestuurlijk-juridisch } \\
\text { HBO sociaal-cultureel } \\
\text { HBO kunst } \\
\text { HBO politie en defensie }\end{array}$ & $\begin{array}{l}\text { erg klein } \\
\text { groot } \\
- \\
- \\
- \\
- \\
- \\
- \\
\text { erg klein } \\
- \\
-\end{array}$ & $\begin{array}{l}\text { erg klein } \\
\text { klein } \\
- \\
- \\
- \\
- \\
- \\
- \\
\text { erg klein } \\
- \\
-\end{array}$ \\
\hline $\begin{array}{l}\text { WO letteren } \\
\text { WO theologisch } \\
\text { WO landbouw en milieukunde } \\
\text { WO wiskunde en natuurwetenschappen } \\
\text { WO (weg- en water)bouwkunde } \\
\text { WO werktuigbouwkunde } \\
\text { WO elektrotechniek en technische informatica } \\
\text { WO dier-, genees- en tandheelkunde } \\
\text { WO farmacie } \\
\text { WO econom(etr)ie en accountancy } \\
\text { WO bedrijfkunde } \\
\text { WO informatica } \\
\text { WO juridisch } \\
\text { WO bestuurlijk } \\
\text { WO sociaal-cultureel } \\
\text { WO kunst }\end{array}$ & $\begin{array}{l}\text { groot } \\
- \\
- \\
\text { gemiddeld } \\
- \\
- \\
- \\
- \\
- \\
- \\
- \\
- \\
- \\
\text { gemiddeld }\end{array}$ & $\begin{array}{l}\text { gemiddeld } \\
- \\
- \\
\text { klein } \\
- \\
- \\
- \\
- \\
- \\
- \\
- \\
- \\
- \\
\text { klein } \\
-\end{array}$ \\
\hline
\end{tabular}

Bron: De Graaf e.a./ROA 
Tabel 4.8

Overzicht van perspectiefrijke omscholingsmogelijkheden naar opleidingstype

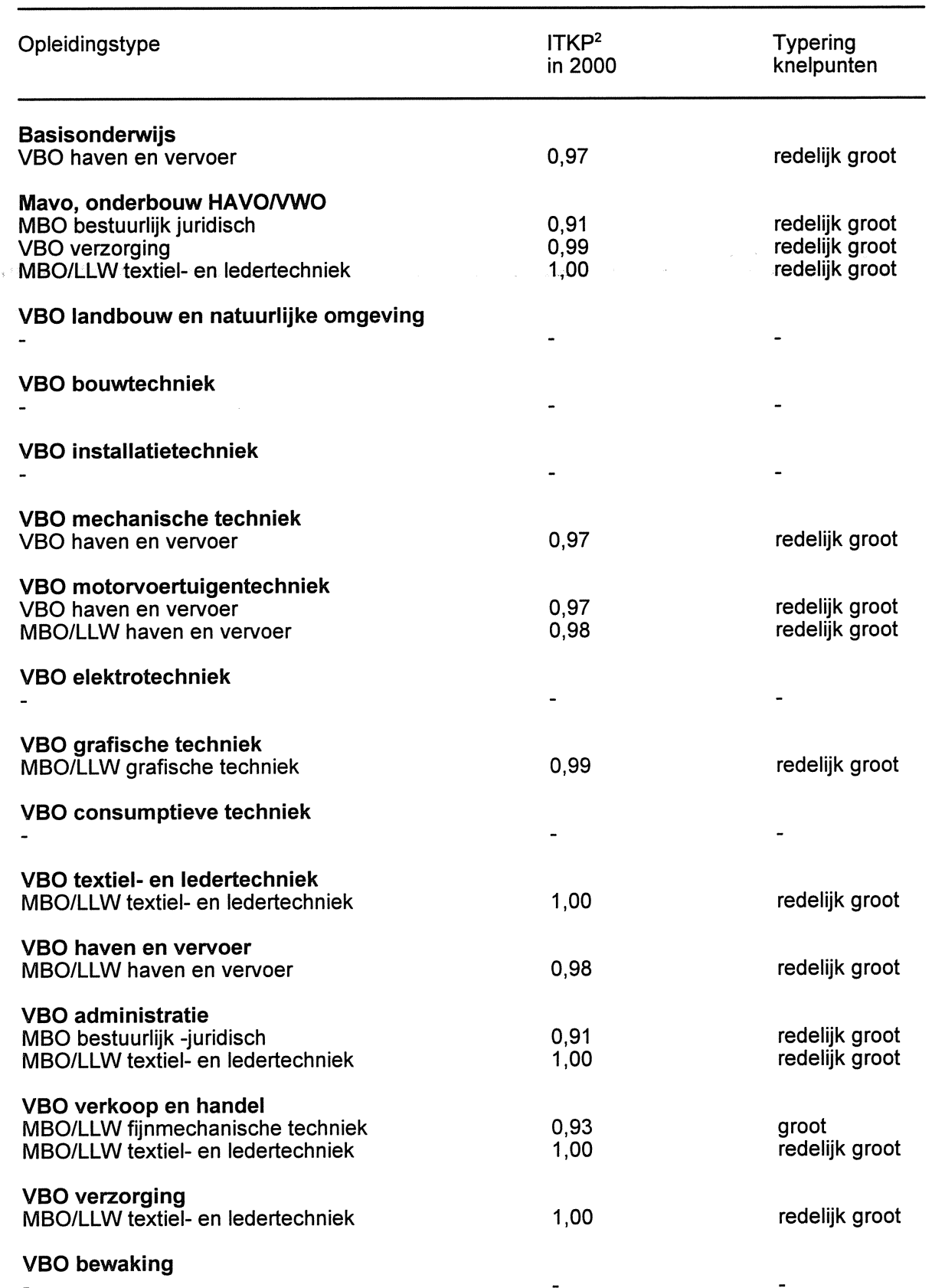

2. Indicator Toekomstige kans op Knelpunten in de Personeelsvoorziening. 
Tabel 4.8 (vervolg)

Overzicht van perspectiefrijke omscholingsmogelijkheden naar opleidingstype

\begin{tabular}{|c|c|c|}
\hline Opleidingstype & $\begin{array}{l}\text { ITKP } \\
\text { in } 2000\end{array}$ & $\begin{array}{l}\text { Typering } \\
\text { knelpunten }\end{array}$ \\
\hline $\begin{array}{l}\text { HAVO/NWO bovenbouw } \\
\text { MBO bestuurlijk-juridisch } \\
\text { MBO/LLW textiel- en ledertechniek }\end{array}$ & $\begin{array}{l}0,91 \\
1,00\end{array}$ & $\begin{array}{l}\text { groot } \\
\text { redelijk groot }\end{array}$ \\
\hline $\begin{array}{l}\text { MBO/LLW landbouw en natuurlijke omgeving } \\
\text { - }\end{array}$ & - & - \\
\hline $\begin{array}{l}\text { MBO technisch laboratorium } \\
\text { HBO technisch laboratorium }\end{array}$ & 0,85 & groot \\
\hline $\begin{array}{l}\text { MBO/LLW bouwkunde } \\
\text { - }\end{array}$ & - & - \\
\hline $\begin{array}{l}\text { MBO/LLW weg-en waterbouwkunde } \\
\text { HBO (weg- en water)bouwkunde }\end{array}$ & 0,83 & groot \\
\hline $\begin{array}{l}\text { MBO/LLW metaalkunde } \\
\text { - }\end{array}$ & - & - \\
\hline $\begin{array}{l}\text { MBO/LLW fijnmechanische techniek } \\
\text { - }\end{array}$ & - & - \\
\hline $\begin{array}{l}\text { MBO/LLW werktuigbouwkunde } \\
\text { - }\end{array}$ & - & - \\
\hline MBO/LLW motorvoertuigentechniek & - & - \\
\hline $\begin{array}{l}\text { MBO/LLW elektrotechniek } \\
\text { - }\end{array}$ & - & - \\
\hline MBO/LLW grafische techniek & - & - \\
\hline $\begin{array}{l}\text { MBO/LLW consumptieve techniek } \\
-\end{array}$ & - & - \\
\hline MBO/LLW procestechniek & - & - \\
\hline $\begin{array}{l}\text { MBO/LLW textiel- en ledertechniek } \\
\text { - }\end{array}$ & - & - \\
\hline $\begin{array}{l}\text { MBO/LLW haven en vervoer } \\
\text { VBO haven en vervoer }\end{array}$ & 0,97 & redelijk groot \\
\hline $\begin{array}{l}\text { MBO/LLW verpleging en medische assistentie } \\
\text { HBO verpleging en paramedisch }\end{array}$ & 0,94 & groot \\
\hline MBO/LLW medisch laboratorium & - & - \\
\hline $\begin{array}{l}\text { MBO/LLW handel } \\
\text { MBO bestuurlijk-juridisch } \\
\text { HBO bestuurlijk-juridisch } \\
\text { MBO/LLW textiel- en ledertechniek }\end{array}$ & $\begin{array}{l}0,91 \\
0,92 \\
1,00\end{array}$ & $\begin{array}{l}\text { groot } \\
\text { groot } \\
\text { redelijk groot }\end{array}$ \\
\hline
\end{tabular}


Tabel 4.8 (vervolg)

Overzicht van perspectiefrijke omscholingsmogelijkheden naar opleidingstype

\begin{tabular}{|c|c|c|}
\hline Opleidingstype & $\begin{array}{l}\text { ITKP } \\
\text { in } 2000\end{array}$ & $\begin{array}{l}\text { Typering } \\
\text { knelpunten }\end{array}$ \\
\hline $\begin{array}{l}\text { MBO/LLW administratief } \\
\text { HBO accountancy } \\
\text { MBO bestuurlijk-juridisch } \\
\text { HBO bestuurlijk-juridisch }\end{array}$ & $\begin{array}{l}0,73 \\
0,91 \\
0,92\end{array}$ & $\begin{array}{l}\text { groot } \\
\text { groot } \\
\text { groot }\end{array}$ \\
\hline $\begin{array}{l}\text { MBO toerisme en recreatie } \\
\text { - }\end{array}$ & - & - \\
\hline $\begin{array}{l}\text { MBO/LLW commercieel } \\
\text { MBO bestuurlijk-juridisch } \\
\text { HBO bestuurlijk-juridisch } \\
\text { MBO/LLW textiel- en ledertechniek }\end{array}$ & $\begin{array}{l}0,91 \\
0,92 \\
1,00\end{array}$ & $\begin{array}{l}\text { groot } \\
\text { groot } \\
\text { redelijk groot }\end{array}$ \\
\hline $\begin{array}{l}\text { MBO/LLW secretarieel } \\
\text { MBO bestuurlijk-juridisch }\end{array}$ & 0,91 & groot \\
\hline $\begin{array}{l}\text { MBO bestuurlijk-juridisch } \\
\text { HBO bestuurlijk-juridisch }\end{array}$ & 0,92 & groot \\
\hline $\begin{array}{l}\text { MBO sociaal-cultureel } \\
\text { HBO sociaal-cultureel }\end{array}$ & 0,99 & redelijk groot \\
\hline MBO/LLW verzorging & - & - \\
\hline $\begin{array}{l}\text { MBO/LLW horeca en uiterlijke verzorging } \\
\text { - }\end{array}$ & - & - \\
\hline $\begin{array}{l}\text { MBO politie en defensie } \\
\text { HBO politie en defensie }\end{array}$ & 0,99 & redelijk groot \\
\hline HBO onderwijs & - & - \\
\hline HBO tolk en vertaler & - & - \\
\hline HBO landbouw en milieukunde & - & - \\
\hline $\begin{array}{l}\text { HBO technisch laboratorium } \\
\text { HBO medisch laboratorium }\end{array}$ & 0,91 & groot \\
\hline $\begin{array}{l}\text { HBO (weg-en water)bouwkunde } \\
\text { WO (weg-en water)bouwkunde }\end{array}$ & 0,76 & groot \\
\hline $\begin{array}{l}\text { HBO werktuigbouwkunde } \\
\text { WO werktuigbouwkunde }\end{array}$ & 1,00 & redelijk groot \\
\hline $\begin{array}{l}\text { HBO elektrotechniek en technische informatica } \\
\text { HBO bedrijsinformatica } \\
\text { WO elektrotechniek en technische informatica } \\
\text { WO informatica }\end{array}$ & $\begin{array}{l}0,77 \\
0,86 \\
0,93\end{array}$ & $\begin{array}{l}\text { groot } \\
\text { groot } \\
\text { groot }\end{array}$ \\
\hline
\end{tabular}

HBO haven en vervoer 
Tabel 4.8 (vervolg)

Overzicht van perspectiefrijke omscholingsmogelijkheden naar opleidingstype

\begin{tabular}{|c|c|c|}
\hline Opleidingstype & $\begin{array}{l}\text { ITKP } \\
\text { in } 2000\end{array}$ & $\begin{array}{l}\text { Typering } \\
\text { knelpunten }\end{array}$ \\
\hline $\begin{array}{l}\text { HBO medisch laboratorium } \\
\text { HBO technisch laboratorium }\end{array}$ & 0,85 & groot \\
\hline $\begin{array}{l}\text { HBO verpleging en paramedisch } \\
\text { MBO/LLW verpleging en medische assistentie }\end{array}$ & 1,00 & redelijk groot \\
\hline $\begin{array}{l}\text { HBO bedrijfseconomie } \\
\text { HBO accountancy } \\
\text { WO econom(etr)ie en accountancy } \\
\text { MBO bestuurlijk-juridisch } \\
\text { HBO bestuurlijk-juridisch }\end{array}$ & $\begin{array}{l}0,73 \\
0,88 \\
0,91 \\
0,92\end{array}$ & $\begin{array}{l}\text { groot } \\
\text { groot } \\
\text { groot } \\
\text { groot }\end{array}$ \\
\hline $\begin{array}{l}\text { HBO accountancy } \\
\text { WO econom(etr)ie en accountancy } \\
\text { WO bestuurlijk } \\
\text { HBO bestuurlijk-juridisch }\end{array}$ & $\begin{array}{l}0,88 \\
0,88 \\
0,92\end{array}$ & $\begin{array}{l}\text { groot } \\
\text { groot } \\
\text { groot }\end{array}$ \\
\hline $\begin{array}{l}\text { HBO bedrijfsinformatica } \\
\text { WO elektrotechniek en technische informatica } \\
\text { WO informatica }\end{array}$ & $\begin{array}{l}0,86 \\
0,93\end{array}$ & $\begin{array}{l}\text { groot } \\
\text { groot }\end{array}$ \\
\hline $\begin{array}{l}\text { HBO toerisme en recreatie } \\
\text { - }\end{array}$ & - & - \\
\hline $\begin{array}{l}\text { HBO commerciële economie } \\
\text { WO econom(etr)ie en accountancy } \\
\text { MBO bestuurlijk-juridisch } \\
\text { HBO bestuurlijk-juridisch } \\
\text { MBO/LLW textiel- en ledertechniek }\end{array}$ & $\begin{array}{l}0,88 \\
0,91 \\
0,92 \\
1,00\end{array}$ & $\begin{array}{l}\text { groot } \\
\text { groot } \\
\text { groot } \\
\text { redelijk groot }\end{array}$ \\
\hline $\begin{array}{l}\text { HBO technische bedrijfskunde } \\
\text { HBO bedrijfsinformatica } \\
\text { WO informatica } \\
\text { HBO elektrotechniek en technische informatica }\end{array}$ & $\begin{array}{l}0,77 \\
0,93 \\
0,94\end{array}$ & $\begin{array}{l}\text { groot } \\
\text { groot } \\
\text { groot }\end{array}$ \\
\hline $\begin{array}{l}\text { HBO bestuurlijk-juridisch } \\
\text { HBO accountancy } \\
\text { WO econom(etr)ie en accountancy } \\
\text { MBO bestuurlijk-juridisch }\end{array}$ & $\begin{array}{l}0,73 \\
0,88 \\
0,91\end{array}$ & $\begin{array}{l}\text { groot } \\
\text { groot } \\
\text { groot }\end{array}$ \\
\hline $\begin{array}{l}\text { HBO sociaal-cultureel } \\
\text { WO sociaal-cultureel }\end{array}$ & 0,97 & redelijk groot \\
\hline HBO kunst & - & - \\
\hline $\begin{array}{l}\text { HBO politie en defensie } \\
\text { MBO politie en defensie }\end{array}$ & 0,95 & groot \\
\hline WO letteren & - & - \\
\hline WO theologisch & - & - \\
\hline WO landbouw en milieukunde & - & - \\
\hline
\end{tabular}


Tabel 4.8 (vervolg

Overzicht van perspectiefrijke omscholingsmogelijkheden naar opleidingstype

\begin{tabular}{|c|c|c|}
\hline Opleidingstype & $\begin{array}{l}\text { ITKP } \\
\text { in } 2000\end{array}$ & $\begin{array}{l}\text { Typering } \\
\text { knelpunten }\end{array}$ \\
\hline WO wiskunde en natuurwetenschappen & - & - \\
\hline $\begin{array}{l}\text { WO (weg- en water)bouwkunde } \\
\text { HBO (weg- en water)bouwkunde }\end{array}$ & 0,83 & groot \\
\hline $\begin{array}{l}\text { WO werktuigbouwkunde } \\
\text { HBO werktuigbouwkunde }\end{array}$ & 0,98 & redelijk groot \\
\hline $\begin{array}{l}\text { WO elektrotechniek en technische informatica } \\
\text { HBO bedrijfsinformatica } \\
\text { WO informatica } \\
\text { HBO elektrotechniek en technische informatica }\end{array}$ & $\begin{array}{l}0,77 \\
0,93 \\
0,94\end{array}$ & $\begin{array}{l}\text { groot } \\
\text { groot } \\
\text { groot }\end{array}$ \\
\hline $\begin{array}{l}\text { WO dier-, genees- en tandheelkunde } \\
\text { - }\end{array}$ & - & - \\
\hline WO farmacie & - & - \\
\hline $\begin{array}{l}\text { WO econom(etr)ie en accountancy } \\
\text { HBO accountancy } \\
\text { WO bestuurlijk } \\
\text { HBO bestuurlijk-juridisch }\end{array}$ & $\begin{array}{l}0,73 \\
0,88 \\
0,92\end{array}$ & $\begin{array}{l}\text { groot } \\
\text { groot } \\
\text { groot }\end{array}$ \\
\hline $\begin{array}{l}\text { WO bedrijfskunde } \\
\text { - }\end{array}$ & - & - \\
\hline $\begin{array}{l}\text { WO informatica } \\
\text { HBO bedrijfsinformatica } \\
\text { WO elektrotechniek en technische informatica } \\
\text { HBO elektrotechniek en technische informatica }\end{array}$ & $\begin{array}{l}0,77 \\
0,86 \\
0,94\end{array}$ & $\begin{array}{l}\text { groot } \\
\text { groot } \\
\text { groot }\end{array}$ \\
\hline $\begin{array}{l}\text { WO juridisch } \\
\text { HBO bestuurlijk-juridisch }\end{array}$ & 0,92 & groot \\
\hline $\begin{array}{l}\text { WO bestuurlijk } \\
\text { HBO accountancy } \\
\text { WO econom(etr)ie en accountancy }\end{array}$ & $\begin{array}{l}0,73 \\
0,88\end{array}$ & $\begin{array}{l}\text { groot } \\
\text { groot }\end{array}$ \\
\hline $\begin{array}{l}\text { WO sociaal-cultureel } \\
\text { HBO sociaal-cultureel }\end{array}$ & 0,99 & redelijk groot \\
\hline WO kunst & - & - \\
\hline
\end{tabular}

Bron: ROA 
RISICOPROFIELEN NAAR OPLEIDING 
$\ldots \ldots$ 
Het risico op verlies van werk naar opleidingstype: hoogste IT-index
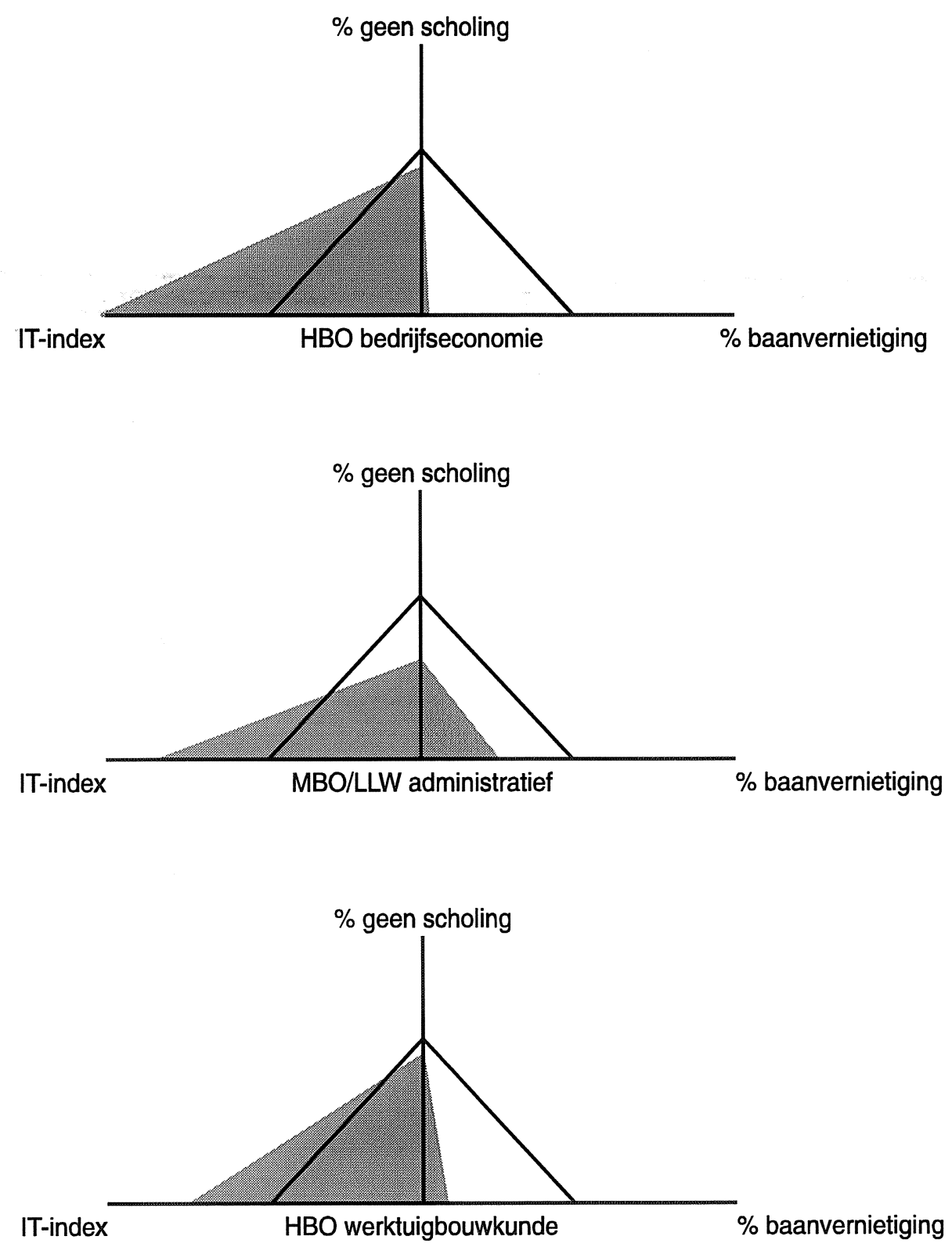

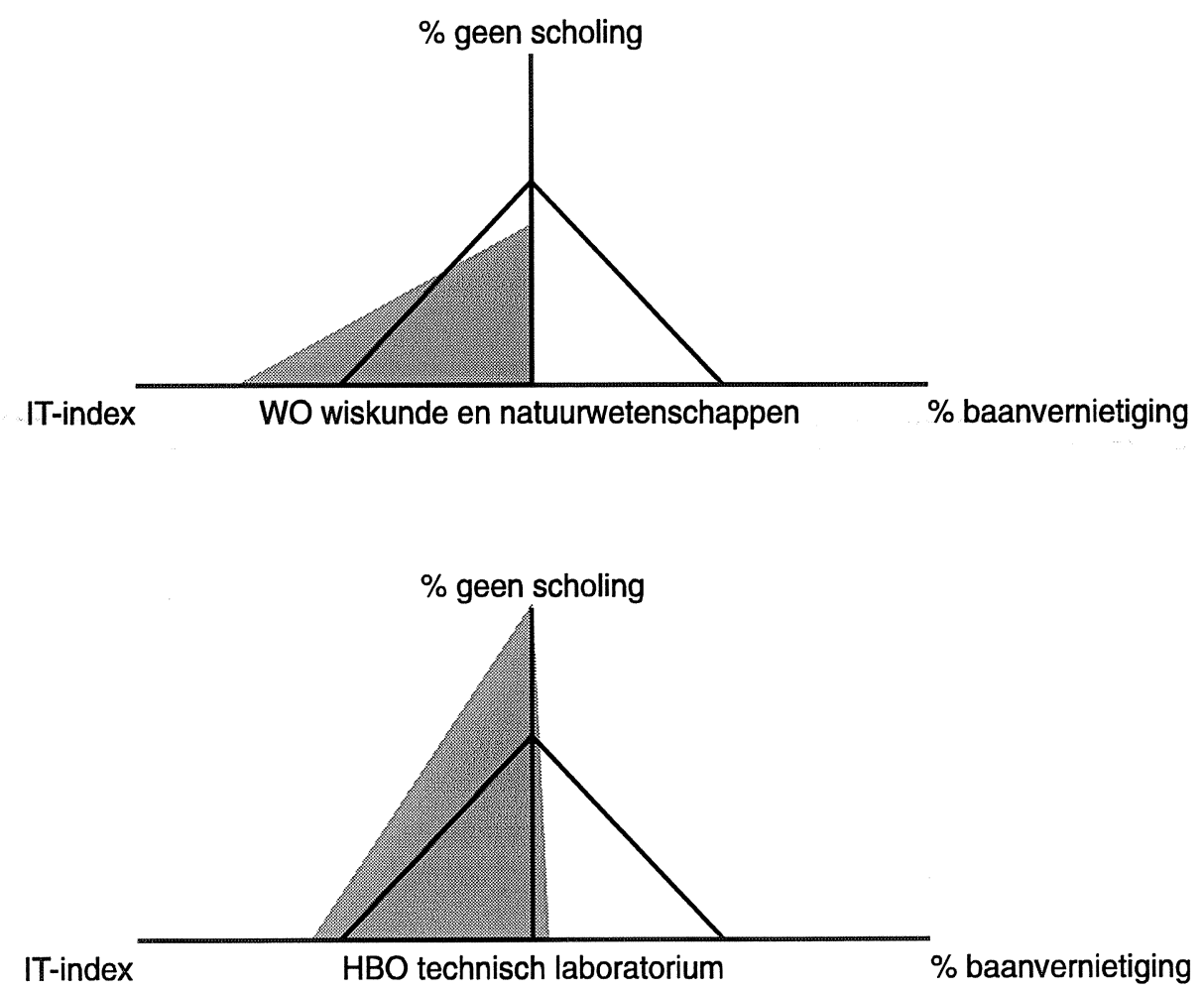
Het risico op verlies van werk naar opleidingstype: hoogste baanvernietiging
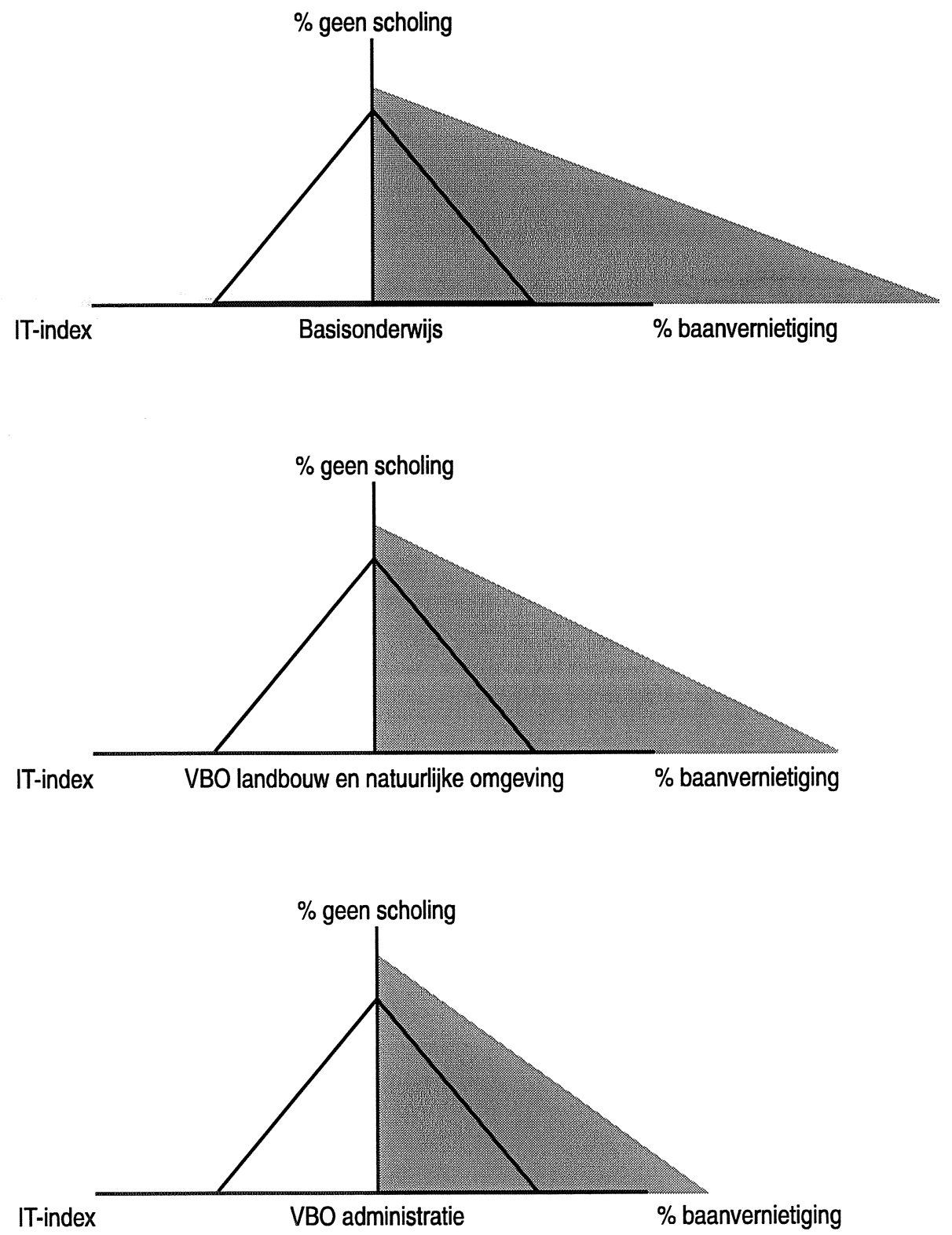

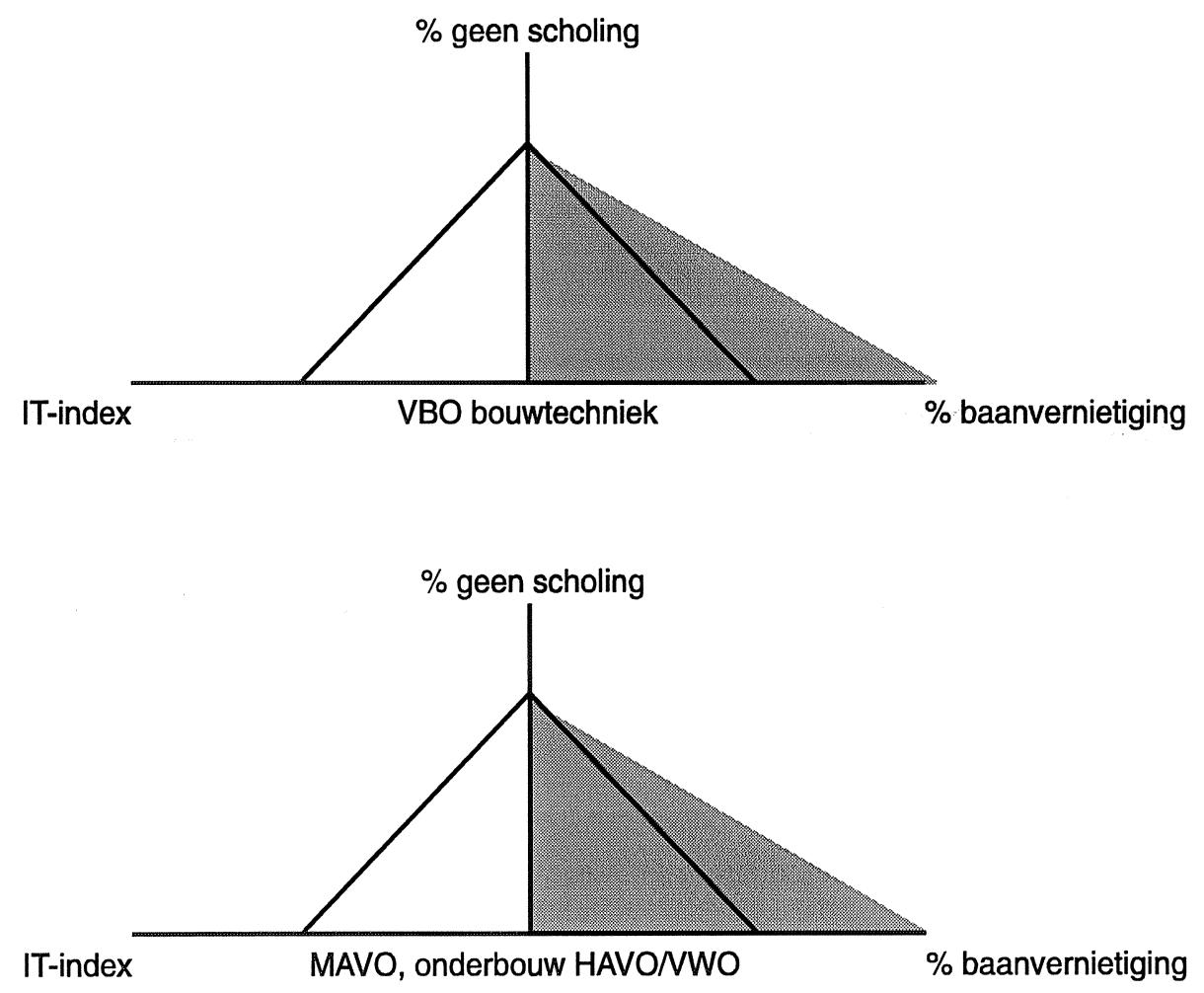
Het risico op verlies van werk naar opleidingstype: hoogste tekort aan scholing
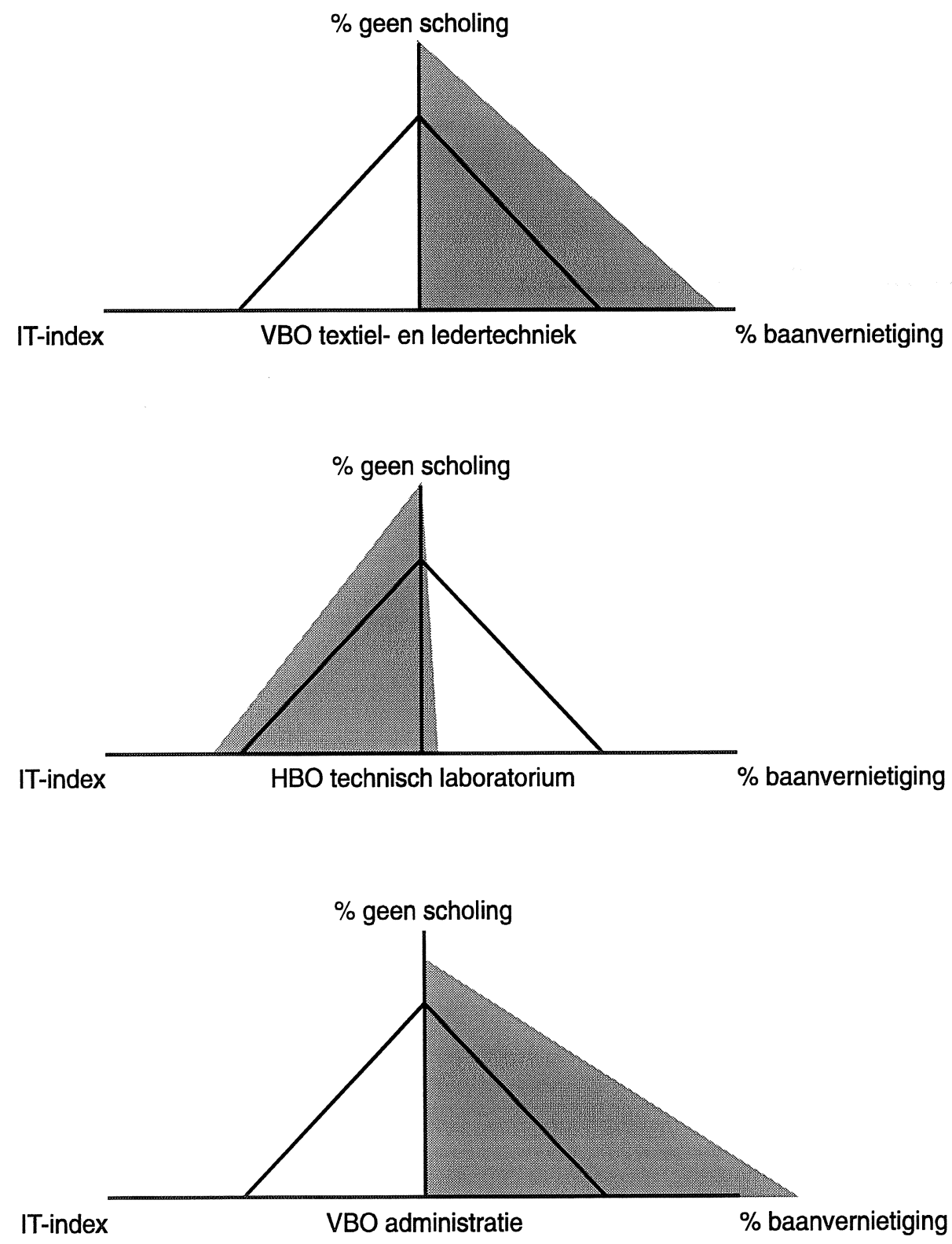

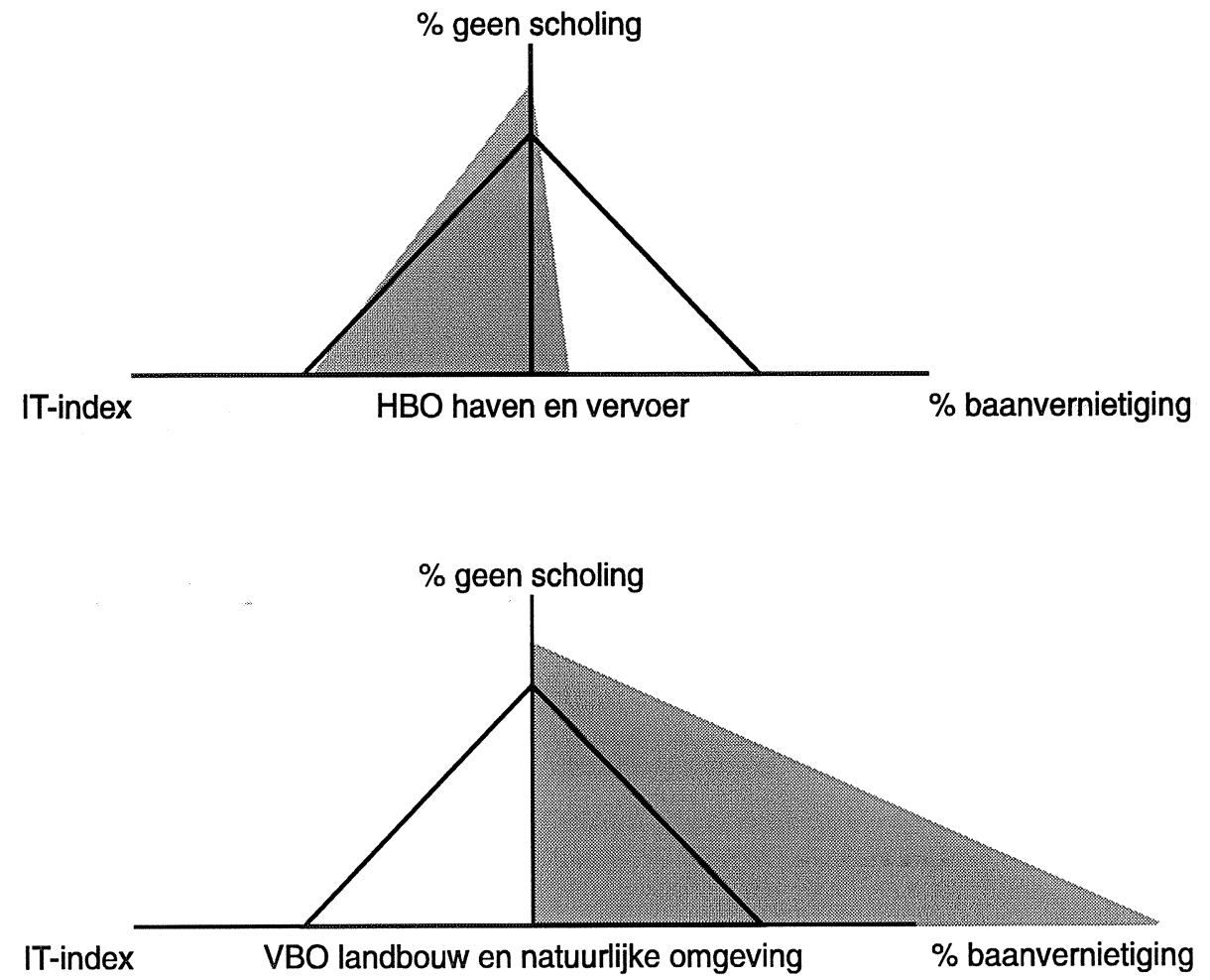